\title{
Integrating pre-clinical skills training in skills laboratory and primary health care centers to prepare medical students for their clerkships
}

Citation for published version (APA):

Widyandana, D. (2011). Integrating pre-clinical skills training in skills laboratory and primary health care centers to prepare medical students for their clerkships. [Doctoral Thesis, Maastricht University]. Maastricht University. https://doi.org/10.26481/dis.20111019dw

Document status and date:

Published: 01/01/2011

DOI:

10.26481/dis.20111019dw

Document Version:

Publisher's PDF, also known as Version of record

Please check the document version of this publication:

- A submitted manuscript is the version of the article upon submission and before peer-review. There can be important differences between the submitted version and the official published version of record.

People interested in the research are advised to contact the author for the final version of the publication, or visit the DOI to the publisher's website.

- The final author version and the galley proof are versions of the publication after peer review.

- The final published version features the final layout of the paper including the volume, issue and page numbers.

Link to publication

\footnotetext{
General rights rights.

- You may freely distribute the URL identifying the publication in the public portal. please follow below link for the End User Agreement:

www.umlib.nl/taverne-license

Take down policy

If you believe that this document breaches copyright please contact us at:

repository@maastrichtuniversity.nl

providing details and we will investigate your claim.
}

Copyright and moral rights for the publications made accessible in the public portal are retained by the authors and/or other copyright owners and it is a condition of accessing publications that users recognise and abide by the legal requirements associated with these

- Users may download and print one copy of any publication from the public portal for the purpose of private study or research.

- You may not further distribute the material or use it for any profit-making activity or commercial gain

If the publication is distributed under the terms of Article 25fa of the Dutch Copyright Act, indicated by the "Taverne" license above, 
INTEGRATING PRE-CLINICAL SKILLS TRAINING IN SKILLS LABORATORY AND PRIMARY HEALTH CARE CENTERS TO PREPARE MEDICAL STUDENTS FOR THEIR CLERKSHIPS 
The research reported here was carried out at

\section{Maastricht University}

in the School of Health Professions Education

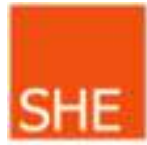

, and

in the Faculty of Medicine, Universitas Gadjah Mada (UGM)

Yogyakarta, Indonesia

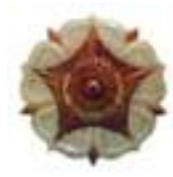

This research was funded by

The Netherlands Programme for Institutional Strengthening of Post-secondary Education and Training Capacity (NPT) Project - NUFFIC NL

\section{nuffic}

(C) Widyandana, Yogyakarta

ISBN 978-602-97622-8-0

Cover Design : Wisnu Birowo

Production: Kelompok Penerbit Tiara Wacana 


\title{
INTEGRATING PRE-CLINICAL SKILLS TRAINING IN SKILLS LABORATORY AND PRIMARY HEALTH CARE CENTERS TO PREPARE MEDICAL STUDENTS FOR THEIR CLERKSHIPS
}

\author{
Dissertation \\ to obtain the degree of Doctor at Maastricht University, \\ on the authority of the Rector Magnificus Prof. Mr. G. P. M. F. Mols, \\ in accordance with the decision of the Board of Deans, \\ to be defended in public on 19 October 2011 at 12.00 hours
}

by

D. Widyandana 
Supervisor (s):

Prof. Dr. A.J.J.A. Scherpbier

Prof. Dr. S. Sastrowijoto

Co-supervisor:

Dr. G.D. Majoor

Assessment Committee:

Prof.dr. C.P.M. van der Vleuten (voorzitter)

Dr. J. van Dalen

Dr. D.H.J.M. Dolmans

Prof.dr. T.L. Dornan

Prof.dr. A.C. Nieuwenhuijzen Kruseman 


\section{Title Paae}

Table of Content

Chapter 1 . General introduction

Published as: Wid yardand D, Majour G, Sc verpbier A. 2010. Tran sfer of medical st udents' clin cal skills learned in a clinical bboratory to the care of real patients in the clinical setting: the th al lenges and sugyestions of students in a devel oping country. Educ Health 23(3):1-6.

Chapter 3 . Selecting an appropriate setting for $E C E$ Published as: Wid ya ndana D, Majour GD, Scherpbier AJJA. 2011. Comparison of three clinica environmerts for pre-cli nical slinical skills training. Med Teach Online: $1-5$. (DO : 10.2109/0142.159X.2011. 558141 .

Chapter 4. Exploring the readiness of patients in PHC centers Submitted as: Widyandana D, Majoor GD, Scherpbier A IIA. Patients' appreciatinn nf are-clinical students' performance in primary hea th care centers in Indoriesid.

Chapter 5. Evaluation by students and supervisors on ECE in PHC centers Published as: Wid yandana D, M ajoor GD, Scherpbier AJJA 2011. Effects of partia substitution of preclinical scills training by attochments to primary health care centers: An experimental stucty. Med Teach २३(6):e21 ₹-237.

Chapter 6. Evaluating the effect of ECE in the fir st clerkships Submitted as: Wi dyanda na D, Majoor GD, 5 cherpbier AJJA. Students' experiences in early cle-ksoips after preparatory attachments to primary health care center 5 : a qual itative 5 tudy.

Chapter 7. General discussion 


\section{Chapter 1.}

GENERAL INTRODUCTION

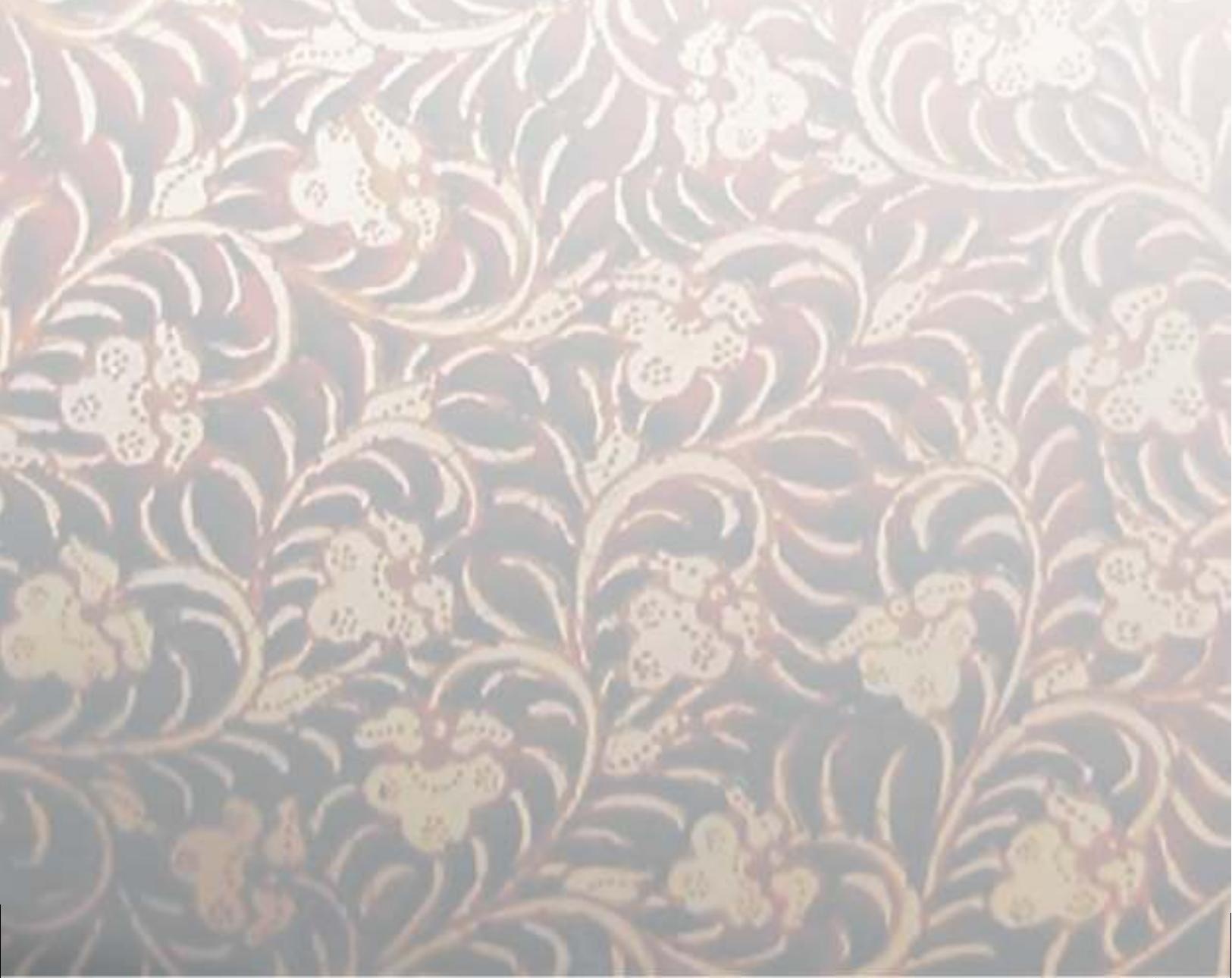




\section{BACKGROUNDAND RATIONALEOF THISSTUDY The context of medical education}

Worldwide, undergraduate medical education is generally divided into two phases: a preclinical and a clinical phase. The preclinical curriculum is generally campus based with structured educational activities, such as lectures, practical sessions, including laboratory and skills training, and small group tutorials. Learning objectives are often specified in a curriculum, designed in accordance with national or international standards, like those of the 'World Federation of Medical Education' (WFME) (2003), the 'General Medical Council' (GMC) in the United Kingdom (2003), and 'Raamplan Artsopleiding' in the Netherlands (van Herwaarden et al. 2009), and Standar Kompetensi Dokter Indonesia (IMC, 2006). These standards specify the medical knowledge, clinical skills, and professional behavior that students must have mastered upon graduation. Many medical schools offer clinical skills training programs, in which students practice in simulated situations which challenge them to also apply their medical knowledge and demonstrate professional behavior. Initially, preclinical students practice with manikins, peers, and simulated patients. During training, students are encouraged to integrate communication skills, physical examination skills, procedural skills, and professional behavior (van Dalen et al. 2001). Skills training is often provided in a skills laboratory, which offers a standardized and safe learning environment. The laboratory is equipped with adequate facilities, such as rooms, medical-equipment, teachers, and simulated patients. Training should help students to achieve an adequate level of competence (encompassing medical knowledge, clinical skills and professional behavior) before they enter the clinical phase of the curriculum (GMC 2003).

During the clinical clerkships of the clinical phase, students learn in clinical settings like primary health care (PHC) centers, secondary health care (SHC) centers (district hospitals), and/or tertiary health care (THC) centers, such as the university hospital. During rotations in various clinical departments students interact with outpatients and with patients on the wards. The clinical phase is usually less structured than the preclinical phase and has some specific limitations. First of all, there are generally no well-defined learning objectives for the clinical phase. Second, since availability of patients and variety of cases is difficult to plan in hospital settings, learning opportunities tend to be rather haphazard. Students' opportunities to practice skills is further limited by the fixed duration of clinical rotations. Furthermore, students may receive too little supervision and feedback from clinical teachers (Spencer 2003). In view of the educational limitations of the clinical phase, it is all the more important that the preclinical phase has given students adequate preparation for clinical training.

\section{The importance of clinical skills training}

Authoritative documents on medical education have emphasized the importance of inclusion of clinical skills training in the preclinical curriculum 
(WFME 2003; GMC 2003). In 2003, the General Medical Council published its position paper 'Tomorrow's Doctors', stating that: "the core curriculum must describe the essential knowledge, skills, and attitudes students must have by the time they graduate." Medical schools design their curricula to ensure that students can reach an adequate level of medical competence to prepare them for real patient encounters during the clinical phase. Students are offered educational activities on campus, such as lectures, tutorials, laboratory practicals, and clinical skill training in a skills laboratory. Apart from its importance for student learning, clinical skills training also has an important contribution to make to patient safety and the quality of health services (Bradley and Postlethwaite 2003).

Preclinical skills training should preferably commence at the start of the preclinical curriculum. It is usually divided into four domains: physical examination skills, procedural skills, laboratory skills, and communication skills (Smith 2006; van Dalen et al. 2001; Nielsen et al. 2003). A longitudinal, integrated, and coherent skills training program running throughout the preclinical phase has been shown to be superior to a brief concentrated program immediately preceding the clinical phase (van Dalen et al. 2001). Longitudinal skills training has been demonstrated to offer students good preparation for patient encounters and to have a positive influence on students' motivation and learning during the preclinical and the clinical phase (Remmen et al. 2001). Skills training has been advocated because it increases students' self-confidence and has a long-term effect on competence, especially with respect to performing clinical skills on patients (Nielsen et al. 2003; Liddell et al. 2002).

\section{Problems with the transition from training in the skills laboratory to training in the clinical setting}

When students transition from the preclinical to the clinical phase, they may face problems when they first have to apply their clinical skills in encounters with real patients. Skills laboratories are not always aware of this hurdle and may fail to prepare students appropriately for this transition (Smith 2006). Moreover, as shown by Hayes et al. (2004), students may suffer from anxiety at this stage, possibly due to low confidence in their ability to perform skills correctly. This anxiety has been demonstrated to be related to students' awareness of the possibility of making mistakes including misdiagnosis and incorrect treatment, which can put patients at risk (Sarikaya et al. 2006). Prince et al. (2005) have shown that in the early stages of clerkships, students may face problems relating to professional socialization and high workload and have difficulty applying their theoretical knowledge to patient cases. The above-mentioned drawbacks of clinical training, such as limited supervision, suboptimal educational environment, limited availability of patients that are suitable for student learning, and students being uncertain as to how they are expected to behave and which activities they are expected to undertake, have been shown to aggravate the "transition problem" for students in their first clinical rotations. 


\section{Context of medical education in Indonesia}

The studies for this thesis were conducted in Indonesia, one of the world's most populous countries. The population, which reached 200 million in 2005 , is dispersed over some 13,000 islands. The diversity of Indonesia's environment and population poses significant challenges to effective health service delivery (Shields and Hartati 2006).

In 1997, Indonesia had over 7,000 health centers and 21,000 health posts. The latter function as first line contact points for patients with the primary health care (PHC) system. For a developing country, PHC is considered the most effective way of ensuring that as many people as possible have access to health care (Barber et al. 2007). The strength of PHC lies in its ability to empower the people whom it serves, for instance by combining health services with education and health promotion. Within this context, the family is the keystone of health care-related decisions. In Indonesia each sub-district (Kecamatan) has at least one primary care community health center, a Puskesmas (Pusat Kesehatan Masyarakat) (Shields and Hartati 2006).

In 2006, the Indonesian Medical Council published a policy document titled: "Standard Competency of Doctors for Indonesia". Soon thereafter the Indonesian Ministry of Education determined that all medical schools in Indonesia should adjust their curricula to the policy described in this document. Consequently, as of 2006, all medical faculties in Indonesia have made a start with the implementation of new curricula in accordance with the standard of the 'Competence-Based Curriculum' $(\mathrm{CBC})$ as advocated in the policy document. The CBC aims to produce graduates who are competent medical doctors that are ready to serve communities at the primary health care (PHC) level. The preclinical phase of the CBC consists of integrated educational units of several weeks ('blocks') focusing on topics that are relevant to professional practice, such as the cardiorespiratory system and the musculoskeletal system. Student centered education was introduced as the main didactic format. Students are stimulated to actively participate in each part of the program by offering them variation in teaching and learning activities, like small group tutorials, clinical skills training, and field activities. The CBC contrasts with the previous curriculum, which was teacher centered and discipline based, implying that professors determined what should be taught in mono-disciplinary courses (e.g. Anatomy, or Internal Medicine). The CBC encompasses a 3.5 year preclinical phase and a 1.5 year clinical phase followed by one year internship in $\mathrm{PHC}$ centers and district hospitals.

Most preclinical educational activities are conducted on campus. They include classroom lectures, small group tutorials, clinical skills training in a skills laboratory, and laboratory practicals. Some additional field activities may also be offered. All activities are expected to be structured, safe, and, as far as possible, organized in relevant settings.

The new clinical phase is very similar to that of the previous curricula, with students training in health care settings, mainly the university teaching 
hospital, district hospitals, and PHC centers. Students undertake clinical rotations in almost all hospital departments (e.g., Internal Medicine, Surgery, Radiology) and in PHC centers. Students learn from their experiences during patient encounters, emergency situations, and health care management. They also learn to collaborate in teams with other health care workers.

After graduating, students are free to enter primary care, specialty training in a clinical discipline, or to pursue other opportunities. As a consequence, it is an ongoing challenge for Indonesian health care to sustain an appropriate physician-tohealth-center ratio in PHC. According to the current policy of the Indonesian government, it is obligatory for medical graduates to work for three years in PHC in remote areas outside the islands of Java and Bali. However, this policy has not been effective in retaining graduates in $\mathrm{PHC}$, because most of them move to the regional capital or other cities for postgraduate training or to practice as soon as they have completed their compulsory service (Barber et al. 2007). Exposure of preclinical students to PHC may motivate more students to pursue a career in PHC (Dornan et al. 2006).

\section{Early clinical experience to bridge the gap between preclinical and clinical training}

Prince et al. (2005) recommended that students should have more patient contacts during the preclinical phase. According to Scavenius et al. (2006) such contacts should be well structured, evolve from simple to more complex patient cases, gradually transfer responsibility to students to increase their ability to apply patient-centered approaches, and provide students with opportunities to interact with other health professionals. Preclinical patient contacts have been shown to enhance students' motivation to learn and reduce stress related to patient contacts early in the clinical phase (Dornan et al. 2006). Early clinical experiences can also be beneficial to teachers, health care centers, individual patients, and communities, because preclinical students will bring to PHC centers their up-to-date knowledge and skills learned on campus, such as professionalism, health education, disease prevention, and patient management (Dornan et al. 2006; Scavenius et al. 2006).

In conclusion, the transition from preclinical to clinical education may be problematic for medical students, particularly early in the clinical phase when they first have to use their clinical skills in patient encounters. Integrating on-campus clinical skills training with training in clinical settings during the preclinical curriculum may be a way to ease the transition from the preclinical to the clinical phase of the undergraduate curriculum.

\section{II.THEAIMSOF THIS DISSERTATION}

The main objective was to seek ways to improve medical students' preparation for clinical training by offering integrated clinical skills training in a skills laboratory and in clinical settings. In order to explore some of the dimensions 
of this goal in the setting of a developing country (Indonesia), the following research questions were addressed:

1. Which problem(s) do medical students encounter during their first clerkships when they have to perform clinical skills learned in the skills laboratory? What remedies do students propose to overcome these problems?

2. Which of the available clinical settings ( $\mathrm{THC}, \mathrm{SHC}$, or $\mathrm{PHC}$ ) is most appropriate for preclinical skills training? How do patients in that setting respond to the presence of students?

3. What is the effect of a combination of skills training in a skills laboratory with training in a clinical environment on students' level of preparedness on entering clinical training?

In order to answer these questions students' transition problems had to be investigated first. Thereafter the possibilities of preclinical skill training in a clinical setting had to be explored as well as the most appropriate clinical setting for that type of training and its effect on students' preparation for the clinical phase. Acceptance of such a training program by patients had to be ascertained as well. The final aim was to arrive at recommendations for an effective skill training program that improved students' preclinical preparation for clinical training and mitigated the transition problems described earlier.

\section{OVERVIEW OFTHECHAPTERS INTHISTHESIS}

Chapter 2, Transfer of medical students' clinical skills learned in a clinical skill laboratory to the care of real patients in the clinical setting: the challenges and suggestions of students in a developing country, explores the problems encountered by students early in the clinical phase when they have to perform clinical skills learned in the skills laboratory in encounters with real patients. The research questions for this study were:

1. How do students perceive their preclinical training in the skills laboratory when they have just started the clinical phase?

2. Which problems do students encounter when they have to transfer skills learned in the skills laboratory to patient care?

3. What suggestions do students make for strengthening the preclinical skills training program?

In an exploratory study, students in the first semester of the clinical phase took part in focus group discussions. The data were analyzed using the 'inductive content analysis protocol', and member checking was conducted to verify the validity of the preliminary results (Fraenkel and Wallen 2009; Elo and Kyngäs 2007).

Chapter 3, Comparison of three clinical environments for pre-clinical clinical skills training, addressed the question which of three clinical settings ( $\mathrm{THC}, \mathrm{SHC}$, or $\mathrm{PHC}$ ) was most appropriate for preclinical medical students to practice their clinical skills. The suitability of clinical settings was explored by examining clerkship students' perceptions of the clinical learning environments and by probing the 
opinions of clinical supervisors. Students' opinions were sampled in the three clinical settings by means of the 'Dundee Ready Education Environment Measure' (DREEM) questionnaire, as designed and validated by Roff et al. (1995); supervisors were interviewed.

Chapter 4, Effects of partial substitution of preclinical skills training by attachments to primary health care centers, describes an experimental study, comparing clinical skills performance and level of preparedness for clerkship of students who had trained exclusively in a skills laboratory and students who had part of their skills training program substituted by training in a PHC centre. Students' level of preparedness for clerkships was measured using the 'Preparation for Hospital Practice Questionnaire' (PHPQ), designed and validated by Hill et al. (1998). This instrument explores students preparedness for clinical training in eight domains (e.g. interpersonal skills, confidence, collaboration). The study also compared the results of the two groups of students on an 'Objective Structured Clinical Examination' (OSCE) (Harden et al. 1975).

Chapter 5, Opinions of patients visiting a Primary Health Care center who were attended by preclinical students. This study explored the opinions of patients in PHC centers who had been attended by preclinical students. Patients' specific comments on the students' clinical skills performance were recorded. Data for the study were collected during structured interviews with outpatients in four PHC centers. The interview scripts were analyzed using the same 'inductive content analysis' protocol that was described in Chapter 2.

In Chapter 6, Students' experiences in early clerkships after preparatory attachments to primary health care centers are described. This study explored differences in early clerkship experiences between students exclusively trained in a skills laboratory and students who had received part of their preclinical skills training in a PHC center. The experiences of the two groups were explored by means of focus group discussions in the students' first semester of clinical training. The transcripts of the focus group sessions were analyzed as described in Chapter 2.

The seventh and final chapter of this dissertation summarizes and discusses the main conclusions from the studies collated in this thesis.

\section{REFERENCES}

Barber SL, Gertler PJ, Harimurti P. 2007. The contribution of human resources for health to the quality of care in Indonesia. Health Aff 26:367-379.

BradleyP, Postlethwaite K. 2003. Setting up a clinical skills learning facility. Med Educ 37:6-13.

Dornan T, Littlewood S, Margolis SA, Scherpbier AJJA, Spencer J, Ypinazar V. 2006. How can experience in clinical and community settings contribute to early medical education? A BEME systematic review. MedTeach 28:3-18.

EloS, Kyngäs H. 2008. The qualitative content analysis process. JAdv Nursing 62:107-115.

Fraenkel JR, Wallen NE. 2009. How to Design and Evaluate Research in Education. 8th edition. New York: McGraw-Hill.

General Medical Council (GMC). 2003. Tomorrow's Doctors. London: General Medical Council.

Harden RM, Stevenson M, Downie WW, Wilson GM. 1975. Assessment of clinical competence using objective structured examination. BrMed J 1:447-451. 
Hayes K, Feather A, Hall A, Sedgwick P, Wannan G, Weisser-Smith A, Green T, McCrorie P. 2004. Anxiety in medical students: is preparation for full time clinical attachments more dependent upon differences maturity or on educational programmes for undergraduate and graduate entry students? Med Educ 38:1154-1163.

Hill J, Rolfe IE, Pearson EA, Heathcote A. 1998. Do junior doctors feel they are prepared for hospital practice? A study of graduates from traditional and nontraditional medical school. Med Educ 32:19-24.

Indonesian Medical Council. 2006. Standar Kompetensi Dokter Indonesia. Jakarta: Indonesian Medical Council.

Liddell MJ, Davidson SK, Taub H, Whitecross LE. 2002. Evaluation on procedural skills training in an undergraduate curriculum. Med Educ 36:1035-1041.

Nielsen DG, Moercke AM, Hansen GW, and Eika B. 2003. Skills Training in Laboratory and Clerkship: Connections, Similarities, and Differences. Med Educ Online 8(12):1-15.

Prince KJAH, Boshuizen HPA, van derVleuten CPM, Scherpbier AJJA. 2005. Students opinions about their preparation for clinical practice. Med Educ 39:704-712.

Remmen R, ScherpbierA, van derVleuten C, Denekens J, Derese A, Hermann I, Hoogenboom R, KramerA, van Rossum H, van Royen P, Bossaert L. 2001. Effectiveness of basic clinical skills training programmes: a cross-sectional comparison of four medical schools. Med Educ 35:121-128.

Roff S, McAleer S, Harden RM, Al-Qahtani M, Ahmed AU, Deza H, Groenen G, Primparyon P. 1997. Development and validation of the Dundee Ready Education Environment Measure (DREEM). MedTeach 19:295-299.

Sarikaya O, Civaner M, Kalaca S. 2006. The anxieties of medical students related to clinical training. J Clin Pract 6o:1414-1418.

Scavenius M, Schmidt S, Klazinga N. 2006. Genesis of the professional-patient relationship in early practical experience: qualitative and quantitative study. Med Educ 40:1037-1044.

Shields LE, and Hartati LE. 2006. Primary Care in Indonesia. J Child Health Care 10(1):4-8.

Smith B. 2006. From simulation to reality-breaking down the barriers. Clin Teach 3: 112-117.

Spencer J. 2003. ABC of learning and teaching in medicine. Learning and teaching in the clinical environment. BrMed J 326:591-594.

Van Dalen J, Bartholomeus P, Kerkhofs E, Lulofs R, Van Thiel J, Rethans JJ, Scherpbier AJJA, Van Der Vleuten CPM. 2001. Teaching and assessing communication skills in Maastricht: the first twenty years. MedTeach 23: 245-251.

Van Herwaarden CLA, Laan RFJM, Leunissen RRM. 2009. Raamplan Artsopleiding 2009. Utrecht: 'Nederlandse Federatie van Universitair Medische Centra'(NFU).

World Federation for Medical Education (WFME). 2003. Basic medical education. WFME Global Standards for Quality Improvement. Copenhagen: World Federation Medical Education. 


\section{Chapter 2.}

\section{Exploring the transition problem}

\section{Publishedas:}

Widyandana D, Majoor G, Scherpbier A. 2010. Transfer of medical students' clinical skills learned in a clinical laboratory to the care of real patients in the clinical setting: the challenges and suggestions of students in a developing country. Educ Health 23 (3):1-6. 


\section{ABSTRACT}

Context: Recent studies indicate that medical students may face problems applying clinical skills taught in a skills laboratory setting when they enter their clerkships. This study explores these problems in the context of a developing country, and explores students' suggestions for improving clinical skills training.

Methods: Focus groups discussions (FGDs) were organized with students who had just entered their clerkships. Transcripts of FGDs were digested according to the inductive content analysis protocol.

Results: Clerkship students said to have encountered significant problems when they had to perform clinical skills on patients for the first time, in particular with respect to invasive clinical procedures. Differences in context between skills laboratory and clinic, inadequate supervision and unpredictable responses by patients were most common reasons given. Students suggested creating opportunities to practice clinical skills on patients before entering the clerkships.

Conclusion: Early in their clerkships students may face significant problems when they have to apply skills learned in the skills laboratory on actual patients. Particularly in developing countries, opportunities may exist to follow up on our students' suggestion to arrange for skills training of pre-clinical students in clinical settings.

Keywords: Clinical skills training, skills laboratory, clerkships 


\section{INTRODUCTION}

Mastery of clinical skills contributes to medical graduates' competence; hence many medical schools have installed facilities for clinical skills training 'skills laboratories'. Skills laboratories offer pre-clinical students opportunities to learn clinical skills in a safe environment and without burdening or endangering patients, with the intention to better prepare students for the clinical years (Smith 2006).

Training within a skills laboratory cannot fully mimic the clinical setting. Consequently, students may encounter problems when they attempt to transfer the clinical skills they learned in the laboratory to the clinical setting (Smith 2006; Sarikaya et al. 2006). More extensive practice in the skills laboratory and exposing students to patients earlier in the curriculum have been suggested for overcoming this problem (Dornan et al. 2006; Diemers et al. 2007).

Most studies addressing this 'transition problem' were performed in industrialized countries (Smith 2006; Sarikaya et al. 2006; Prince et al. 2005). Therefore, this study explored problems encountered by early clerkship students performing clinical skills learned in a skills laboratory, within a single school in a developing country. Research questions were: 1) How do students in their early clerkships regard their pre-clinical trainings in the skills laboratory? 2) What are problems encountered by students when they have to translate the skills they learn in skills labs to the care of actual patients? and 3) What suggestions do students have for strengthening their pre-clinical skills training program?

\section{MATERIALSAND METHODS}

This study was conducted at the Faculty of Medicine of Gadjah Mada University (FM-GMU) in Jogjakarta, Indonesia. FM-GMU has a six-year curriculum encompassing four years of pre-clinical education on campus and two years of clinical rotations at all three levels of health care in Indonesia, i.e. primary care centers, secondary care or district hospitals, and tertiary hospitals servicing provinces.

Focus group discussions (FGDs) were planned with a random sample of 30 fifth year students out of the full class of 162 ; these students had begun their clerkships less than one semester earlier. This subset was found not to differ from the rest of the year class as judged by their scores on the final undergraduate OSCE taken six months earlier (Student t-test; $p=0.615$ ). Students participating in FGDs were assigned to one of three groups that each assembled twice for about 90 minutes. They were reimbursed transportation costs, rewarded with a free lunch, and assured confidentiality with respect to their individual statements. FGDs were guided by three principle questions: "What is your opinion about skills lab training as preparation for your clinical rotations?"; "What problems did you encounter with respect to skills in yourfirst clerkships"; and "How could the problems be solved?" 
Eventually 21 students participated ( 9 females and 12 males). Nine students who did not show up had coincident obligations during their clinical rotations. All sessions were audiotaped and transcribed verbatim. FGD transcripts were analyzed following the 'inductive content analysis protocol' of Elo and Kyngäs (2008). The first author briefed two skills laboratory teachers and a research assistant on the protocol. The protocol includes open coding, creating categories and abstractions. The three coders worked independently in identifying categories, then the lists of categories were grouped within higher order categories to reduce the total number of categories. Eventually a meeting with all four reviewers was held to reach agreement on categories of comments extracted.

The research assistant discussed the final set of categories and illustrative quotes with some individual students drawn randomly from the group of 21 . This checking process was concluded after the fourth student because no new comments on the set of categories and quotes emerged with the third (Fraenkel and Wallen 2009). The protocol for this study was approved by the ethics committee of FM-GMU.

\section{RESULTS}

The coding procedure highlighted 57 statements, which were grouped into three categories and ten sub-categories.

\section{Opinions on the effectiveness of pre-clinical skills training with respect to performance in clerkships}

Clerkship students stated that clinical skills training in the skills laboratory had had a significant positive effect on their preparation for the clerkships; they had found it more difficult to perform clinical skills which had not been taught in the skills laboratory.

"...practice in the skills lab proved very important for me in the clerkships, although I only practiced on manikins and simulated patients. But anything is better than nothing (...)It gave me some confidence." (FGDI/2/1\&3)

However, students perceived skills trainings as a kind of game; they couldn't imagine how skills training related to clinical reality, for instance because there was no risk of harming patients in the skills laboratory. Moreover, for most students the time gap between training in the skills laboratory and entering the clerkship had been over six months, permitting time for newly learned skills to be forgotten. Comments were also made with respect to the management of the skills laboratory, e.g. about instructors from the clinic coming late and about the need to repair or replace certain manikins.

Problems encountered when performing clinical skills on patients for the first time 
Students needed time to adapt to the clinical setting; they did not from the outset feel emotionally ready to meet patients. Students said that the first time they had to apply a clinical skill in the hospital with the stress of the situation, they forgot everything they learned in the skills laboratory.

Students reported that they met many challenges during clinical rotations: an unstructured learning program, an overload of administrative duties, increased responsibility, lack of supervision (by residents and nurses), differences between clinical procedures taught in the skills laboratory and as performed by their supervisors, and differences in equipment used in the skills laboratory and in the clinic.

"...if we do all the steps in accord with the skills lab standard, it will take a long time, and the patient or supervisor may become angry..." (FGDII/1/1;II/2/1;II/3/7)

These circumstances made students anxious when they attended patients for the first time. Students had also noted that communicating with patients was different than exercises performed with peers and simulated patients in the skills laboratory. For example, communication with patients was impeded by patients' local dialect and terminology and their sometimes unexpected responses. In addition, some patients, particularly children and their parents, often did not cooperate.

Clerkship students shared that performing invasive procedures, in particular, caused problems. Students became anxious when the reality of the clinical setting proved to be different from the setting of their training. Differences between manikins used in the skills laboratory and live patients, e.g. varieties in human anatomy and the risk of bleeding, were identified by students as most important in this respect.

"...in the dummy the place to insert the needle is very clear, but with real patients it's so different, we don't know where the blood vessel is..." (FGDI/1/2;II/3/2)

Students became aware that invasive procedures can potentially harm patients, which on one hand enhanced their empathy but also their fear of being prosecuted for malpractice. To prevent the latter, students tried to obtain informed consent from patients before performing procedures. Moreover, students realized that if they would fail to perform an invasive procedure properly it could increase costs for the patient, because the materials used are generally for single use only.

Opinions on opportunities to practice clinical skills during the pre-clinical program in health care settings

To get familiar with applying clinical skills on patients, all participating students welcomed opportunities to practice clinical skills in a health care setting 
prior to entering the clerkships. Some students said such exposures would facilitate transfer of clinical skills from the laboratory to the clinical setting. That statement was based on students' experience in 2006 helping earthquake victims.

"...in the emergency situation after the earthquake we gained experience by helping victims,.......It gave us experience and improved our confidence early in our clerkships..."(FGDI/2/2)

Some students mentioned that training in health care settings may be difficult to implement because such field activities must fit with their tight academic schedule on campus. Furthermore, one student advised that pre-clinical students should only be assigned responsibilities matching their level of competence.

\section{DISCUSSION}

This study finds that the pre-clinical program at FM-GMU does not optimally prepare students to perform clinical skills in their later, clinical rotations. Students found it difficult to apply clinical skills on patients for the first time, and they encountered problems communicating with patients.

These findings are consistent with those from other studies that have found that students have difficulty transferring clinical skills from the pre-clinical to the clinical setting. Students become anxious when it comes to applying clinical skills on patients for the first time (Sarikaya et al. 2006). Moreover, uncertainty about their responsibilities, high work load and inadequate supervision may negatively impact students' performance (Prince et al. 2005). As also noted by Sarikaya et al. (2006), problems encountered with the transfer of clinical skills learned in the skills laboratory to the clinical setting were most prominent with respect to invasive procedural skills.

Some issues emerged in this study that may be specific to developing countries. Manikins that poorly resemble the human body and that may be worn out may negatively affect the effectiveness of training in the skills laboratory. Financial limitations of the country's health insurance system also affected students, because if they failed to successfully perform a procedure involving disposable materials it could increase costs for the patient, who often could not afford it.

To mitigate problems with the transfer of trained clinical skills to the hospital setting, students suggested to include exposure of students to patients within the pre-clinical program. Early patient encounters may provide pre-clinical students with a more accurate picture of the clinical setting and increase their motivation to study (Dornan et al. 2006). Offering such opportunities may particularly be readily available in developing countries where medical schools usually have many primary health centers nearby (Stark and Fortune 2003). Those health centers may be involved in clinical skills training of pre-clinical students (Diemers et al. 2007). 
One study weakness is the small number of participating clerkship students who were confined to only three discussion groups. On the other hand, the findings of the three groups were very similar. A second weakness is that the findings of this study were based on comments from students of only one school and some may reflect the particular situation of students of this school.

In conclusion, pre-clinical skills training may not adequately prepare undergraduate students for performing clinical skills in the hospital setting. Students of this study suggested arranging patient contacts during the pre-clinical phase of their studies to bolster their clinical skills and prepare for interactions with real patients prior to entering the clerkships. In a subsequent study we will explore the suitability of various clinical settings (e.g., primary, secondary and tertiary health care) to offer such opportunities to pre-clinical students.

\section{REFERENCES}

Diemers AD, Dolmans JM, Santen MV, Luijk SJV, Noordman AMBJ, Scherpbier AJJA. 2007. Students perceptions of early patient encounters in a PBL curriculum: a first evaluation of the Maastricht experience. MedTeach 29:135-142.

Dornan T, Littlewood S, Margolis SA, Scherpbier AJJA, Spencer J, YpinazarV. 2006. How can experience in clinical and community settings contribute to early medical education? A BEME systematic review. MedTeach 28:3-18.

EloS, Kyngäs H. 2008. The qualitative content analysis process. JAdv Nursing 62:107-115.

Fraenkel JR, Wallen NE. 2009. How to Design and Evaluate Research in Education. 8th edition. New York: McGraw-Hill.

Prince KJAH, Boshuizen HPA, van derVleuten CPM, Scherpbier AJJA. 2005. Students opinions about their preparation for clinical practice. Med Educ 39:704-712.

Sarikaya O, Civaner M, Kalaca S. 2006. The anxieties of medical students related to clinical training. J Clin Prac 60:1414-1418.

Smith B. 2006. From simulation to reality-breaking down the barriers. Clin Teach 3:112-117.

Stark P, Fortune F. 2003. Teaching clinical skills in developing countries: are clinical skills centres the answer? Educ Health 16:298-306. 


\section{Chapter 3.}

\section{Selecting an appropriate setting for ECE}

Publishedas:

Widyandana D, Majoor GD, Scherpbier AJJA. 2011. Comparison of three clinical environments for pre-clinical clinical skills training. Med Teach Online: 1-5. (DOI:10.3109/0142159X.2011.558141). 


\section{ABSTRACT}

Objectives: Primary health care (PHC), secondary health care (SHC), and tertiary health care (THC) were compared in search of the most suitable setting for clinical skills training of pre-clinical students.

Methods: The Dundee Ready Educational Environment Measure questionnaire was presented to 300 clerkship students of the Faculty of Medicine at Gadjah Mada University, Indonesia who were attached to PHC, SHC, and THC settings. Students were asked to assess their current attachment for suitability for training of preclinical students. Semi-structured interviews were held with 46 clinical supervisors based on the three types of settings.

Results: Clerkship students preferred PHC centers over SHC and THC hospitals for clinical skills training of pre-clinical students $(p<0.05)$. PHC staff felt their centers to be well-equipped to train pre-clinical students, including availability of supervisors' time for teaching, adequate physical facilities and equipment, and suitable patient cases.

Conclusion: In the developing country context, PHC centers seemed more appropriate for clinical skills training of pre-clinical students than SHC and THC hospitals. However, the skills laboratory must guard that clinical skills are trained and performed in the same way in that facility, in PHC centers and in teaching hospitals.

\section{PRACTICE POINTS}

(9HC centers are appropriate for clinical skills training of preclinical students.

Supervisors in PHC may be better equipped to teach pre-clinical students than supervisors in hospitals.

Adequate preparation, e.g., training of supervisors, is needed to assure the quality of the program. 


\section{BACKGROUND}

Nowadays, many medical schools offer their pre-clinical students clinical skills trainings in special facilities often referred to as "skills laboratories." Trainings in such skills laboratories have many advantages including thorough preparation of pre-clinical medical students for participation in clinical clerkships, increasing students' self-confidence, and establishing a long-term effect on students' competencies, particularly for performing clinical skills during their clerkships (Remmen et al. 2001; Liddell et al. 2002; Nielsen et al. 2003).

However, recent studies have shown that students may encounter problems in their early clerkships when they attempt to perform skills learned with manikins on patients, a situation which even can make the students anxious (Sarikaya et al. 2006; Smith 2006). This problem may come on top of other problems which may be met by medical students in their first clerkships like coping with professional socialization, high workload, and the application of theoretical knowledge to patient cases (Prince et al. 2005).

Including training in clinical settings in pre-clinical skills training programs could mitigate some of the problems described above (Smith 2006). Combination of skills laboratory training with training in clinical settings has been demonstrated to yield advantages for students learning (Dornan et al. 2006). To provide combined training in skills labs and clinical settings, medical schools need to select partner clinics for their skills laboratories. Partner clinics could be tertiary health care (THC) centers like university teaching hospitals, secondary health care $(\mathrm{SHC})$ centers like peripheral and district hospitals, or primary health care (PHC) centers (Johnston \& Boohan 2000; O'Sullivan et al. 2000; Claramita \&Widyandana 2008).

\section{AIMS}

To investigate which of these three clinical settings (i.e., $\mathrm{THC}, \mathrm{SHC}$, or $\mathrm{PHC}$ ) is most appropriate for pre-clinical medical students to practice their clinical skills. We will base our assessment of the suitability of clinical settings for pre-clinical skills training on clerkship students' perceptions of their learning environments and opinions of clinical supervisors.

\section{METHODS}

For this study, clerkship students filled in a questionnaire and clinical supervisors were interviewed. A stratified random sample of 300 students of the Faculty of Medicine at Gadjah Mada University (FM-GMU) in Jogjakarta, Indonesia who had entered their clerkships at least 6 months earlier was drawn from all 377 clerkship students of the classes that had commenced their studies in 2004 and 2005. Stratification referred to students' attachment to THC, SHC, or PHC centers. Out of the sample of 300 students, 65 were attached to the main teaching hospital in 
the province (THC), 165 to district hospitals (SHC), and 70 to $\mathrm{PHC}$ centers located in the rural area surrounding the city of Jogjakarta. All PHC centers were public facilities, hosting one or some medical doctors, nurses, midwives, and pharmacists.

Over a 3-month period in 2009, all selected students were visited by a research assistant who asked them to fill in a questionnaire. The introductory letter with the questionnaire explained that this study aimed to assess clinical settings as partners of the skills laboratory to improve FM-GMU's preclinical skills training program. For that purpose, students were asked to rate the setting to which they were attached at that moment. The research assistants guaranteed the students' anonymity and emphasized that participation would not affect the grading of their clinical rotation. Furthermore, students were offered a small reward to promote their participation (Johnson \& Christensen 2008).

The students' survey was performed using the Dundee Ready Educational Environment Measure (DREEM) questionnaire (Roff et al. 1997; Jiffry et al. 2005), which aims to measure appreciation of the learning environment by pre-clinical students. The DREEM questionnaire has been validated and used in several studies (Roff et al. 1997, 2001; Jiffry et al. 2005). This questionnaire encompasses 50 items covering five domains: (students') perception of learning (SPL), perception of teaching (SPT), academic self-perception (SAP), perception of atmosphere (SPA), and social self-perception (SSP). Students are requested to respond to statements on the quality of their learning environment on a 5-point Likert scale on which 4, strongly agree, 3, agree, 2, unsure, 1, disagree, and 0, strongly disagree (Roff et al. 1997; Jiffry et al. 2005).

Data from the DREEM questionnaires were analyzed using Kruskal-Wallis test. This test was applied to assess differences between responses by students residing in the three clinical settings (i.e., THC, SHC, and PHC). Mann-Whitney test was applied to compare scores given by students for each clinical setting (Bryman \& Cramer 2001). Values of $p<0.05$ were taken to indicate statistical significance. Mean scores on sub-scales were divided into four ranges and interpreted as "quality levels" according to Jiffry et al. (2005).

Four research assistants conducted interviews with clinical supervisors. Out of a total of 142 clinical supervisors affiliated with FM-GMU 46 were selected by stratified random sampling. This procedure yielded a sample of 16 supervisors originating from seven departments in one THC centre, 15 from four $\mathrm{SHC}$ centers, and 15 from 32 PHC centers.

Surveyors interviewed the supervisors one on one based on a set of eleven questions (semi-structured interview). The interviewers took written notes during the interviews on forms sub-divided in accord with the questions. Each interview took 20-30 min. At the end of the interview, a small amount of money (approximately US \$5) was handed over to reward the supervisor's cooperation and contribution (Johnson \& Christensen 2008). 
Using the protocol of Johnson and Christensen (2008), three persons separately analyzed the notes on the interviews. The three reviewers were a senior lecturer, a research assistant, and the first author. Initially, the reviewers convened to be informed on the objectives of the study and to be instructed on the coding procedure. Reviewers started with open coding to identify themes, categories, and sub-categories and eventually summarized all codings by reviewers into conclusions. After finishing the coding procedure, the three reviewers met again to build agreement and to check their conclusions with the interviewers.

\section{RESULTS}

Out of the sample of 300 clerkship students, 292 filled in the questionnaire: 66 in PHC, 165 in SHC, and 61 attached to THC settings (response rate: 98\%). Six students refused to participate in the study; two students could not be reached.

Scores given by students based on different clinical settings were significantly different (Kruskal-Wallis test; $\mathrm{p}<0.00, \mathrm{Cl} 95 \%$ ). With only one exception, scores on all five subscales of DREEM were significantly different for the three clinical settings (Mann-Whitney test; $\mathrm{p}<0.05 ; \mathrm{Cl} 95 \%$ ). The exception was the score on SPT between THC and SHC settings $(p=0.136)$. Based on the labeling of DREEM scores by Jiffry et al. (2005), the PHC setting was consistently rated one "quality level" higher than $\mathrm{SHC}$ as well as THC settings on all sub-scales (Table 1 ).

All 46 supervisors included in the sample were interviewed. Comparison of coding outcomes with all coders and interviewers showed no disagreement about content but only some questions about illegible handwriting, abbreviations used by the interviewees, and missing data. These minor problems could be solved by information exchange. Examples of categories extracted from the interviews are presented in Table 2; below the outcomes from the interviews have been summarized.

Almost all supervisors from the three clinical settings would agree to teach pre-clinical students in their institution. In contrast to supervisors in THC and SHC hospitals who do not have scheduled time to teach students, almost all PHC supervisors said to have time allocated to teach students.

"...our time for teaching includes morning discussions from 7.30-8.00 a.m. and afternoon reflections from 11.30-12.30 p.m. In the outpatient clinics and in the wards we can teach the [pre-clinical] students every day one on one with patients..."(PHC-4)

Considering their existing workload, $13 \%$ of the supervisors in $\mathrm{SHC}$ and $1 \%$ in THC explicitly refused to teach pre-clinical students.

"...because the hospital is frequently overloaded with patients we don't have time to teach [pre-clinical] students..."(SHC-3) 
All PHC supervisors agreed to foster students' active learning, whereas most supervisors in hospital settings preferred students just to be observers.

Qualifications of the supervisors in the three settings were significantly different. All PHC supervisors were general practitioners (GPs), most of the SHC supervisors specialists, and most of the THC supervisors sub-specialists. This distribution is related to the kind of patients attended in the three settings. PHC supervisors felt that most patients visiting PHC centers could be managed by GPs, whereas only $64 \%$ of the $\mathrm{SHC}$ supervisors and $50 \%$ of the THC supervisors agreed that the majority of the patients in their respective hospitals could be managed by GPs. One quarter of the THC supervisors and $20 \%$ of the SHC supervisors felt their patients would suffer more from preclinical students' practice than patients in $\mathrm{PHC}$ settings.

"...we have emergency patients, so it's not ethical to have students practicing on them... .... with heart failure patients, they can only observe the treatment..."(THC-1)

In the THC setting, there would be far more competitors in training for preclinical students practice compared with SHC and $\mathrm{PHC}$ settings.

"...we already have lots of residents and clerkship, nursing, and midwifery students here..." (THC-16)

Supervisors from the three settings had comparable expectations with respect to clinical skills training of pre-clinical students, including receiving objectives, guidelines, or elaborated modules with respect to the training program; training on teaching of pre-clinical students; involvement in the planning process; and clear appointments with respect to remuneration by the faculty. Furthermore, supervisors expected the faculty to consider their workload and the training capacity of the institution. They would also expect the faculty to support their facilities and human resources for teaching and learning.

"...for the institution, we need support to create adequate facilities for teaching, and as supervisors we need appropriate rewards, and feedback from the faculty with respect to our teaching ability ... ....we expect to have meetings for preparation and training on supervising and assessing [pre-clinical] students..." (SHC-2)

\section{DISCUSSION}

Clerkship students identified PHC centers as more suitable for practicing clinical skills by pre-clinical students than SHC or THC settings. Almost all clinical supervisors agreed that preclinical students should have clinical experiences to learn to apply their skills on patients. Strong support came in particular from $\mathrm{PHC}$ 
supervisors who also indicated their centers to have adequate facilities and appropriate patient cases for skills training of pre-clinical students.

These findings support introduction of clinical skills training for pre-clinical students in PHC settings as also initiated in several medical institutions elsewhere in the world (Hampshire 1998; Haffling et al. 2001; Diemers et al. 2007). Hampshire (1998) and Worley et al. (2006) have shown that practice at primary care level provides pre-clinical students with opportunities for "hands on practice" on simple patient cases with intensive coaching and feedback by supervisors. PHC environments were particularly recommended for learning about psychosocial issues, which may increase students' awareness of patient autonomy and improve their communication skills (O'Sullivan et al. 2000). This study confirms findings from industrialized countries in the context of a developing country, i.e., Indonesia.

The three clinical settings have their own characteristics with advantages and disadvantages for students' learning (O'Sullivan et al. 2000). During clerkships, students will be confronted with more complex patient cases in more complicated hospital settings. During skills training of pre-clinical students in PHC settings, the skills laboratory should guard that clinical skills are trained and performed in the same way in the skills laboratory, in primary care centers, and in the teaching hospitals.

Some weaknesses of this study must be taken in consideration. The DREEM questionnaire was designed for clerkship students to assess their learning environments (Roff et al. 1997; Jiffry et al. 2005); however, in this study, we asked clerkship students to judge the suitability of their clinical environments for clinical skills training of pre-clinical students. To emphasize this goal, we added clear instructions with the questionnaire about the aim of this study. We assume that the clerkship students for that purpose were able to respond to the questionnaire based on their recent previous experience as pre-clinical students.

PHC supervisors were surprisingly willing and even eager to receive preclinical students in their centers for skills training. Perhaps, projected remuneration by the faculty for supervising these students had an impact in this respect. But, even if this were the case it would not jeopardize chances to realize skills training of preclinical students in PHC settings. Responses by PHC supervisors were in line with findings from other studies stating that GPs in primary care usually provide better clinical supervision to students compared with their hospital-based colleagues (O'Sullivan et al. 2000; Worley et al. 2006).

In subsequent studies, we will implement collaboration between the skills laboratory and PHC centers for clinical skills training of pre-clinical students, and investigate its effectiveness.

\section{CONCLUSIONS}

Compared with SHC and THC hospitals, clerkship students recommended PHC centers as the best setting for clinical skills training of pre-clinical students. 
According to PHC staff, these centers have adequate facilities, appropriate cases, and teaching time available to train pre-clinical students. Collaboration of the skills laboratory with $\mathrm{PHC}, \mathrm{SHC}$, and THC settings is necessary to guard identical application of skills procedures in all settings used for clinical training of students.

\section{ACKNOWLEDEMENTS}

The authors acknowledge Dr. Widya Safitri and Dr. Suwono for collaboration in conducting the survey of clerkship students, Mrs Wardhani Dyah Nurimaniwati for collecting data in PHC settings, and the student research assistants Bina Muntafia Dewintari, Cindarwati, Pande Putu Adhyka, and Adhy Permana for their dedicated work. We also acknowledge the advice of Dr. Anton Sony Wibowo on statistical analyses and of Dr. Santosa Budihardjo on qualitative data analysis. Declaration of interest:The authors report no conflicts of interest. The authors alone are responsible for the content and writing of the article.

\section{REFERENCES}

Bryman A, Cramer D. 2001. Quantitative Data Analysis with SPSS Release 10 for Windows. East Sussex, FA: Routledge.

Claramita M, Widyandana D. 2008. Skills Laboratory. Yogyakarta, Indonesia: Faculty of Medicine Gadjah MadaUniversity Press.

Diemers AD, Dolmans JM, Santen MV, Luijk SJV, Noordman AMBJ, Scherpbier AJJA. 2007. Students perceptions of early patient encounters in a PBL curriculum: A first evaluation of the Maastricht experience. MedTeach 29:135-142.

Dornan T, Littlewood S, Margolis SA, Scherpbier A, Spencer J, Ypinazar V. 2006. How can experience in clinical and community settings contribute to early medical education? A BEME systematic review. MedTeach 28:3-18.

Haffling AC, Hakansson A, Barbro H. 2001. Early patient contact in primary care: A new challenge. Med Educ 35:901-908.

Hampshire AJ. 1998. Providing early clinical experience in primary care. Med Educ 32:495-501.

Jiffry MTM, McAleer S, Fernando S, Marasinghe RB. 2005. Using the DREEM questionnaire to gather baseline information on an evolving medical school in Sri Lanka. MedTeach 27:348-352.

Johnson B, Christensen L. 2008. Educational Research. Quantitative, Qualitative, and Mixed Approaches. 3rded. London, UK: Sage Publication.

Johnston BT, Boohan M. 2000. Basic clinical skills: Don't leave teaching to the teaching hospitals. Med Educ 34:692-699.

Liddell MJ, Davidson SK, Taub H, Whitecross LE. 2002. Evaluation on procedural skills training in an undergraduate curriculum. Med Educ 36:1035-1041.

Nielsen DG, Moercke AM, Hansen GW, Eika B. 2003. Skills Training in Laboratory and Clerkship: Connections, Similarities, and Differences. Med Educ online 8:12.

O'Sullivan M, Martin J, Murray E. 2000. Students' perceptions of the relative advantages and disadvantages of community-based and hospital-based teaching: A qualitative study. Med Educ 34:648-655.

Prince KJAH, Boshuizen HPA, van der Vleuten C, Scherpbier AJJA. 2005. Students opinions about their preparation for clinical practice. Med Educ 39:704-712.

Remmen R, Scherpbier A, van derVleuten C, Denekens J, Derese A, Hermann I, Hoogenboom R, Kramer A, van Rossum $H$, van Royen $P$, et al. 2001. Effectiveness of basic clinical skills training programes: A cross-sectional comparison of four medical schools. Med Educ 35:121-128. 
Roff S, McAleer S, Harden RM, Al-Qahtani M, Ahmed AU, Deza H, Groenen G, Primparyon P. 1997. Development and validation of the Dundee Ready Education Environment Measure (DREEM). MedTeach 19:295-299.

Roff S, McAleer S, Ifere OS, Bhattacharya S. 2001. A global diagnostic tool for measuring educational environment: Comparing Nigeria and Nepal. MedTeach 23:378-382.

Sarikaya O, Civaner M, Kalaca S. 2006. The anxieties of medical students related to clinical training. Jour of Clin Pract 60:1414-1418. Smith B. 2006. From simulation to reality - breaking down the barriers. The Clin Teach 3:112-117.

Worley P, Prideaux D, Strasser R, Magarey A, March R. 2006. Empirical evidence for symbiotic medical education: A comparative analysis of community and tertiary-based programmes. Med Educ 40:109-116. 


\section{APPENDIXES}

Table 1. Scores on the DREEM questionnaire and their interpretation ${ }^{\mathrm{a}}$

\begin{tabular}{|c|c|c|c|c|c|c|}
\hline \multirow[b]{3}{*}{$\begin{array}{l}\text { Sub-scale of } \\
\text { DREEM }\end{array}$} & \multicolumn{6}{|c|}{ Clinical setting } \\
\hline & \multicolumn{2}{|c|}{ PHC } & \multicolumn{2}{|r|}{ SHC } & \multicolumn{2}{|r|}{ THC } \\
\hline & $\begin{array}{l}\text { Mean } \\
\text { (SD) }\end{array}$ & $\begin{array}{l}\text { Interpretation } \\
\text { of DREEM }^{\mathrm{a}}\end{array}$ & $\begin{array}{l}\text { Mean } \\
\text { (SD) }\end{array}$ & $\begin{array}{l}\text { Interpretation } \\
\text { of DREEM }\end{array}$ & $\begin{array}{l}\text { Mean } \\
\text { (SD) }\end{array}$ & $\begin{array}{l}\text { Interpretation } \\
\text { of DREEM }\end{array}$ \\
\hline SPL & $31.66(3.92)$ & $\begin{array}{l}\text { A more positive } \\
\text { approach }\end{array}$ & $21.63(3.98)$ & $\begin{array}{l}\text { Teaching is } \\
\text { viewed negatively }\end{array}$ & $19.70(4.52)$ & $\begin{array}{c}\text { Teaching is } \\
\text { viewed negatively }\end{array}$ \\
\hline SPT & $23.98(2.74)$ & $\begin{array}{l}\text { Moving in the } \\
\text { night direction }\end{array}$ & $19.55^{\prime}(4.27)$ & $\begin{array}{l}\text { In need of } \\
\text { some retraining }\end{array}$ & $18.32^{\prime}(5.07)$ & $\begin{array}{l}\text { In need of } \\
\text { some retraining }\end{array}$ \\
\hline SAP & $21.84(3.47)$ & $\begin{array}{l}\text { Feeling more on } \\
\text { the positive side }\end{array}$ & $13.67(3.09)$ & $\begin{array}{l}\text { Many negative } \\
\text { aspects }\end{array}$ & $12.73(2.75)$ & $\begin{array}{l}\text { Many negative } \\
\text { aspects }\end{array}$ \\
\hline SPA & $31.07(3.60)$ & $\begin{array}{l}\text { A more positive } \\
\text { atmosphere }\end{array}$ & $20.31(4.03)$ & $\begin{array}{l}\text { There are many } \\
\text { issues that } \\
\text { need changing }\end{array}$ & $17.87(5.94)$ & $\begin{array}{l}\text { There are many } \\
\text { issues that } \\
\text { need changing }\end{array}$ \\
\hline SSP & $17.43(2.99)$ & Not too bad & $11.04(2.72)$ & Not a nice place & $9.95(2.38)$ & Not a nice place \\
\hline
\end{tabular}

Notes: according to Jiffry et al. (2005)

Not significantly different $(p=0.136)$; all other scores within sub-scales are significantly different $(p<0.05)$.

Table 2. Examples of outcomes of interviews with clinical supervisors

\section{Coding}

\begin{tabular}{lc}
\hline Themes & $\begin{array}{c}\text { Categories } \\
\text { (selected example) }\end{array}$ \\
\hline
\end{tabular}

Qualifications of superviso

Teaching activities

Case for practice

Competitorsors

Facilities for learning

Suggestions

Expectations
I am a GP

I am a clinical specialist

I am a clinical sub - specialist

I have clear teaching objectives

In my clinical setting, the majority of patients can

be dealt with at the level of general practice

In my clinical setting, there are many competitors

for patients(i.e., the facility is crowded with doctors and students

My clinical setting has adequate space for teaching and learning

I would appreciate training how to teach clinical

skills to pre-clinical students

I require students to be adequately prepared prior to

them practicing in my institution

I would expect to receive guidelines or modules for teaching

I would expect to receive clear learning objectives from the faculty
Percent supervisors

PHC SHC THC

(N=15)

$(\mathrm{N}=15)$

$(\mathrm{N}=15)$

$\begin{array}{rrr}100 & 20 & 20 \\ 0 & 80 & 19 \\ 0 & 0 & 81 \\ 87 & 36 & 19 \\ 100 & 64 & 50 \\ 13 & 40 & 100 \\ & & \\ 03 & 80 & 75 \\ 80 & 40 & 60 \\ 20 & 67 & 69 \\ & & \\ 60 & 67 & 40 \\ 33 & 47 & 56\end{array}$




\section{Chapter 4.}

\section{Exploring the readiness of patients in PHC centers}

Submitted as:

Widyandana D, Majoor GD, Scherpbier AJJA. Patients' appreciation of pre-clinical students' performance in primary health care centers in Indonesia 


\section{ABSTRACT}

Introduction: In Indonesia, primary health care (PHC) centers are among the eligible institutions to provide 'early clinical experiences' (ECE) for pre-clinical medical students.

Objective: To explore whether patients of PHC centers would accept third year preclinical students practicing clinical skills with them.

Methods: Immediately after being seen by a pre-clinical student - supervised by a general physician -76 patients of $\mathrm{PHC}$ centers were subjected to a structured, eightquestion interview. Interviews were transcribed verbatim and coded to collate various answers to the questions.

Results: Most of the patients proved to be satisfied with the clinical performance of their pre-clinical student. Negative comments on some students addressed lack of confidence, being nervous, unable to provide satisfactory explanation and education, and failure to speak the local language. Some patients suggested more practice for these students in $\mathrm{PHC}$ centers.

Conclusion: Patients in Indonesian PHC centers generally appreciated health services provided by pre-clinical medical students; no significant objections were recorded. This adds to the suitability of these PHC centers to offer ECE for pre-clinical students.

Keywords: primary health care centers, clinical skills, pre-clinical students/bachelor

\section{PRACTICE POINTS}

Patients of PHC centers appreciated their involvement in education of preclinical medical students. Their finding adds to the suitability of PHC centers to provide ECE 


\section{INTRODUCTION}

Medical curricula are usually divided in two phases: a pre-clinical phase or bachelor program of three or four years, and a clinical phase (master program) built from clinical rotations commonly spanning two years. During the pre-clinical phase students' learning predominantly takes place on campus, through classroom lectures, small group tutorials, practicals, and often also through clinical skills training in a 'skills laboratory'. The junction between the two phases of these medical curricula confronts the students with a transition from theory-orientated learning on campus to meeting patients and health professionals in the context of health services (Nielsen et al. 2003; Widyandana et al. 2010). Recent studies have shown this transition may bring significant problems for students. Students may feel anxious in their first clinical rotations when they face their first patients in the clinical environment. Such anxieties are most likely caused by differences between campus and skills laboratory settings and clinical reality such as physical facilities, technologies, patients, workload and the expectations of teachers and clinical supervisors, respectively (Prince et al. 2005; Smith 2006; Sarikaya et al. 2006; Widyandana et al. 2010).

Inclusion of early clinical experiences (ECE) in the pre-clinical curriculum has been proposed to improve preparation of pre-clinical students for the clinical phase and to reduce transition problems on entering the clinical rotations (Dornan et al. 2006). ECE should accelerate the development of tacit knowledge (e.g. illness scripts, clinical pattern recognition) as the basis to clinical expertise (Bleakley and Bligh 2006). Moreover, ECE may improve students' familiarity with the roles of patients and health professionals in health care centers and will show them differences between procedures as taught for instance in the skills laboratory and as performed in clinical practice (Dornan et al. 2006). Particularly in developing countries differences between simulations on campus and reality in $\mathrm{PHC}$ centers can be large because of the limited facilities and lack of adequate human resources in these centers. This situation could be different in industrialized countries where PHC centers are usually well-equipped (Spencer 2000; Widyandana et al. 2010).

For the implementation of ECE in the pre-clinical curriculum one of the options for a medical school is to establish cooperation with PHC centers. Several studies have shown that $\mathrm{PHC}$ centers can provide adequate opportunities for students to become actively involved in health care, including interactions with patients and communities, to practice their clinical skills (Worley et al. 2004; Mainhard et al. 2004; Dornan et al. 2007). However, most of these studies were conducted in industrialized countries. There are some reports on ECE implemented in developing countries, for example from Nigeria (Skinner et al. 2008), and from Uganda (Macnab et al. 2010). Furthermore, two papers have described ECE for preclinical students in PHC settings in Indonesia (Kristina et al. 2006; Widyandana et al. 2010). Given the size of that country (over 200 million people dispersed over more than 13,000 islands) Indonesia has adopted the World Health Organization's 
recommendation to focus on PHC as the most effective way to provide adequate health care for all people (Shields and Hartati 2006). Therefore, in Indonesia it seems highly appropriate to involve PHC centers in offering ECE for pre-clinical students.

Obviously, pre-clinical students still have limited medical knowledge and clinical skills. ECE should consider the student's level of competency in order not to jeopardize the safety and optimal treatment of patients. Consequently, during ECE clinical supervisors should exert close supervision of, and provide extensive feedback to the pre-clinical students (Vincent and Coulter 2007).

Wherever ECE is conducted the position and role of the patient should be taken into consideration (Howe and Anderson 2003; Haffling and Hakansson 2008). Patients' opinions on their involvement in longitudinal clinical community-based programs integrated in four-year curricula have been assessed (Cooke et al. 1996; Coleman and Murray 2002; Benson et al. 2005). In these studies in general patients stated to appreciate their involvement in education of medical students; to be satisfied with those students' performance; that students did not disturb regular health services; and that students sometimes even improved health services, possibly because they (can) take more time to give explanation in the consultation (Coleman and Murray 2002; Benson et al. 2005; Haffling and Hakansson 2008). Patients' critical comments included their expectation that students should always be supervised by clinicians; that the latter should explain the educational context and seek patient's permission to involve a student in the consultation; and that confidentiality should be respected by students and supervisors alike. These comments derived particularly from situations in which gender differences may easily cause embarrassment and anxiety with patients and students, for example in case of physical examination of sex organs (Coleman and Murray 2002; Benson et al. 2005; Howe and Anderson 2006). The studies quoted were performed with students who were quite advanced in their studies, and in the context of industrialized, "western" countries. In ECE as envisaged by the Faculty of Medicine at Gadjah Mada University (FM-GMU) in Indonesia, patients would encounter third year pre-clinical students. Moreover, the context of a developing country located in South-East Asia may yield divergent outcomes due to differences in culture (e.g., interaction between males and females), financing and organization of the health care system (e.g., fee-for-service model, no gate-keeping role for by family doctors).

Therefore, the objective of this study is to explore whether patients of PHC centers in Indonesia would accept, welcome or reject their involvement in training of pre-clinical students. To that aim outpatients of PHC centers were interviewed immediately after being seen by pre-clinical students - under supervision of a general physician. Interviews focused on patient opinion on their student's clinical competence and performance. 


\section{METHODS}

In 2010, forty pre-clinical students were randomly selected from FM-GMU's third year class of 186 students and assigned to five PHC centers in the vicinity of the Faculty. At the assigned center, each student met with two outpatients, one male and one female. PHC supervisors applied 'convenience sampling' to select patients from new or revisiting outpatients, based on their suitability to be seen by pre-clinical students (Fraenkel and Wallen 2009). Prior to the consultation, the supervisor explained the patient the setting of the consultation and aim of the subsequent interview and asked the patient's oral consent. Supervised by a general physician (GP) from the PHC center, in each consultation students were instructed to perform anamnesis and (if indicated) physical examination, diagnostic and therapeutic procedures, and patient education with respect to therapy and lifestyle.

Immediately after the consultation each patient was interviewed by a research assistant in a private room. Interviews were conducted within 20 min using a structured guideline with eight questions and recorded on audiotape and by written notes (Litchman 2006). Questions explored patients' opinions on their student's clinical competence and skills performance. Clinical skills performance addressed communication skills (e.g., history taking, problem exploration), physical examination, and diagnostic and therapeutic procedures (if performed), and patient education (e.g., explanation on disease etiology, preventive measures, and treatment). After the interview, patients received a small souvenir (value equaling approx. US \$ 5.-) from FM-GMU in reward for their participation. The study had received prior "ethical clearance" from the pertinent FM-GMU committee.

Interview recordings were transcribed verbatim by research assistants and coded by three individuals: the first author, a senior clinical supervisor, and a research assistant. The first author briefed the other two coders about the protocol, i.e., to code elements of answers to each question, to group and count similar elements, and to choose characteristic quotations. This procedure was conducted independently by each coder. Eventually a meeting of all three coders was held to build consensus on the best collation of the outcomes (Fraenkel and Wallen 2009).

\section{RESULTS}

Thirty-eight pre-clinical students (17 male, 21 female) participated in this study (two students could not attend). Consequently, 76 patients ( 38 females, 38 males) were interviewed after being seen by the 38 participating students.

Distribution of patient ages showed $17 \%$ of them to be children (usually accompanied by parent(s), 54\% adults, and 29\% elderly (over 50 years). Education levels of patients were as follows: $3 \%$ had not received any education, $5 \%$ only kindergarten, $30 \%$ had completed elementary school, $18 \%$ junior high school, $25 \%$ senior high school, and $5 \%$ had attended university ( $14 \%$ of the patients did 
not respond to this question). Most patients were in a low socio-economic stratum (e.g., student, housewife, retired government employee or jobless).

Patients cooperatively participated in this study: only two patients beyond the 86 patients participating refused because they were in a hurry. Interview outcomes are presented in Table 1, in which for each question the five most frequently coded elements of answers are shown.

Patients were overall satisfied with the performance of the students. Most patients had a positive impression of their student's clinical skills performance and judged their student as nice, caring, and able to provide good health service. Patients stated 12 times that students' performance was similar to that of a doctor (i.e., GP). On the other hand, patients commented negatively when their student was unconfident, nervous, or unable to provide satisfactory explanation and education.

"...[the pre-clinical student was] polite, [their clinical skills performance was] already good, their service was like [that provided by a] usual doctor,..." (P.II-M.28)

"...student's examination [anamnesis, physical examination] took too long, [the student] seemed uncertain and confused..." (P.IV-F.57)

Patients generally felt students' communication skills were good and considered the students nice, able to explore their health problem completely, and able to express themselves understandably. However, some patients regretted that their student had difficulty to speak the local language (i.e. Javanese). With respect to physical examination, patients also had a positive impression of their student's performance; and some felt students paid more attention to details than the GP.

\section{"...[the student performed] physical examination well, acted like a real doctor..."(P.III-M.41)}

Diagnostic and therapeutic procedural skills were rarely performed, because most patients reporting to the $\mathrm{PHC}$ center presented quite simple problems which did not require procedures like electrocardiography, wound suturing or urethral catheterization. Therefore, only 23 patients had the opportunity to witness a student performing a diagnostic or therapeutic procedure. According to those patients, students' execution of that procedure was good, although six patients reported their student to seem unconfident.

Patients' opinions on their student's health education skills varied. Fifty-five percent of the patients judged the student's performance in this domain as good, clear, and complete. On the other hand, $45 \%$ of the patients indicated not to be satisfied with the student's performance because the student's explanation had been incomplete or did not fully meet the patient's needs. 
"...there should be more education [to a patient], because I was only told to drink more water and to eat more fruits and vegetables. There should also be education regarding daily activities..."(P.IV-M.55)

In this regard, patients did realize that these pre-clinical students were still in the middle of their studies and consequently still had theoretical weaknesses and lack of clinical experience. Therefore, some recommended students to have more opportunities to practice under close supervision, for instance in PHC centers.

\section{"... he [my student] was good, paid respect,.......[however, he would need] more practice, study more in PHC centers..."(P.I-M.8)}

\section{DISCUSSION}

Patients of Indonesian PHC centers responded positively to their interaction with pre-clinical students. In general patients were satisfied with their student's clinical performance including communication, physical examination, diagnostic and therapeutic skills, and health education. This is quite surprising given the very limited clinical experiences of these students which is largely based on their training in the school's skills laboratory. However, our findings are akin to those from studies performed for example in Europe (Coleman and Murray 2002; Benson et al. 2005; Haffling and Hakansson 2008).

Particularly in developing countries, the presence of students in PHC centers may improve health services, because PHC centers situated there usually have only limited resources. Medical students may expand the center's human resources and boost its functioning by introduction of new techniques (Kristina et al. 2006). Introduction of medical students in PHC centers benefits all stakeholders involved i.e. 1) the PHC center which can provide better services with the help of students; 2 ) the patients who are more extensively attended to; 3 ) the students who receive an opportunity to practice their clinical skills; and 4) the (GP) supervisors whose medical knowledge may be updated while educating the students (Dornan et al. 2006; Widyandana et al. 2010). Obviously, the contribution of pre-clinical students to the functionary of PHC centers may be less significant than those of more senior students, and pre-clinical students need intense and prolonged supervision still, their training in the PHC centers is expected to yield a positive effect on the provision of health services.

Although the majority of the $\mathrm{PHC}$ patients belonged to low economic and educational strata they appreciated to contribute to medical education, they accepted their role in the educational process and proved able to recognize weaknesses in student's performance. Most negative comments by patients on students' performance pertained to confidence and communication skills rather than to physical examination, diagnostic and therapeutic skills. Patients noted when students were unconfident during the encounter. Patients judged their student's 
level of medical knowledge based on the depth or breadth of the student's exploration of their health complaint, and exclusiveness explanation on etiology, prevention and therapy of their disorder. Patients who witnessed students performing physical examination and diagnostic and therapeutic procedures obviously could not give extensive comments on the student's clinical skills performance, because these patients lack the medical knowledge that would allow them to evaluate a student's performance in that respect. Therefore, clinical supervisors remain fully responsible to provide supervision to safeguard adequate service for the patient and to provide feedback to the student with respect to his or her clinical performance.

These findings are similar to those of Coleman and Murray (2002) who showed that patients were pleased to be involved in medical education, as long as the educational institution assured their privacy (consent and confidentiality), they were not harmed, and the educational experience for the students was adequately supervised. Safety and satisfaction of the patients should be prioritized in this program to ensure its success and continuity. Moreover, the clinical supervisor should be able to convince patients that being involved in this education process is also advantageous to them, because they may be examined more extensively and receive more explanation about their disorder (Howe and Anderson 2006; Vincent and Coulter 2007).

A limitation of this study is that it only involved pre-clinical students from one medical school who encountered PHC patients. Students from other medical schools with different skills training programmes may elicit different responses from patients. However, previous studies from other medical schools worldwide yielded results comparable to those presented here (Coleman and Murray 2002; Benson et al. 2005; Haffling and Hakansson 2008; Skinner et al. 2008; Macnab et al. 2010).). Therefore, we assume our findings to be applicable in a variety of countries, including developing ones.

Another limitation is that the data of this study are only based on opinions of patients, and did not include those of supervisors and pre-clinical students. However, in another study we investigated opinions of students and their supervisors (Widyandana et al. 2011).

In a further study, an attempt could be made to improve the effectiveness of this ECE program by selecting patients whose complaints require the students to perform clinical skills which they learned in their previous skills training. Moreover, patients could also be requested to give feedback on the student's clinical performance after encounter (Howe and Anderson 2006).

\section{CONCLUSION}

Patients in Indonesian PHC centers accepted to be seen by pre-clinical medical students supervised by a GP from the center. Although these patients were from low socio-economic and educational strata they were able to recognize weaknesses in the students' clinical performance. Particularly medical schools in developing 
Icountries should explore possibilities to involve PHC centers in offering ECE to preclinical students.

\section{ACKNOWLEDGEMENTS}

The authors acknowledge Dr. Bambang Djarwoto and Ms. Bina Muntafia Dewintari for their help with qualitative data analysis. We are grateful to Mrs. Dany Lukita Sari and several student assistants for data collection in PHC centers. We express our gratitude to the skills laboratory of FM-GMU, the PHC centers and their clinical supervisors for cooperating in this study.

\section{REFERENCES}

Benson J, Quince T, Hibble A, Fanshawe T, Emery J. 2005. Impact on patients of expanded, general practice based, student teaching: observational and qualitative study. Br Med J331(89):1-6.

Bleakley A, Bligh J. 2006. Students learning from patients: let's get real in medical education. Adv Health SciEduc 13(1):89-107.

Coleman A, Murray E. 2002. Patients' views and feelings on community-based teaching of undergraduate medical students: a qualitative study. Fam Prac 19:183-188.

Cooke F, Galascko G, Ramrakha V, Richards D, Rose A, Watkins J. 1996. Medical students in general practice: How do patients feel? Br J Gen Prac 46:361-362.

Dornan T, Littlewood S, Margolis SA, Scherpbier A, Spencer J, Ypinazar V. 2006. How can experience in clinical and community settings contribute to early medical education? A BEME systematic review. MedTeach 28:3-18.

Fraenkel JR, and Wallen NE. 2009. How to design and evaluate research in education. 8th edition. New York: McGraw-Hill.

Haffling AC, Hakansson A, Barbro H. 2001. Early patient contact in primary care: a new challenge. Med Educ 35:901-908.

Howe A, Anderson J. 2003. Involving patients in medical education. Br Med J 327:326-328.

Kristina TN, Majoor GD, Van der Vleuten CPM. 2006. Does community-based education come close to what it should be? A case study from the developing world: students' opinions. Educ Health 19(2):179-188

Litchman M. 2006. Qualitative research in education: a user guide. London: Sage publications.

Macnab AJ, Radziminski N, Budden H, Kasangaki A, Zavuga R, Gagnon FA, Mbabali M. 2010. Brighter smiles Africa - translation of a Canadian community-based health-promoting school program to Uganda. Educ for Health 23(2):1-8.

Mainhard MT, van den Hurk MM, van de Wiel MWJ, Crebolder HFMJ, Scherpbier AJJA. 2004. Learning in a clinical education program in primary care: the Maastricht adoption program. Med Educ 38:12361243.

Murray E, Jolly B, Modell M. 1999. A comparison of the educational opportunities on junior medical attachments in general practice and in a teaching hospital: a questionaire survey. Med Educ 33:170176.

Nielsen, DG, Moercke AM, Hansen GW, Eika B. 2003. Skills training in laboratory and clerkship: connections, similarities, and differences. Med Educ online 8(12):1-15.

Prince KJAH, Boshuizen HPA, van der Vleuten CPM, Scherpbier AJJA. 2005. Students opinions about their preparation for clinical practice. Med Educ 39:704-712.

Sarikaya O, Civaner M, Kalaca S. 2006. The anxieties of medical students related to clinical training. J Clin Prac 60:1414-1418.

Shields LE, and Hartati LE. 2006. Primary care in Indonesia. J Child Health Care 10 (1):4-8.

Smith B. 2006. From simulation to reality-breaking down the barriers. Clin Teach 3:112-117.

Skinner HDE, Onoka CA, Ofoebgu EN. 2008. Community-based education in Nigerian medical schools: students' perspectives. Educ for Health 21(2):1-12. 
Spencer J, Blackmore D, Heard S, McCrorie P, McHafre D, Scherpbier A, Gupta TS, Singh K, Southgate L. 2000. Patient-oriented learning: a review of the role of the patient in the education of medical students. Med Educ 34:851-857.

Vincent CA, CoulterA. 2002. Patient safety: what about the patient? Qual Saf Health Care 11:76-80.

Widyandana D, Majoor G, Scherpbier A. 2010. Transfer of medical students' clinical skills learned in a clinical laboratory to the care of real patients in the clinical setting: the challenges and suggestions of students in a developing country. Educ for Health 23(3):339.

Widyandana D, Majoor GD, Scherpbier AJJA. 2011. Comparison of three clinical environments for preclinical clinical skills training. MedTeach. Early online. DOI:10.3109/0142159X.2011.558141.

Worley P, Prideaux D, Strasser R, Magarey A, March R. 2006. Empirical evidence for symbiotic medical education: a comparative analysis of community and tertiary-based programmes. Med Educ 40:109-116. 


\section{APPENDIX :}

Table 1. Elements from answers to questions (only five most frequently coded shown)

\section{Answer}

Number

(\%)

What did you likejwhat advantages did you encounter with the predinical students? $(\mathrm{n}=\mathbf{1 5 7})$

Thestudentị was nice

$60(3804)$

i...) cared for me

$23\left(15^{6}\right)$

i...) provided good heslth sewices

$\left.20(1)^{5}\right)$

(...) pefformed detail $\rightleftharpoons$ amiration

17 (119:)

No sperific comment

$1 ;(9 ; 9)$

What did you not fiker what di sadvantages did you encounter with the pre-dinical students? $(n=48)$

Nothing/ Nane

$25(52 \%)$

The sbudents) wasuncon fident

.....j did not prowide enough explanation (olucation)

$12(25 \%)$

$4(89)$

$1(8 \%)$

:...) was ner'sus

What is your opinion about the student's exploration of your health compla int? \{ $n-145$ \}

Good

Emyathetc

Extensise exploration

Jear communication

The student vos suncor fident

What is your opinion about the student's physical examination skills? infe110

sood

Extensive

Watched mybealth complaint

Tooseperficial

3̈tsfying

What is your opirion ahout the student's diagenost and therapeutir

skills? (if performed) ( $n=88$ )

Not serformed 
Fid encisid.

Prikrmedsystematically

The student socmed uncorrfident

What is your opirion bast the studerit's medcal lanowiedge when

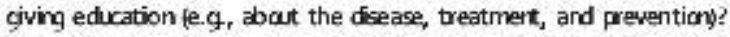
( $\mathrm{r}=113$ )

Good

Torisur

Enainh

Clear

11,1039

More extersive than sovided by $G$ ?

What are your suquedions $f o r$ the pre-ci ricalstudents? (n=52)

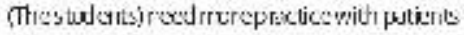

$-4{ }^{\prime} 27 \%$

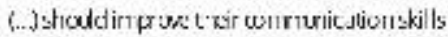

(...) ताए drtaky gxul

(...) jeed to improve theirclinical skils

Nothingi None

Do you tave any other renwers related to the trairing of pre-dinical studerits in the PHC center? (n=32)

Ni

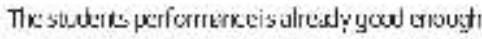

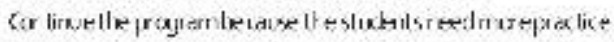




\section{Chapter 5 .}

\section{Evaluation by students and supervisors}

\section{of ECE in PHC centers}

\section{Published as:}

Widyandana D, Majoor GD, Scherpbier AJJA. 2011. Effects of partial substitution of pre-clinical skills training by attachments to primary health care centers: An experimental study. MedTeach 33(6):e313-337. 


\section{ABSTRACT}

Background: Recent studies indicate that students may encounter problems when they have to apply clinical skills learned in a skills laboratory to patients. To facilitate this transition, it has been advised to include patient contacts early in the pre-clinical curriculum.

Objective: To compare clinical skills performance and level of preparedness for entering the clerkships between students who were prepared exclusively in a skills laboratory and peers for whom part of their skills training program was substituted by training in a primary health care $(\mathrm{PHC})$ center.

Methods: Pre-clinical students either trained clinical skills exclusively in a skills laboratory while their peers attended a mixed program of laboratory trainings and practice in PHC centers. Students' perception of preparedness for the clerkships was explored through the Preparation for Hospital Practice Questionnaire. Students' clinical skills were assessed by an Objective Structured Clinical Examination (OSCE) and by supervisors in PHC centers.

Results: Students following the mixed program felt better prepared for their clerkships than skills lab-trained peers. Students' perceptions were supported by assessments by their supervisors. However, mean OSCE scores of both groups did not differ significantly.

Conclusion: PHC centers can be involved to better prepare pre-clinical students for their clerkships.

\section{PRACTICE POINTS}

9 Pre-clinical students who participated in a mixed program of skills training in a skills laboratory and PHC settings felt better prepared for theirclerkships than peers exclusively trained in a skills laboratory

Supervisors in PHCs confirmed students' progress during their practice in PHC.

In this study, OSCE scores of both groups did not show a significant difference. 


\section{INTRODUCTION}

In many medical schools all over the world, clinical skills training is offered to preclinical students in facilities called skills laboratories. Skills laboratories usually avail of manikins, medical equipment and simulated patients to train students' clinical skills (Van Dalen et al. 2001; Smith 2006). A systematic review by Lynagh et al. (2007) has confirmed that clinical skills performance of medical students improves by skills training in skills laboratories.

On the other hand, several studies have indicated that students may encounter problems with the transition of skills learned in the skills laboratory to the hospital setting (Lynagh et al. 2007). Obviously, the clinical environment is very different from the skills laboratory setting. Skills laboratory staff is fully devoted to education, whereas hospital staff will prioritize patient care over teaching. Moreover, training with manikins and simulated patients cannot fully mimic hospital practice, and experiences gained in the laboratory setting may be neglected by the students in clinical contacts with patients (Nielsen et al. 2003; Smith 2006). The resulting "clinical culture shock" may negatively impact on students' motivation for learning (Prince et al. 2005).

Therefore, medical students should be given opportunities to meet patients in the pre-clinical curriculum (Prince et al. 2005; Dornan et al. 2006). Such "early clinical experiences" may promote the learning behavior of pre-clinical students by exposing them to clinical role models, improving their clinical skills, and eventually reducing the stress of meeting patients (Dornan et al. 2006). Early clinical experiences have been shown to give students more confidence to interact with patients in their first clerkships (Hampshire 1998; Smith 2006).

Primary health care $(\mathrm{PHC})$ settings are often involved in education of medical students and students may prefer practicing in $\mathrm{PHC}$ centers over training in teaching hospitals (Hampshire 1998; Haffling et al. 2001). PHC centers provide first line health services to communities and may offer adequate learning facilities for medical students. PHC centers can adequately show students health problems which are common in the community (O'Sullivan et al. 2000; Worley et al. 2006).

The objective of this study was to compare students' level of preparedness to enter the clerkships and clinical skills performance between students who received clinical skills training exclusively in a skills laboratory and peers for whom part of their skills training program was substituted by training in $\mathrm{PHC}$ centers.

\section{METHODS \\ Design of the study}

This study was conducted with a class of 193 fourth year preclinical students of the Faculty of Medicine at Gadjah Mada University (FM-GMU) in Jogjakarta, Indonesia. 
All pre-clinical students of the school participate from the beginning of their studies once or twice a week in a clinical skills training program, which is integrated in the curriculum. Trainings are held in a skills laboratory allocated on the Faculty's campus. Students practice in small groups of eight to ten students, supervised by a skills instructor who can be a general practitioner (GP) or a medical specialist. Students practice in the skills laboratory on manikins, with peers, and with simulated patients. Skills laboratory trainings are designed in accordance with Indonesia's national standard of medical competency which is oriented on cases which are common in the community, like acute respiratory tract infection, diarrhea, and muscular pain. Moreover, students can arrange for 2 -h supervisor-independent practice sessions in the skills laboratory, facilitated by skills laboratory assistants. Skills laboratory assistants are senior medical students trained by skills laboratory supervisors to facilitate their peers' training in accord with the standards prescribed by the skills laboratory. Based on their individual needs, in such sessions, students can practice skills selected by them as often as they wish. On average, an individual student arranges for 5.4 supervisor-independent practice sessions peryear.

Randomly, a sample of 59 students was drawn from the class. This group (designated primary care trained, PT) followed the same instructional program as their 134 peers (not primary care trained, NPT), but for PT students practical trainings with in skills laboratory assistants were substituted with trainings in PHC centers, with a student assistant from the skills laboratory and under supervision of GPs. Eleven PHC centers hosted groups of five or six students each for 11 days over a 5week period. PT students assisted in providing health services, patient management, and health promotion in communities. Moreover, they interviewed health workers and wrote reports and reflections.

Students in NPT and PT groups had comparable opportunities to practice their clinical skills. NPT students practiced in the skills laboratory under safe and structured conditions supervised by GPs or medical specialists, but did not meet with real patients. PT students practiced in $\mathrm{PHC}$ and met with real patients supervised by GPs; however, in this setting, skills training depends on the availability and variety of patients.

\section{Assessing students' preparedness to enter the clerkships}

Students in both PT and NPT groups filled in the "Preparation for Hospital Practice Questionnaire" (PHPQ) which consists of 41 questions on 8 domains: interpersonal skills, confidence, collaboration, management, science, prevention, holistic care, and self-directed learning (Hill et al. 1998). These authors defined the eight domains as follows. Interpersonal skills refer to effective and competent communication with patients; confidence to skills to cope with uncertainty; collaboration to the importance of a team approach to care; management to efficient patient management and performance of practical skills, sciences to understanding the 
scientific backgrounds of disease etiology and therapy; prevention to preparedness to incorporate health promotion and disease prevention in patient care; holistic care to an appreciation of the impact of multiple (e.g., socio-economic) variables on patients' health and disease; and self-directed learning to reflection on selfperformance with identification of educational needs including expansion of knowledge and skills.

The questionnaire was translated from English into Indonesian language; to secure correctness of the translation, another interpreter performed a reverse translation from Indonesian to English and his translation was compared to the original text.

In classroom sessions attended by the first author, PT students filled in the PHPQ just before the start of their PHC attachments; PT and NPT students filled in the PHPQ shortly after conclusion of the PHC attachments. Reponses on the PHPO were given on a Likert scale ranging from 1 (very inadequately prepared) to 6 (very adequately prepared).

\section{Assessing students' clinical skills performance}

After conclusion of the skills training program for both PT and NPT students, all attended a nine-station "Objective Structured Clinical Examination" (OSCE) (Harden et al. 1975). At each station, a skills instructor assessed a different clinical skill using a standardized checklist. OSCE assessors were "blinded" with respect to information to which experimental group a student belonged (Jefferies et al. 2007).

\section{Assessing students' progress during practice in PHC}

Clinical supervisors in PHC were asked to assess PT students five times during their attachment to PHC centers, using a checklist derived from PHPO by FM-GMU skills laboratory staff(Alreck and Settle 1995). PT students were not informed about these additional assessments to avoid "assessment-induced behavior." The checklist contained eight items matching the eight PHPQ domains and used a six-point rating scale ranging from very poor performance (1) to very good performance (6).

\section{Statistical analysis}

Differences in mean scores of PT and NPT students on the PHPQ questionnaire after execution of the skills training program, and on the OSCE were statistically analyzed using Mann-Whitney's test. The consecutive scores given by supervisors during PT students' attachments to PHC centers were analyzed using Wilcoxon's signed rank test. To avoid false conclusions on significance from a multitude of interdependent data, a Bonferroni correction was applied to determine appropriate p-values to accept statistical significance (Bryman and Cramer 2001). 


\section{RESULTS}

Fifty-seven PT students completed their skills training program (96\%). Two students resigned from the attachment program: one student because of family matters and another one became ill. All NPT students completed their skills training program. All students participated in the OSCE. All GPs in PHC centers supervised PT students throughout the program and five times scored their performance. One student was not scored by his supervisor because he rarely showed up in the PHC center; results are based on supervisors' scores for the remaining 56 PT students.

PT students gave higher scores on PHPQ than their NPT peers. Scores of the two groups were significantly different in the domains: confidence (difference between mean score of PT and mean of NPT: $p<0.000)$, management $(p=0.003)$, collaboration ( $p=0.001)$, self-directed learning $(p=0.000)$, and holistic care $(p=0.003)$. In the domains prevention $(p=0.23)$, science $(p=0.27)$ and interpersonal skills $(p=0.133)$ differences were not significant. OSCE scores of PT and NPT students were not significantly different on all nine stations included.

Comparison of scores of the PT group on PHPQ before and after their training program showed a significantly improved sense of preparedness in the students in three domains: confidence, collaboration, and self-directed learning. The largest effect was in the domain of confidence (difference between mean scores: 0.64 ), followed by collaboration (0.42) and self-directed learning (0.31) (Table 1).

PHC supervisors observed gradual improvement in PT students' performance in all eight domains scored (Figure 1). Differences between first and last scores were significantly different on all domains $(p<0.00)$. According to the scoring by the supervisors, at the end of their attachments to PHC centers, PT students had made most progress in the domain interpersonal skills, consecutively followed by collaboration, science, and self-directed learning.

\section{DISCUSSION}

This study demonstrates the increased effectiveness of a clinical skills training program to prepare pre-clinical students for clerkship practice if practical training in the skills laboratory is partly substituted by training in $\mathrm{PHC}$ centers. Both PT students themselves and their supervisors in PHC centers felt that students' level of preparedness for the clerkships increased significantly in several domains by PHC attachments. On the other hand, PHC attachments had no influence on students' performance on a nine-station OSCE.

This study confirms the results from several studies performed earlier in the setting of industrialized countries. Exposure of pre-clinical students to patients increased their confidence to meet patients, as also concluded by Dornan et al. (2006) in a BEME review. Attending and managing the patients in collaboration with other health workers increased students' sense of preparation for entering the clerkship, as also demonstrated by Hampshire (1998) and mitigated problems 
with the transfer of clinical skills from the skills laboratory to the hospital setting (Seabrook 2004; Morton et al. 2006).

Five consecutive assessments by clinical PHC supervisors indicated gradual improvement of performance of PT students on all eight PHPQ domains: interpersonal skills, self-directed learning, confidence, collaboration, management, prevention, holistic care, and science. However, PT students themselves had the same sense of preparedness as NPT students in the domains of interpersonal skills, science, and prevention. In the domain of interpersonal communication, this may in part be explained by the fact that these skills are less stressful for students than performing physical clinical skills (Sarikaya et al. 2006; Stewart et al. 2007). Furthermore, pre-clinical students may be trained adequately in communication in the skills laboratory with peers and simulated patients (Van Dalen et al. 2001). Lack of an improved sense of preparation with the PT students in the domains of science and prevention may be related to the characteristics of PHC centers in developing countries. Some of these centers have limited facilities and human resources, so these centers may fall short in executing preventive activities. Furthermore, these centers usually have neither library nor learning resources, which may hamper students' expansion of medical knowledge (Shields and Hartati 2006). However, facing clinical problems in reality apparently motivated students to reflect on their own performance, as shown by the higher score of PT students in the domain of selfdirected learning. It may be assumed that those students expanded their knowledge and skills using "contextual" learning resources like GPs and other health workers in the PHC centers.

In the PHC centers, it was not possible to execute all clinical procedures to be addressed in the skills training program due to limitations in budget, human resources, and availability of suitable patient cases (Shields and Hartati 2006). Nevertheless, PT students' performance on an OSCE was similar to that of NPT students. The other way around, one might have expected PT students to perform better than NPT students at least on some OSCE stations. Failure to find difference may be explained by the fact that some OSCE stations addressed clinical procedures like resuscitation and intubation which were most likely not exercised with patients in $\mathrm{PHC}$ centers.

A limitation of this study is that students' perception of preparedness for the clerkships and their clinical skills performance were only explored quantitatively using PHPQ, supervisors' scorings, and an OSCE. In a follow-up study, we will qualitatively investigate possible differences in performance between PT and NPT students early in their clerkships.

Offering PHC attachments to all pre-clinical students will be quite a challenge. Because of their limited clinical experience pre-clinical students need intense supervision (Haffling et al. 2001; Smith 2006). Students, patients and their supervisors should experience a safe setting during the teaching and learning process. The cost of this program should also be taken in consideration, because all stakeholders involved should receive appropriate reward and benefits from the 
attachment program (Dornan et al. 2006). Prolonged availability of budget must warrant that the attachment program is not soon discontinued. In that regard, preparation, planning, and organization of this program must be performed effectively and efficiently, especially in the context of a developing country where budgetary limitations may affect education stronger than in industrialized countries (Stark and Fortune 2003).

\section{CONCLUSION}

Inclusion of PHC attachments in the clinical skills training program for pre-clinical students improved their perception of preparedness for their clerkships. Improvements pertained particularly to domains which cannot be covered sufficiently in the skills laboratory, including improving confidence in attending patients, families, and communities; collaborating with other health workers; and self-directed learning in uncertain situations. The attachment program did not negatively, but neither positively impact on students' performance in an OSCE.

\section{ACKNOWLEDGEMENTS}

We acknowledge Mrs Dany Lukita Sari for assistance with data collection from medical students and PHC supervisors as well as our dedicated student assistants Bina Muntafia Dewintari, Rachmad Ansyori, Muhammad Rizky Yanuar Fauzi, Aloysius Angga Wibowo, Octavianus Kevin and Sesarius Bimo Wicaksono. We express our gratitude to the skills laboratory and the community-based education unit $\left(\mathrm{K}_{3} \mathrm{M}\right)$ in FM-GMU for cooperating in this study. We are indebted to the Dutch NPT Project for financial support.

\section{REFERENCES}

Alreck PL, Settle RB. 1995. The survey research handbook. Richard D. editor. 2nd ed. NewYork: Irwin Inc.

Bryman A, Cramer D. 2001. Quantitative data analysis with SPSS release 10 for windows. East Sussex, FA: Routledge.

Dornan T, Littlewood S, Margolis SA, Scherpbier A, Spencer J, Ypinazar V. 2006. How can experience in clinical and community settings contribute to early medical education? A BEME systematic review. MedTeach 28:3-18.

Haffling AC, Hakansson A, Barbro H. 2001. Early patient contact in primary care: A new challenge. Med Educ 35:901-908.

Hampshire AJ. 1998. Providing early clinical experience in primary care. Med Educ 32:495-501.

Harden RM, Stevenson M, Downie WW, Wilson GM. 1975. Assessment of clinical competence using objective structured examination. BrMed J 1:447-451.

Hill J, Rolfe IE, Pearson EA, Heathcote A. 1998. Do junior doctors feel they are prepared for hospital practice? A study of graduates from traditional and nontraditional medical school. Med Educ 32:19-24.

Jefferies A, Simmons B, Regehr G. 2007. The effect of candidate familiarity on OSCE scores. Med Educ 41:888-891.

Lynagh M, Burton R, Fisher RS. 2007. A systematic review of medical skills laboratory training: Where to from here? Med Educ 41:879-887.

Morton J, Anderson L, Frame F, Moyes J, Cameron H. 2006. Back to future: Teaching medical students clinical procedures. MedTeach 28:723-728. 
Morton J, Anderson L, Frame F, Moyes J, Cameron H. 2006. Back to future: Teaching medical students clinical procedures. MedTeach 28:723-728.

Nielsen DG, Moercke AM, Hansen GW, Eika B. 2003. Skills training in laboratory and clerkship: Connections, similarities, and differences. Med Educ online 8:12.

O'Sullivan M, Martin J, Murray E. 2000. Students' perceptions of the relative advantages and disadvantages of community-based and hospital-based teaching: A qualitative study. Med Educ 34:648-655.

Prince KJAH, Boshuizen HPA, van der Vleuten C, Scherpbier AJJA. 2005. Students opinions about their preparation for clinical practice. Med Educ 39:704-712.

Sarikaya O, Civaner M, Kalaca S. 2006. The anxieties of medical students related to clinical training. J Clin Pract 60:1414-1418.

Seabrook MA. 2004. Clinical students' initial reports of the educational climate in a single medical school. Med Educ 38:659-669.

Shields LE, Hartati LE. 2006. Primary care in Indonesia. J Child Heath Care 10(1):4-8.

Smith B. 2006. From simulation to reality-breaking down the barriers. Clin Teach 3:112-117.

Stark P, Fortune F. 2003. Teaching clinical skills in developing countries: Are clinical skills centres the answer? Educ Health 16:298-306.

Stewart RA, Hauge LS, Stewart RD, Rosen RL, Katsikas AC, Prinz RA. 2007. A CRASH course in procedural skills improves medical students' self-assessment of proficiency, confidence, and anxiety. Am JSurg 193:771-773.

Van Dalen J, Bartholomeus P, Kerkhofs E, Lulofs R, Van Thiel J, Rethans JJ, Scherpbier AJJA, Van Der Vleuten CPM. 2001. Teaching and assessing communication skills in Maastricht: The first twenty years. MedTeach 23:245-251.

Worley P, Prideaux D, Strasser R, Magarey A, March R. 2006. Empirical evidence for symbiotic medical education: A comparative analysis of community and tertiary-based programs. Med Educ 4:109-116. 


\section{APPEN DIXES}

Table 1. Comparison of scores by 57 PT and 134 NPT students on PHPO scores OSCE at the end of their clinical skills training program

\begin{tabular}{|c|c|c|c|c|c|}
\hline \multirow[t]{2}{*}{ Item scores } & \multicolumn{2}{|c|}{ PT students } & \multicolumn{2}{|c|}{ NPT students } & \multirow[b]{2}{*}{$p^{*}$ (Man - Whitney test) } \\
\hline & Mean & SD & Mean & SD & \\
\hline \multicolumn{6}{|l|}{ OSCE stations } \\
\hline $\begin{array}{l}\text { Integrated patien management I } \\
\text { Integrated patient management II }\end{array}$ & $\begin{array}{l}77.24 \\
72.63\end{array}$ & $\begin{array}{r}11.75 \\
7.91\end{array}$ & $\begin{array}{l}76.89 \\
73.36\end{array}$ & $\begin{array}{l}12.68 \\
10.40\end{array}$ & $\begin{array}{l}0.94 \\
0.22\end{array}$ \\
\hline Integrated patien management III & 76.44 & 9.96 & 76.35 & 11.13 & 0.97 \\
\hline Obstetrics and Gynecology & 92.93 & 6.78 & 90.94 & 8.59 & 0.16 \\
\hline \multirow{2}{*}{$\begin{array}{l}\text { Cardio-pulmonary resuscitation } \\
\text { Endotracheal intubation }\end{array}$} & 85.87 & 13.09 & 86.73 & 12.07 & 0.73 \\
\hline & 87.54 & 11.47 & 88.18 & 11.54 & 0.40 \\
\hline Emergency skills & 85.24 & 14.88 & 86.23 & 13.00 & 0.74 \\
\hline Minor surgey & 77.10 & 13.46 & 75.17 & 14.65 & 0.47 \\
\hline Clinical reasoning skills & 67.75 & 16.46 & 66.80 & 16.51 & 0.76 \\
\hline \multicolumn{6}{|l|}{$P H P Q$ sub-scale } \\
\hline Confidence & 4.33 & 0.64 & 3.72 & 0.75 & $0.000^{*}$ \\
\hline Management & 4.25 & 0.82 & 3.83 & 0.70 & $0.003^{\star}$ \\
\hline Colaboration & 4.29 & 0.59 & 3.88 & 0.80 & $0.001^{*}$ \\
\hline Prevention & 4.57 & 1.24 & 4.17 & 0.68 & 0.023 \\
\hline Self-directed learning & 4.33 & 0.57 & 3.93 & 0.71 & $0.000^{*}$ \\
\hline Holistic care & 4.33 & 0.62 & 3.97 & 0.73 & $0.003^{*}$ \\
\hline Science & 4.09 & 0.68 & 3.83 & 0.70 & 0.027 \\
\hline Interpersonal skills & 3.75 & 0.80 & 3.54 & 0.82 & 0.133 \\
\hline
\end{tabular}

Note: *Statisticaly significant after Bonferroni correction, statistical significance was accepted at $p<0.0055$ for the OSCE scores, and $p<0.006$ for PHPQ scores

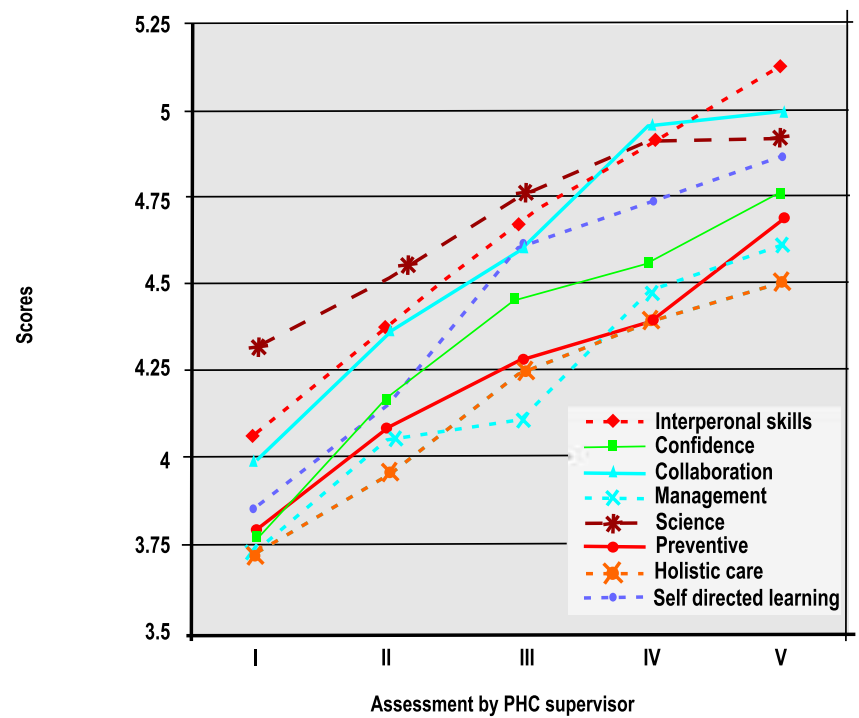

Figure 1. PT. students progress as scored by PHC supervisors.

Note. I-V: Students were weekly assessed on eight domains by their PHC supervisors using a 6-point likert scale ranging from 1 (very poor performance) to 6 (very good performance) 


\section{Chapter6.}

Evaluating the effect of ECE in the first clerkships

\section{Submitted as:}

Widyandana D, Majoor GD, Scherpbier AJJA. Students' experiences in early clerkships after preparatory attachments to primary health care centers: a study from Indonesia

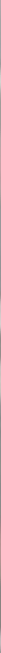




\begin{abstract}
Background: Students may encounter difficulties when they have to apply clinical skills trained in their pre-clinical studies in clerkships. Early clinical exposure in the pre-clinical phase has been recommended to reduce these transition problems. The aim of this study is to explore differences in students' experiences during the first clerkships between students exclusively trained in a skills laboratory and peers for whom part of their skills training was substituted by early clinical experiences (ECE).

Methods: Thirty pre-clinical students trained clinical skills exclusively in a skills laboratory; 30 peers received part of their skills training in $\mathrm{PHC}$ centers. Within half a year after commencing their clerkships all 6o students shared their experiences in focus group discussions (FGDs). Verbatim transcripts of FGDs were analyzed using Atlas-Tisoftware.
\end{abstract}

Results: Clerkship students who had participated in ECE in PHC centers felt better prepared to perform their clinical skills during the first clerkships than peers who had only practiced in a skills laboratory. ECE in PHC centers impacted positively in particular on students' confidence, clinical reasoning, and interpersonal communication.

Conclusion: In the Indonesian setting ECE in PHC centers reduce difficulties commonly encountered by medical students in the first clerkships.

Keywords: clinical skills training, early clinical experiences, clerkships 


\section{BACKGROUND}

Medical institutions across the world have installed clinical skills laboratories to train pre-clinical students' clinical skills (Lynagh et al. 2007). In skills laboratories, pre-clinical students practice their clinical skills with peers, manikins and simulated patients. Skills laboratories provide a safe environment for practice and learning processes therein can be well structured (van Dalen et al. 2001).

However, recent studies have indicated that pre-clinical students entering their clerkships may encounter difficulties when they have to apply clinical skills learned, especially in patient contacts (Radcliffe et al. 2003; Prince et al. 2005; Godefrooij et al. 2010). Students feel anxious when they have to perform diagnostic or therapeutic procedures with patients because they fear to harm patients, to make a wrong diagnosis, and to give inappropriate medical treatment (Sarikaya et al. 2006).

To mitigate transition problems as described above, Dornan et al. (2006) recommended inclusion of early clinical experiences (ECE) in the curriculum for preclinical students. ECE are supposed to improve preparation of pre-clinical students for their clinical rotations by immersing them in the reality of the clinical environment, by facilitating application of knowledge to clinical practice, and by improving students' motivation for learning.

In principle ECE can be offered in any clinical setting, including facilities for primary, secondary and tertiary health care. With respect to primary health care (PHC) some studies have shown the relative advantage of PHC centers to provide opportunities for "hands on" practice by pre-clinical students, availability of general practitioners (GPs) to supervise the students, and with respect to the scope of PHC, which next to patient care also includes community health education (Jhonston and Boohan 2000; Kristina et al. 2006).

Considering the possibilities for ECE and the clinical settings, it is important to know that in order to provide health services to communities in Indonesia, each sub-district has at least one PHC center (called Puskesmas). For example in 2000 in Jogjakarta a sub-district encompassed on average 35,278 people (PemkotJogjakarta, 2002). Each center hosts one or some doctors and paramedics, the latter including nurses, midwives, and pharmacists who may be involved in the teaching of pre-clinical students (Shield and Hartati 2006). The characteristics and the number of $\mathrm{PHC}$ centers available in the proximity of any medical school in Indonesia have led us to elect PHC centers to arrange for ECE for pre-clinical students, particularly to prepare these students for their clinical rotations (Widyandana et al. 2011)

This study was undertaken to explore the effect of ECE in PHC on students' performance in their first clinical clerkships. To this aim, we compared experiences of students exclusively trained in a skills laboratory and peers for whom part of their skills training was substituted by ECE in PHC centers. 


\section{MATERIALSAND METHODS}

This study was conducted with 60 pre-clinical students who were randomly sampled from a full class of 197 fourth year students of the Faculty of Medicine at Gadjah Mada University (FM-GMU) in Jogjakarta, Indonesia. These students were in the last semester of their pre-clinical studies since the medical curriculum of FMGMU has a pre-clinical phase of 3.5 years (and a clinical phase of 1.5 years).

All 6 o students sampled attended the regular clinical skills training program conducted in the skills laboratory. In duos or trios, 30 of these students were offered in addition an 11-day clinical skills training program in PHC centers (PHC-trained: PT). In the PHC centers PT students were supervised by GP's who had been trained to become aware of the standard procedures for clinical skills as taught in FM-GMU's skills laboratory.

The other 30 students received for the same time span additional clinical skills training in the skills laboratory, facilitated by senior students trained to act as skills laboratory assistants (not PHC-trained: NPT). After conclusion of their preclinical program students commenced their clinical rotations in the teaching hospital. Six months after commencing their clinical clerkships all 6o students were invited to participate in Focus Group Discussions (FGDs). By that time, each student had completed three or four clerkships (out of the total of 14). Students were assigned to three focus groups of ten NPT or PT students, respectively.

FGDs were facilitated by the first author and a research assistant. Discussions were structured by the following questions: 1) What is your opinion about pre-clinical training in the skills laboratory as preparation for your clerkships?; 2) What difficulties did you encounter in your first clerkships?; 3) What is your opinion about ECE in PHC centers?; and 4) What is your impression of the performance of students in the other group, compared with the performance of your own group?". Each focus group convened twice and each session continued until no more new items emerged.

FGDs were audiotaped and transcribed verbatim by a research assistant. Transcripts were analyzed by three persons: the first author, a senior clinical supervisor from the teaching hospital, and a research assistant. The first author briefed his co-analyzers about the objective of the study and how to perform open coding using Atlas-Ti version 6. Each coder worked independently to analyze the texts and assigned codes in accord with the main categories (i.e., the four questions asked) and tried to distinguish sub-categories therein (Elo and Kyngäs 2008). To finalize the coding process, a meeting was held with the three coders to discuss their results until consensus was reached. A written summary of the outcomes was distributed among all FGD participants for checking its validity and to solicit comments. Two research assistants met with groups of students and sent e-mails to those not attending to solicit their comments on the summary of the outcomes of the FGDs (Anderson and Arsenault 1998; Fraenkel and Wallen 2009). 


\section{RESULTS}

All 60 students attended at least one of the FGD sessions; the number of participants in each FGD sessions varied between six to twelve.

In the coding process 1,433 issues were identified in the 12 FGD transcripts. During the meeting of the coders consensus was reached that ten sub-categories could be identified, based on the issues most frequently emerging in each main category. In reporting on the outcomes of the FGDs the focus will be on issues mentioned eight times more frequently in either NPT or PT groups to condense presentation of the data in Table 1 . Striking issues mentioned with a frequency difference less than eight times will be highlighted in the text.

In the checking process with FGD participants only minor comments were made with respect to weaknesses of training in the skills laboratory and expectations to practice in PHC centers during the pre-clinical studies. Those comments have been integrated in the final outcome of the FGDs.

\section{Pre-clinical training in skills laboratory}

NPT students more often made positive remarks about their preparation for interpersonal communication skills and had more suggestions for improvement of the skills training program than PT students. On the other hand, PT students more frequently recognized differences between standards for skills as taught in skills laboratory and the way those skills were performed in clinical practice. Both NPT and PT students frequently advised to include ECE in the pre-clinical curriculum (NPT: 30 times, PT: 36 times).

"...the [ECE] program is good, because it improves students' clinical performance [in early clerkship] ... all [pre-clinical] students should have it from the beginning... (NPT/1/1)

\section{Difficulties met in first clerkships}

In this main category large differences emerged in the number of difficulties mentioned by NPT students as compared with PT students. NPT students brought up 202 different problems whereas PT students mentioned only 52. Difficulties to perform clinical skills were mentioned 74 times by NPT students versus 14 times by PT students. Difficulties mentioned by NPT students related to communication skills, including difficulties with interpersonal communication, taking an anamnesis, and understanding the local dialect. NPT students had also encountered more difficulties than PT students with physical examination (e.g., in ophthalmology and neurology) and recognizing pathological signs in patients (e.g., wheezing sounds, liver enlargement, and cardiac murmurs). Both NPT and PT students frequently mentioned that different guidelines given by distinct clinical supervisors negatively impacted on their performance in physical examination. With 
students had suffered most from differences between manikins and patients, e.g. with insertion of intravenous lines, minor surgery, tracheal intubation, urethral catheterization, and assisting at a delivery. More often than PT students NPT students mentioned to be afraid to harm the patient.

"...when we insert an intravenous catheter or perform minor surgery on a manikin, they [the manikins] are not screaming, but pediatric patients are always screaming from the beginning (...) Performing wound suturing on a patient feels really different, [real] skin is much more stretchy..." (NPT/3/1)

Beyond difficulties with the application of clinical skills, NPT more frequently than PT students referred to difficulties in adapting to the clerkship environment, cooperation with other health workers, and with clinical reasoning. NPT students also more often than PT students mentioned low confidence, confusion, and anxiety in front of patients. NPT students shared that they first needed to watch a clinical procedure before performing it themselves.

"...Yes, indeed, because we [PT students] had earlier [clinical] experiences, we are confident and courageous if the supervisors give us opportunities to perform clinical procedures on patients, like inserting an intravenous infusion, venapuncture, minor surgery, delivering a baby, etc. ... It is different with our [NPT] colleagues who prefer to observe prior to performing..." (PT/3/1)

Both NPT and PT students frequently stated that insufficient supervision had been a problem in their first clerkships.

\section{Students' opinions on ECE for pre-clinical students}

Based on their personal experiences, PT students commented extensively on their attachment in PHC centers. Based on their observations also students in NPT groups shared opinions on ECE. The main advantages of ECE identified by many PT students was the opportunity to practice clinical skills in a real health care setting. ECE made PT students aware of differences between the skills laboratory and a clinical environment. ECE had positively impacted on PT students' motivation for learning, on their confidence, clinical reasoning, and interpersonal communication. More than NPT students, PT students were given opportunities by their clerkship supervisors to perform clinical skills.

"....in the ENT department [when students sought permission to perform a clinical skill] the supervisor would always ask: "Did you ever perform this skill [on a patient]?" (...) On the first day [of that clerkship] we [NPT students] observed our [PT] peers [performing that skill] and practiced 
with them. Then in the second day the supervisor would also allow us [NPT students] to perform thatskill..."(NPT/1/2)

Both NPT and PT students recognized that the effectiveness of ECE depends on the quality of supervision in the PHC centers. In particular NPT students were worried that the range of clinical procedures which could be practiced in $\mathrm{PHC}$ centers would be too limited.

"...opportunities to observe various clinical procedures are more available in the Sardjito [teaching] Hospital than in Puskesmas [PHC centers]..." (PT/2/1)

\section{Students' comments based on comparing the groups}

NPT students recognized the advanced functioning of their PT peers in the first clerkships.

"...the way my peer [NPT] student Taysa interacted with patients differed strongly from my [NPT student] performance ... she looked ready [for practice] and knew what should she do with the patient... and I was not." (NPT/1/1)

\section{DISCUSSION}

This study shows that students who participated in ECE in PHC centers had less difficulties than NPT students with the transition from the pre-clinical phase of their studies to the clerkships. In the setting of Indonesia PHC centers proved to be suitable to offerECE to medical students.

ECE impacted in particular on students' confidence, clinical reasoning abilities and interpersonal communication skills. With respect to confidence, PT as well as NPT students (based on experience and observation of peers, respectively) frequently felt ECE had or would boost their confidence. As far as the NPT students are concerned this may be explained by their anxiety and lack of confidence when in their first clerkships they were confronted with patients. Apparently PT students had passed this stage in the PHC centers, where possibly close supervision by GP's had supported them in overcoming this barrier.

Expectations with respect to improving clinical reasoning through ECE were far more frequently voiced by NPT students than by PT students. Perhaps expectations were set too high in the NPT students who had not participated in ECE, or the NPT students were highly impressed by the progress PT students had made with respect to clinical reasoning during ECE.

Opinions of students with respect to interpersonal communication yielded the most convincing data in support of ECE. NPT students mentioned frequently to feel they had been adequately prepared for interpersonal communication by training in the skills laboratory, but apparently this perception was challenged in practice 
because PT students expressed this opinion less frequently than their NPT peers. On the other hand, when PT students had practice because PT students expressed this opinion less frequently than their NPT peers. On the other hand, when PT students had entered the clerkships ECE had apparently erased their difficulties with interpersonal communication, whereas understandably those difficulties persisted in NPT students. This explanation is corroborated by the high frequency by which PT students advocated ECE for practicing interpersonal communication skills.

The reduction of difficulties encountered by PT students in their first clerkships as compared to those encountered by their NPT peers resulted in frequent recommendation by students from both groups to include ECE in the pre-clinical curriculum. It is remarkable that NPT students did not mention the advantage of having clinical experiences in the pre-clinical curriculum, although in the first clerkships they had been impressed by the advanced functioning of their PT peers. Perhaps their failure to see this advantage reflects the doubt whether attachments to $\mathrm{PHC}$ centers can adequately prepare them to perform advanced clinical procedures.

The data gathered from the students confirm the shortcomings of clinical skills training in the skills laboratory to prepare students for the clinical phase of their studies as also observed by others (van Dalen et al. 2001; Nielsen et al. 2003; Al-Jishi et al. 2009). Perhaps offering more sessions with simulated patients and patients manifesting certain pathological conditions (e.g. liver enlargement, heart murmurs), if possible situated in a hospital environment might compensate for some of the shortcomings of skills laboratory training as experienced by NPT students (and thus also by regular students) (Kerr et al. 2005). Furthermore, involving clinical supervisors in the hospital in trainings with (simulated) patients may assist in further adjustment of clinical procedures as taught in the skills laboratory and as performed in practice. On the other hand, ECE seems more efficient to improve preparation of pre-clinical students for their clinical rotations than considerable expansion of the skills laboratory training program. This may be particularly important in developing countries where budget restrictions call for the selection of the most cost-efficient solutions (Stark and Fortune 2003; Shield and Hartati 2006).

Insufficient supervision experienced in the clerkships by both NPT and PT students may have elicited their joint comment that also effectiveness of ECE in PHC relies on the quality of supervision. Also for this pilot experiment FM-GMU skills laboratory staff extensively informed supervisors-to-be in PHC centers about the pre-clinical students' level of competency and their derived learning needs, and about standards for execution clinical procedures as taught in the skills laboratory (Yeates et al. 2008). Unfortunately in many developing countries (including Indonesia), PHC centers may be severely understaffed (Shield and Hartati 2006; Barber et al. 2007). Therefore, in the selection of PHC centers for ECE availability of adequate numbers of supervising staff must be carefully considered, because medical students need close supervision particularly in their first encounters with patients (Smith 2006). 
In the Indonesian setting PHC centers proved to be suitable to offer ECE for preclinical students. Although more advanced equipment and procedures may not be available in PHC centers, this setting was apparently 'clinical' enough to satisfactorily prepare pre-clinical students for functioning in the hospital setting. Training in PHC centers also fits in with the policy of the Indonesian government which requires that every medical graduate must serve for at least half a year in PHC. Furthermore, ECE in $\mathrm{PHC}$ centers may motivate some students to opt for a future career in PHC (Dornan et al. 2006).

A limitation of this study is that the assessment of the effectiveness of ECE in $\mathrm{PHC}$ centers was only based on student opinions. By involving students representing two different groups (i.e., PT and NPT) and by comparing their mutual opinions we aimed to improve the validity of these subjective data. Furthermore, we have taken the paucity of significant comments by FGD participants on the summary of the FGD sessions as support for the validity of the analyzing process as applied.

In a future study we intend to involve objective assessment tools to compare the clinical performance of NPT and PT students during their first clerkships. A suitable approach in this respect could be assessment by direct observation using the Mini-Clinical Evaluation Exercise (Mini-CEX) (Norcini and Burch 2007).

\section{CONCLUSION}

In the setting of a developing country, an 11-day ECE program in PHC centers was demonstrated to significantly reduce difficulties as commonly encountered by pre-clinical students in their first clinical clerkships.

\section{ACKNOWLEDGEMENTS}

The authors are indebted to Dr. Bambang Djarwoto and Ms. Bina Muntafia Dewintari for providing assisting with analyzing FGD transcripts. We gratefully acknowledge the contributions of student assistants. Our studies were facilitated by the Department of Medical Education at FM-GMU and financially supported by a Dutch NPT project.

\section{REFERENCES}

Al-Jishi E, Khalek NA, Hamdy HM. 2009. Students' perceptions of the effectiveness of a professional skills program in preparation for clerkship training. Educ Health 22:1-7.

Anderson G, and Arsenault N. 1998. Fundamentals of Educational Research. 2nd edition. London: Falmer Press.

Barber SL, Gertler PJ, Harimurti P. 2007. The contribution of human resources for health to the quality of care in Indonesia. Health Aff 26:367-379.

Dornan T, Littlewood S, Margolis SA, Scherpbier A, Spencer J, and YpinazarV. 2006. How can experience in clinical and community settings contribute to early medical education? A BEME systematic review. MedicalTeacher 28:3-18.

EloS, Kyngäs H. 2008. The qualitative content analysis process. J Adv Nursing 62:107-115.

Fraenkel JR, Wallen NE. 2009. How to Design and Evaluate Research in Education. 8th edition. New York: McGraw-Hill. 
Godefrooij MJ, Diemers AD, Scherpbier AJJA. 2010. Students' perceptions about the transition to the clinical phase of a medical curriculum with preclinical patient contacts; a focus group study. BMC Med Educ 10(28):1-9.

Johnston BT, Boohan M. 2000. Basic clinical skills: Don't leave teaching to the teaching hospitals. Med Educ 34:692-699.

Kerr JR, Dowie A, Dowell J, Dewar G, Dent JA, Ramsay J, Benvie S, Bracher L, Jackson C. 2005. Twelve tips for developing and maintaining a simulated patient bank. MedTeach 27(1):4-9.

Kristina TN, Majoor GD, Van der Vleuten CPM. 2006. A survey validation of generic objectives for community-based education in undergraduate medical training. Educ Health 19(2):189-206.

Lynagh M, Burton R, Fisher RS. 2007. A systematic review of medical skills laboratory training: where to from here? Medical Education 41:879-887.

Nielsen DG, Moercke AM, Hansen GW, and Eika B. 2003. Skills Training in Laboratory and Clerkship: Connections, Similarities, and Differences. Medical Education online 8:12.

Norcini J, Burch V. 2007. Workplace-based assessment as an educational tool: AMEE Guide No. 31. Med Teach 29:855-871.

Pemkot-Jogjakarta. 2002. Kondisi geografis kota Jogjakarta. http://www.jogjakota.go.id/index/extra. detail/22

Prince KJAH, Boshuizen HPA, van derVleuten C, and Scherpbier AJJA. 2005. Students opinions about their preparation for clinical practice. Medical Education 39:704-712.

Radcliffe C, Lester H. 2003. Perceived stress during undergraduate medical training: a qualitative study. Med Educ 37:32-38.

Sarikaya O, Civaner M, and Kalaca S. 2006. The anxieties of medical students related to clinical training. Journal of Clinical Practice 60:1414-1418.

Shields LE, and Hartati LE. 2006. Primary Care in Indonesia. J Child Health Care 10(1):4-8.

Smith B. 2006. From simulation to reality-breaking down the barriers. The Clinical Teacher 3:112-117.

Stark P, and Fortune F. 2003. Teaching clinical skills in developing countries: are clinical skills centres the answer? Education for Health 16:298-306.

Van Dalen J, Bartholomeus P, Kerkhofs E, Lulofs R, Van Thiel J, Rethans JJ, Scherpbier AJJA, Van Der Vleuten CPM. 2001. Teaching and assessing communication skills in Maastricht: the first twenty years. MedTeach 23:245-251.

Widyandana D, Majoor GD, Scherpbier AJJA. 2011b. Effects of partial substitution of pre-clinical skills training by attachments to primary health care centers: An experimental study. Med Teach 33(6):e313-337.

Yeates PJA, Stewart J, Barton JR. 2008. What can we expect of clinical teachers? Establishing consensus on applicable skills, attitudes and practices. Med Educ 42:134-142. 


\section{APPENDIX:}

\section{Table 1. Iss ues referred to eight times more frequently in FGDs with NPT and PT students}

\begin{tabular}{|c|c|c|c|}
\hline \multirow{2}{*}{$\begin{array}{c}\text { Major ca tegcries and sub- } \\
\text { categories }\end{array}$} & \multirow[t]{2}{*}{ Issues } & \multicolumn{2}{|c|}{ Groups } \\
\hline & & NPT & PT \\
\hline \multicolumn{4}{|l|}{$\begin{array}{l}\text { Pre-clinical training in } \\
\text { skills laboratory }\end{array}$} \\
\hline $\begin{array}{l}\text { streng thsof traning in } \\
\text { skils laboratory }\end{array}$ & Prepaing for interpersonal communicaticn & $12 *$ & 4 \\
\hline $\begin{array}{l}\text { Weak peasses of training n } \\
\text { skils laboratory }\end{array}$ & $\begin{array}{l}\text { Dfferences betwen skills laborato } y^{\prime} \text { s } \\
\text { guidelines and procedures on site }\end{array}$ & 15 & 23 \\
\hline $\begin{array}{l}\text { Sugjestionsto imp rove } \\
\text { traning instills lahoratery }\end{array}$ & $\begin{array}{l}\text { Hajing more topics for practice including } \\
\text { rommunication skills, pediatric exammation, } \\
\text { local languege, clerkshij preparation, etc }\end{array}$ & $3^{8}$ & 25 \\
\hline \multicolumn{4}{|l|}{$\begin{array}{l}\text { Difficulties in first } \\
\text { clerkships }\end{array}$} \\
\hline $\begin{array}{l}\text { Drficulteswill } \\
\text { corrmunication }\end{array}$ & $\begin{array}{l}\text { Drficultes relsted te irterpersor bl } \\
\text { communica:ion }\end{array}$ & 12 & 0 \\
\hline \multirow{2}{*}{$\begin{array}{l}\text { Dfficulteswith physica } \\
\text { examination }\end{array}$} & Different guidelines from various supervisars & 21 & 9 \\
\hline & $\begin{array}{l}\text { Drficulty orecognize apa toological condition in } \\
\text { oxtients }\end{array}$ & 14 & 2 \\
\hline \multirow{2}{*}{$\begin{array}{l}\text { Dfficulteswith diagmastic } \\
\text { and therapeutic scills }\end{array}$} & Diferences betwen mank ns and patients & 17 & 2 \\
\hline & Afraid of harming the patiorit & 10 & 1 \\
\hline \multirow[t]{8}{*}{ Ganeral difficultie; } & 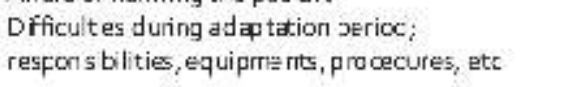 & 28 & 8 \\
\hline & Insuffirient sumenvision & $x_{1}$ & $\because y_{1}$ \\
\hline & $\begin{array}{l}\text { Defficultes in collaborit o with otherhealt a } \\
\text { workers, heslth aut horities, otc }\end{array}$ & 10 & 2 \\
\hline & Low confidence ir front of palierits & is & 3 \\
\hline & Confused in front of patents & 11 & 2 \\
\hline & Nervousin fro rit of patients & 11 & 1 \\
\hline & $\begin{array}{l}\text { NPT studen:s need to o sserve first before } \\
\text { os formina d dinicd ski lin first clerk hios }\end{array}$ & 15 & 2 \\
\hline & Dfficultes wi h clinical -easonina abilitv & 12 & 6 \\
\hline
\end{tabular}




\section{Pre-clinical training in skills laboratory}

Strengthso-trairing in

skills laboraso $\gamma$

Weaknes ses of training in

skills laboraso $y$

Suggestions to imorove

training inskils labcratory

Preparing fo- interpersonal corrmuncation

Diferences betwexn skills laboratory's

Having more top ics for practice including

comınunication skils, pediatric exarrinaticn

local lariguage, ckerkship prepasation, etc.

\section{Difficulties in first}

\section{clerkships}

Dificulteswith

Difficulties related to interpersonal

communica:ion communication

Drficulte swith physical

exarrinetion

Different guädelines from various supewisom

Dificulty to - exognize a patholocicalconditior in Derients

Dificulteswith dagnostic and therapestic skills

Goreral difficul ties

Diferences between manikins and patie

Afraid of harmicis the vati ait:

Dfficulties during adaptation period:

responsibilitie, equiprons, procedures, etc

Ingutioent surervision

Dfficulties in ollaborationwith Jther hesth

workes. health authorities. etc.

Low confide ce in frort of patients

Confused in front of Datients.

Nervous in front of patients

NPT sturlents need to olkenve first hefore

pe for ring a dinical skill in first derkhips

Dfficulties with dinical reasoning ablity

* Cumulative frequereyby witictia similar issue vas mentioned in FGDs 


\section{Chapter 7. GENERALDISCUSSION}

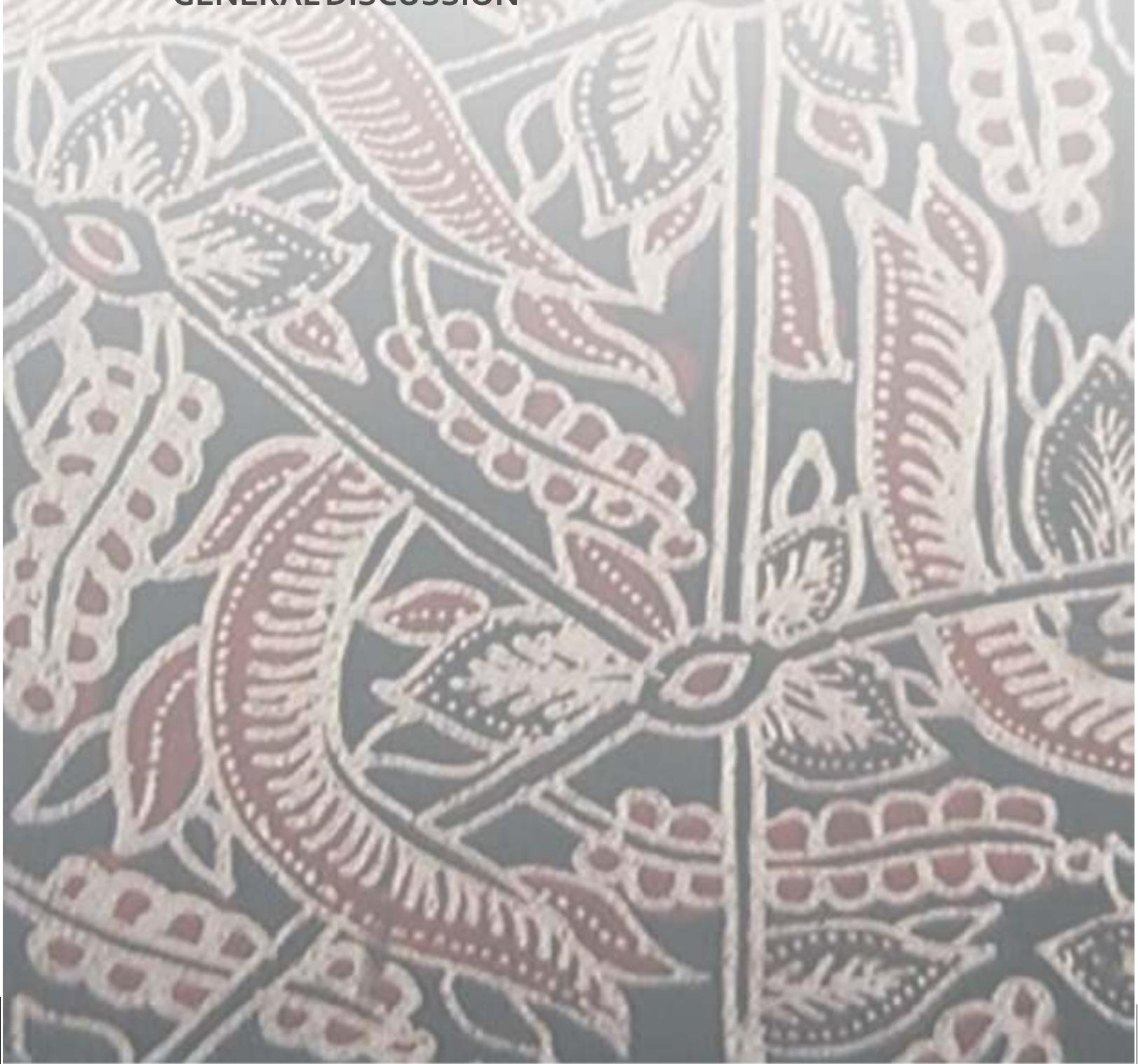




\section{INTRODUCTIONAND RESEARCHQUESTIONS}

Medical education institutions worldwide offer undergraduate curricula in two phases: the first, preclinical or bachelor phase, which prepares students for the second, clinical or master phase. During the three- or four-year preclinical phase, students predominantly participate in learning activities on campus, such as lectures, tutorial group sessions, laboratory practicals, and clinical skills training, the latter often in a dedicated skills laboratory. Preclinical skills training is mostly scheduled longitudinally over the curriculum, and structured and delivered in a "safe" laboratory environment aimed at facilitating skills acquisition (Remmen et al. 2001; van Dalen et al. 2001). All learning activities are aimed at preparing students for the clinical phase.

Despite all the efforts to offer students optimal preparation for the clinical phase, studies have shown that the transition from the preclinical to the clinical phase is often stressful to students and causes substantial problems. Students experience difficulty in adapting to the clinical setting due to the new, very different, educational environment, with different room settings, medical equipment, types of learning activities, extensiveness of supervision, and a much higher workload (Prince et al. 2005). In developing countries these 'transition problems' may be intensified even further due to the very limited budget available to equip health care centers (Stark and Fortune 2003; Shield and Hartati 2006). The above-mentioned differences between the preclinical and the clinical educational setting complicate the transition from campus to hospital for students. They experience low confidence and high anxiety, and feel nervous when they have to perform the clinical skills they have learned in the skills laboratory in the care of real patients in the hospital (Hayes et al. 2004; Smith 2006; Sarikaya et al. 2006; Widyandana et al. 2010).

Dornan (2006) recommended integration of 'early clinical experiences' (ECE) in the preclinical curriculum as a way of improving students' readiness for the clinical phase. For training in a skills laboratory has its limitations, an important one being that in the laboratory students perform skills in encounters with simulated rather than real patients (van Dalen et al. 2001; Bradley and Postlethwaite 2003; Nielsen et al. 2003). ECE can offer students more realistic experiences in the clinical setting and is therefore presumed to help optimize students' preparation for the clinical phase.

This thesis explored the effectiveness of a variant of ECE in preparing students for clinical training, especially with regard to clinical skills. The studies were conducted in the context of a developing country (Indonesia), and addressed the following main research questions:

1. Which problem(s) do medical students encounter during their first clerkships when they have to perform clinical skills learned in the skills laboratory? What remedies do students propose to overcome these problems? 
2. Which of the available clinical settings ( $\mathrm{THC}, \mathrm{SHC}$, or $\mathrm{PHC}$ ) is most appropriate for preclinical skills training? How do patients in that setting respond to the presence of students?

3. What is the effect of a combination of skills training in a skills laboratory with training in a clinical environment on students' level of preparedness on entering clinical training?

\section{DISCUSSIONOFTHE MAIN FINDINGS Transition problems}

The first study confirmed that Indonesian students also encounter problems during the transition from the preclinical to the clinical phase. Students suggested early patient contacts in the preclinical program as a way to enhance their readiness for the clerkships. The problems encountered and students' suggestions on how to deal with them were similar to those reported in earlier studies in the Netherlands (Prince et al. (2005), Godefrooij et al. (2010). The results differed, however, in that the problems of the students in the Dutch studies pertained mainly to professional and social factors and to a lack of communication skills, whereas the problems identified in the studies presented in this thesis were related to the performance of (invasive) diagnostic and therapeutic skills. Another worry of the Indonesian students, which may be specific for the setting of a developing country, was students being anxious that their failure to perform a procedure involving disposables correctly would increase costs for patients - which most likely would not be covered by the patients' health insurance.

\section{PHC centers as training sites}

A study was undertaken to compare three clinical environments (THC, SHC, and PHC) that might be suitable for ECE. Students with some clerkship experience and clinical supervisors both thought that $\mathrm{PHC}$ centers would provide a significantly better learning environment compared with $\mathrm{SHC}$ and $\mathrm{THC}$, because of the availability of supervisors who have time for teaching, the availability of suitable physical facilities and equipment, and the variety of simple patient cases (Widyandana et al. 2011a). Moreover, patients in PHC centers responded positively to encounters with preclinical students, welcomed students' future participation in the work of the center as an opportunity for them to gain practical experience (Widyandana et al. submitted-a). Comparable findings have been reported in other studies (Johnston and Boohan 2000; Haffling and Hakansson 2008), although there have also been studies in which patients expressed concern about maintaining informed consent and confidentiality in the educational program and about preclinical students' level of competence (Coleman and Murray 2002; Benson et al. 2005). No such concerns were expressed by the patients in PHC centers that were involved in the studies presented in this thesis. 
After the identification of PHC centers as the preferred environment for preclinical skills training, a consecutive study demonstrated that students who had experienced a mixed program of clinical skills training in the skills laboratory and in PHC centers (PT group) felt better prepared for clerkships than students trained exclusively in the skills laboratory (NPT group) (Widyandana et al. 2011b). Other studies have also reported that as a result of ECE students felt better prepared for clerkships and more confident to perform clinical skills (Hampshire 1998; Dornan et al. 2006).

\section{ECEforpreparing students for entering the clerkships}

Students from the PT group (who had taken part in the ECE program) recognized the advantages of ECE during their first clerkships (Widyandana et al. submitted-b). As also reported by others, ECE motivates students to study, improves their clinical reasoning ability, and facilitates the transfer of clinical skills from the skills laboratory to the clinical setting (Dornan et al. 2006; Diemers et al. 2007). Since training in a skills laboratory cannot fully mimic practice in clinical settings (Nielsen et al. 2003; Lynagh et al. 2007), ECE may complement laboratory training through familiarizing students with the realities of clinical settings and offering them better preparation for clerkships by enhancing their confidence, clinical skills performance, and clinical reasoning skills (Dornan et al. 2006; Bell et al. 2009; Diemers et al. 2011). This thesis confirms those findings by showing that, compared to laboratory training only, skills training in a laboratory as well as in PHCs made students feel more ready for clerkships.

Clinical skills training is an essential component of preclinical medical education, enabling students to integrate knowledge, skills, and attitudes (van Dalen et al. 2001). Therefore, this thesis focused on clinical skills training, both in the preclinical phase and in the early stages of the clinical phase of undergraduate medical education. Clinical skills cannot be learned from books, they must be learned through repeated practice, starting from simple skills in the first year and progressing to increasingly complex skills in later years. In order to become competent, students also need clinical experiences in both the skills laboratory and clinical settings (van Dalen et al. 2001; Bradley and Postlethwaite 2003). ECE may compensate for the inherent weaknesses of learning in a skills laboratory (Nielsen et al. 2003; Smith 2006), which may be particularly prominent in developing countries where budget constraints usually impact on the availability of facilities and equipment, such as hi-tech simulators (Stark and Fortune 2003; Kneebone et al. 2004). Training preclinical students in a clinical environment may assist in compensating for weaknesses of skills laboratory training (Stark and Fortune 2003; Kristina et al. 2006b). In fact, educational institutions in both developing and industrialized countries have introduced ECE in the preclinical phase (Kristina et al. 2006a; Yardley et al. 2010; Diemers et al. 2011; Widyandana et al. 2011b). 


\section{Using PHC centers for ECE}

These studies involved PHC centers which, as partners of the medical school's skills laboratory, deliver a preclinical skills training program. ECE has many advantages, not only in industrialized countries, but also in developing countries, including Indonesia. For industrialized countries, the rationale for ECE is mainly rooted in educational considerations, such as providing contextual experiences for students and raising students' motivation to learn (Worley et al. 2006; Diemers et al. 2011). In developing countries in particular, the need to use budgets as efficiently as possible calls for an exchange of benefits between education institutions and collaborating health services. This can be achieved for example when GPs in PHC centers supervise students in exchange for receiving up-to-date health information from campus and students' assistance in service delivery (Kristina et al. 2006b; Widyandana et al. 2011b). In Indonesia, PHC centers are densely distributed over the country, with many located in the vicinity of medical schools (Shield and Hartati 2006; Barber et al. 2007). Since PHC centers serve the communities around them, they can provide adequate opportunities for 'hands on' practice for preclinical students (Hampshire et al. 1998; Kristina et al. 2006a; Worley et al. 2006).

In primary care centers students can practice their clinical skills with 'new' patients usually presenting with quite simple complaints, which are suitable to meet students' learning objectives (O'Sullivan et al. 2000; Worley et al. 2006). Patients in $\mathrm{PHC}$ centers have been found to welcome preclinical students to practice their clinical skills with them (Coleman and Murray 2002; Benson et al. 2005; Haffling and Hakansson 2008). Moreover, attachments to PHC centers may motivate medical students to opt for a future career in primary care (Gonzales et al. 2001; Dornan et al. 2006).

\section{Differences between industrialized and developing countries related to $E C E$}

These studies were conducted in the setting of a developing country, which is most likely to differ considerably from settings in an industrialized country. In industrialized countries, medical schools can usually afford advanced facilities for simulations in the skills laboratory, and health care institutions are well equipped. Those characteristics may be different in developing countries where facilities for education and health services are often restricted due to a lack of financial resources (Stark and Fortune 2004; Shield and Hartati 2006). Human resources for health services are also limited, especially in a large developing country like Indonesia (Barber et al. 2007; Heywood et al. 2011). Under those circumstances even the involvement of preclinical students can contribute to service provision in a PHC. Students can for example make a contribution to home visits, health promotion, and health surveys (Kristina et al. 2006a). This may be different in industrialized countries, which usually have well-equipped (primary) health care systems. In such settings, there may be limited possibilities for preclinical students to practice, 
also because of considerations of patient safety and ethical issues (Doyal 2001; Martinez and Lo 2008).

\section{Challenges of ECE}

ECE has a potential weakness, which needs to be addressed. Preclinical students are still only halfway their learning program, and as a result their participation in patient care may pose a threat to patient safety and disturb the provision of health services (Howe 2001; Gonzales et al. 2001). That is why it is of the utmost importance to undertake appropriate preparation for such a program with careful attention for educational training of student supervisors and standardization of equipment to maximize compatibility with skills laboratory standards (Howe 2001; Dornan et al. 2006). Moreover, the skills laboratory should ensure that students have reached a certain standard of competency before they are allowed to attend to patients in PHC centers. And even then, the presence of a clinical supervisor during encounters of preclinical students and patients is mandatory to ensure patient safety and satisfaction. Others have shown for example that students performing a clinical procedure (e.g. inserting intravenous catheter) for the first time must be closely supervised and supported (Kneebone et al. 2002; Smith 2006).

However, not every situation in the clinical setting can be fully controlled, as was emphasized by Spencer (2003), who described challenges in this respect like time pressure, availability of suitable patient cases, shortage of supervisors, and the presence of too many students. Educational institutions, the management of the skills laboratory in particular, must make every effort to minimize these potential problems. Others have recommended careful selection of PHC centers, adequate preparation of program and staff, and maintaining adequate communication between school and training centers (Howe 2001; Gonzales et al. 2001; Diemers et al. 2007).

In addition to measures to ensure both good teaching and patient safety, continuity of the program can also be promoted through the benefits $\mathrm{PHC}$ centers gain from participation in an ECE program (Howe 2001; Dornan et al. 2006; Kristina et al. 2006b). For example, staff in health service environments are usually too busy with their daily activities to find time to keep up with the latest medical knowledge and developments (Howe 2001; Shield and Hartati 2006; Heywood et al. 2011). When a health center participates in ECE, students can share the up-to-date information they have acquired on campus with staff in the center. On campus students also learn how to deliver a presentation and how to educate patients effectively. Therefore, during their practice in PHC centers, students may be expected to strengthen health services, including health promotion in the communities. In this way, ECE programs can initiate or expand collaboration between educational institutions and (primary) health care services (Kristina et al. 2006b; Dornan et al. 2006). 


\section{LIMITATIONS}

A limitation of the studies in this thesis is that they were conducted in a single medical school in Indonesia. This may raise questions as to the generalizability of the results to other schools and other geographical settings. In the studies this weakness was compensated for by collecting data from three different sources, students, clinical supervisors and patients, in order to increase the reliability of the results. The results are also confirmed by those of other studies conducted in medical schools in different countries (Hayes et al. 2004; Prince et al. 2005; Smith 2006, Sarikaya et al. 2006; Kristina et al. 2006a; Widyandana et al. 2011b). This adds to the likelihood that the findings presented in this thesis can be generalized to other geographical settings. Nevertheless, similar studies should be conducted in other (developing) countries to explore the wider applicability of the outcomes of the studies presented in this thesis.

In chapter 5 of this thesis it was demonstrated that ECE in primary care centers improved students' preparedness for clinical training. This finding was based on students' subjective perceptions of their first clerkship experiences. However, subjectivity was reduced by comparing the opinions of two different groups of students. Students' experiences in applying their clinical skills during their first clinical rotations were explored in focus group discussions among students who had (PT group) and students who had not (NPT group) participated in ECE. The assumption is that more reliable data were obtained by comparing the experiences of PT and NPT students.

Nevertheless, future studies should use additional instruments to measure the effect of ECE on students' ability to apply their clinical skills also in the early stages of clinical training. Useful instruments for this purpose might be structured direct observation (e.g. using 'Mini-Clinical Evaluation Exercise' (mini-CEX) and 'Direct Observation of Procedural Skills' (DOPS)) by multiple assessors including clinical supervisors, other health care personnel, and peers (Wass et al. 2001; Norcini and Burch 2007). As stated by Howe (2001), the development of adequate assessment in ECE remains a challenge for the future.

\section{IMPLICATIONS FOR PRACTICE}

Practical experience with ECE has already been gained in Indonesia, where ECE has been integrated with FM-UGM's longitudinal preclinical skills training program since 2008. ECE is organized by skills laboratory staff in the 'Integrated Patient Management' program. In each year of the preclinical curriculum students commence with skills training in the skills laboratory. At the end of each year all students have to practice the clinical skills they have learned in an authentic setting, such as communities, PHC centers, and hospital emergency rooms (Claramita and Widyandana 2008). By the end of the third year, students practice their clinical skills in PHC centers, where they also learn about the organization of the health care system and gain experience with provision of health promotion and $\mathrm{PHC}$ services 
(Widyandana et al. 2011). The experience of FM-GMU demonstrates that ECE, if organized in PHCs, is feasible in the setting of a developing country, in this particular case Indonesia.

\section{REFERENCES}

Barber SL, Gertler PJ, Harimurti P. 2007. The contribution of human resources for health to the quality of care in Indonesia. Health Aff 26:367-379.

Bell K, Boshuizen HPA, Scherpbier A, Dornan T. 2009. When only the real thing will do: junior medical students' learning from real patients. Med Educ 43: 1036-1043.

Benson J, Quince T, Hibble A, FanshaweT, Emery J. 2005. Impact on patients of expanded, general practice based, student teaching: observational and qualitative study. Br Med J 331(89):1-6.

BradleyP, Postlethwaite K. 2003. Setting up a clinical skills learning facility. Med Educ 37:6-13.

Coleman A, Murray E. 2002. Patients' views and feelings on community-based teaching of undergraduate medical students: a qualitative study. Fam Prac 19:183-188.

Diemers AD, Dolmans JM, Santen MV, Luijk SJV, Noordman AMBJ, Scherpbier AJJA. 2007. Students' perceptions of early patient encounters in a PBL curriculum: a first evaluation of the Maastricht experience. MedTeach 29:135-142.

Diemers AD, van den Wiel MWJ, Scherpbier AJJA, Heineman E, Dolmans DHJM. 2011. Pre-clinical patient contacts and the application of biomedical and clinical knowledge. Med Educ 45:280-288.

Dornan T, Littlewood S, Margolis SA, Scherpbier AJJA, Spencer J, YpinazarV. 2006. How can experience in clinical and community settings contribute to early medical education? A BEME systematic review. MedTeach 28:3-18.

Doyal L. 2001. Closing the gap between professional teaching and practice. A policy can help protect students from being asked to behave unethically. Br Med J 322:685-686.

Godefrooij MJ, Diemers AD, Scherpbier AJJA. 2010. Students' perceptions about the transition to the clinical phase of a medical curriculum with preclinical patient contacts; a focus group study. BMC Med Educ 10(28):1-9.

Gonzales AO, Blavo C, Barley G, Steinkohl DC, Loeser H. 2001. What did we learn about early clinical experience? Acad Med 76(4suppl):S49-S54.

Haffling AC, Hakansson A, Barbro H. 2001. Early patient contact in primary care: A new challenge. Med Educ 35:901-908.

HampshireAJ. 1998. Providing early clinical experience in primary care. Med Educ 32:495-501.

Hayes K, Feather A, Hall A, Sedgwick P, Wannan G, Weisser-Smith A, Green T, McCrorie P. 2004. Anxiety in medical students: is preparation for full time clinical attachments more dependent upon differences in maturity or on educational programmes for undergraduate and graduate entry students? Med Educ38:1154-1163.

Heywood P, Harahap NP, Aryani S. 2011. Recent changes in human resources for health and health facilities at the district level in Indonesia: evidence from 3 districts in Java. Hum Res Health 9:5.

Howe A, Anderson J. 2003. Involving patients in medical education. Br Med J 327:326-328.

Johnston BT, Boohan M. 2000. Basic clinical skills: Don't leave teaching to the teaching hospitals. Med Educ 34:692-699.

Kneebone R, Kidd J, Nestel D, Asvall S, Paraskeva P, Darzi A. 2002. An innovative model for teaching and learning clinical procedures. Med Educ 36:628-634.

Kneebone RL, Scott W, Darzi A, Horrocks M. 2004. Simulation and clinical practice: strengthening the relationship. Med Educ 38:1095-1102.

Kristina TN, Majoor GD, Van der Vleuten CPM. 2006a. Does community-based education come close to what it should be? A case study from the developing world: students' opinions. Educ Health 19(2):179-188.

Kristina TN, Majoor GD, Van der Vleuten CPM. 2006b. A survey validation of generic objectives for community-based education in undergraduate medical training. Educ Health 19(2):189-206. 
Lynagh M, Burton R, Fisher RS. 2007. A systematic review of medical skills laboratory training: Where to from here? Med Educ 41:879-887.

MartinezW, Lo B. 2008. Medical students' experiences with medical errors: an analysis of medical student essays. Med Educ 42:733-741.

Nielsen DG, Moercke AM, Hansen GW, Eika B. 2003. Skills training in laboratory and clerkship: connections, similarities, and differences. Med Educ Online 8(12):1-15.

Norcini J, Burch V. 2007. Workplace-based assessment as an educational tool: AMEE Guide No. 31. Med Teach 29:855-871.

O'Sullivan M, Martin J, Murray E. 2000. Students' perceptions of the relative advantages and disadvantages of community-based and hospital-based teaching: A qualitative study. Med Educ 34:648-655.

Prince KJAH, Boshuizen HPA, van derVleuten CPM, ScherpbierAJJA. 2005. Students' opinions about their preparation for clinical practice. Med Educ 39:704-712.

Remmen R, Scherpbier A, van derVleuten C, Denekens J, Derese A, Hermann I, Hoogenboom R, Kramer A, van Rossum H, van Royen P, Bossaert L. 2001. Effectiveness of basic clinical skills training programmes: a cross-sectional comparison of four medical schools. Med Educ 35:121-128.

Sarikaya O, Civaner M, Kalaca S. 2006. The anxieties of medical students related to clinical training. J Clin Pract 60:1414-1418.

Shields LE, Hartati LE. 2006. Primary care in Indonesia. J Child Health Care 10(1):4-8.

Smith B. 2006. From simulation to reality-breaking down the barriers. Clin Teach 3: 112-117.

Spencer J. 2003. ABC of learning and teaching in medicine. Learning and teaching in the clinical environment. BrMed J 326:591-594.

Stark P, Fortune F. 2003. Teaching clinical skills in developing countries: Are clinical skills centres the answer? Educ Health 16:298-306.

Van Dalen J, Bartholomeus P, Kerkhofs E, Lulofs R, Van Thiel J, Rethans JJ, Scherpbier AJJA, van der Vleuten CPM. 2001. Teaching and assessing communication skills in Maastricht: the first twenty years. MedTeach 23: 245-251.

Wass V, van derVleuten C, Shatzer J, Jones R. 2001. Assessment of clinical competence. Med Educ Quartet 357:945-949.

Widyandana D, Majoor G, Scherpbier A. 2010. Transfer of medical students' clinical skills learned in a clinical laboratory to the care of real patients in the clinical setting: the challenges and suggestions of students in a developing country. Educ Health 23 (3):1-6.

Widyandana D, Majoor GD, Scherpbier AJJA. 2011a. Comparison of three clinical environments for preclinical clinical skills training. MedTeach Online: 1-5. (DOI:10.3109/0142159X.2011.558141).

Widyandana D, Majoor GD, Scherpbier AJJA. 2011. Effects of partial substitution of pre-clinical skills training by attachments to primary health care centers: An experimental study. Med Teach 33(6): e313-337.

Widyandana D, Majoor GD, ScherpbierAJJA. Patients' appreciation of pre-clinical students' performance in primary health care centers in Indonesia. Submitted-a.

Widyandana D, Majoor GD, Scherpbier AJJA. Students' experiences in early clerkships after preparatory attachments to primary health care centers: a qualitative study. Submitted-b.

Worley P, Prideaux D, Strasser R, Magarey A, March R. 2006. Empirical evidence for symbiotic medical education: A comparative analysis of community and tertiary-based programmes. Med Educ 40:109-116.

YardleyS, Littlewood S, Margolis S, ScherpbierA, Spencer J, YpinazarV, Dornan T. 2010. What has changed in the evidence for early experience? Update of a BEME systematic review. Med Teach 32: 740-746. 


\section{Chapter 8. SUMMARY}

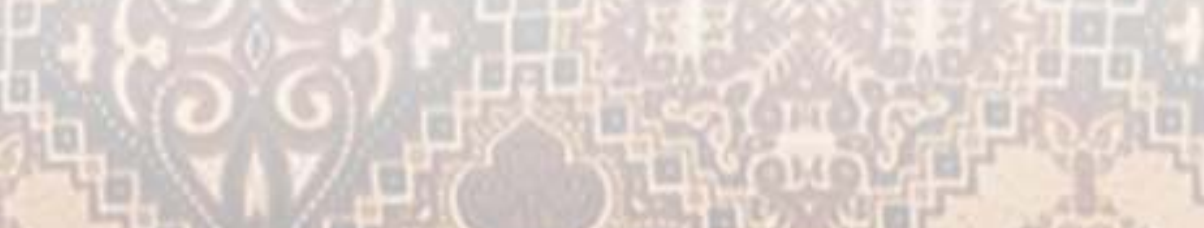
ob. Q⿻

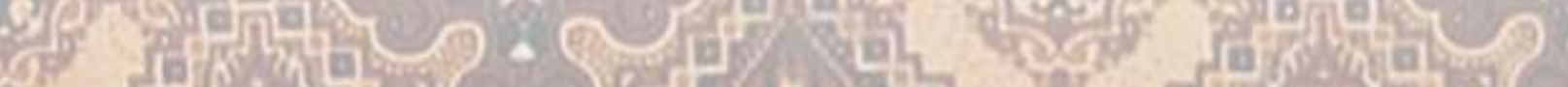
refof.

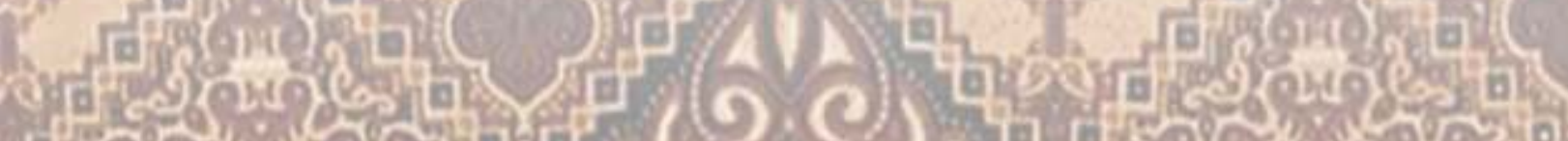

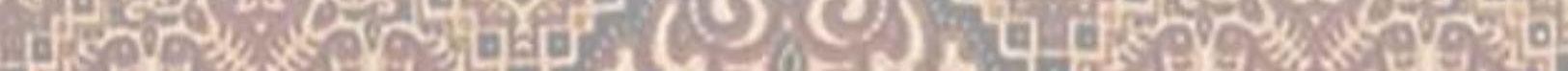
affy

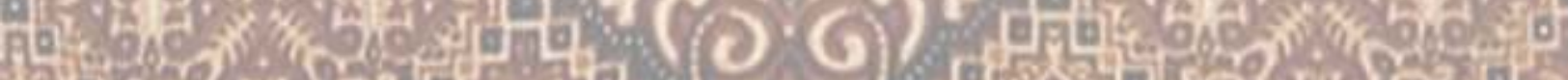

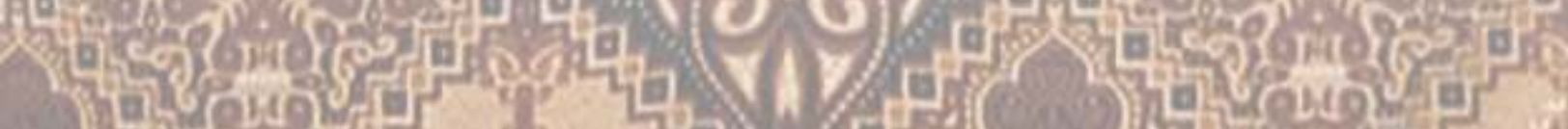

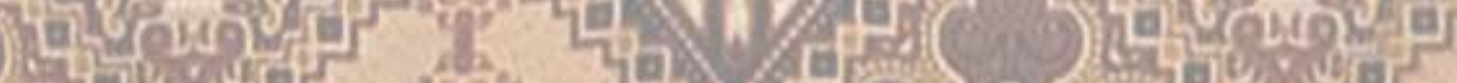

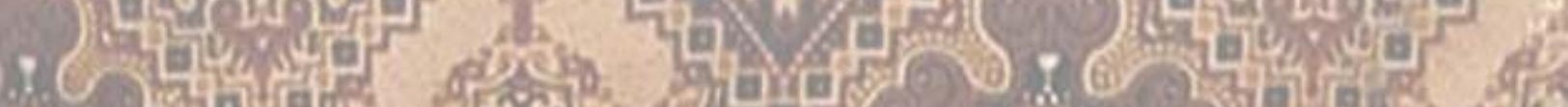
\&.6. X.

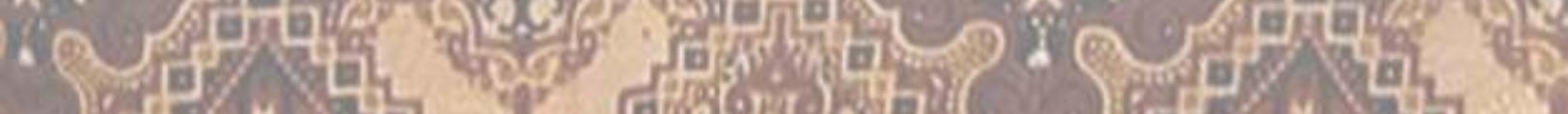

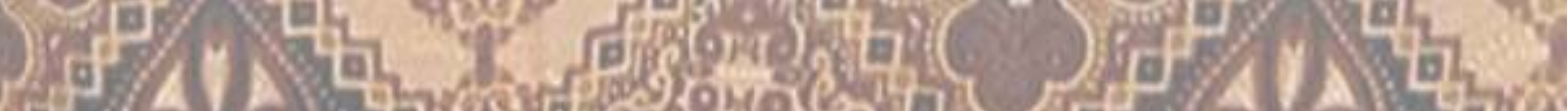
Sa

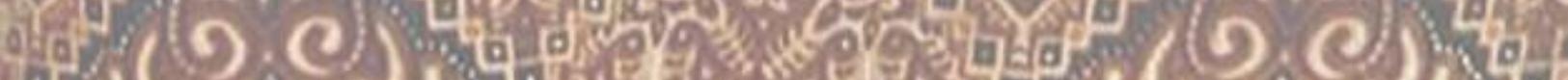
a

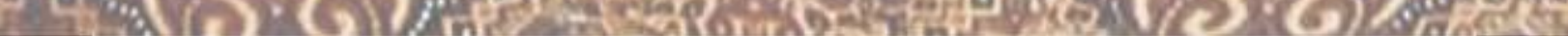


The central aim of the studies presented in this thesis was to find a way to ameliorate the problems encountered by medical students when transitioning from the preclinical to the clinical phase of the undergraduate curriculum. Many students feel ill prepared for training in the clinical environment and have difficulty applying knowledge and clinical skills learned during the preclinical curriculum in real patient care. It is a challenge for medical schools to address these problems and ensure that students are adequately prepared when they start their clerkships. This thesis explores the transition problems of students of the Faculty of Medicine - Gadjah Mada University (FM-GMU), Indonesia, proposes a solution to mitigate these problems, describes the implementation of early clinical experiences (ECE) as a possible solution, and presents an evaluation of the effects of ECE on students' experiences during the first clerkships.

\section{Chapter 1: General introduction}

This introductory chapter describes the structure of medical education worldwide, which general consists of a curriculum with two consecutive phases: a preclinical and a clinical phase. Next, the reason for focusing on clinical skills training is described. Preclinical skills training usually starts in the skills laboratory with the key aim to prepare students for the clinical phase. The skills laboratory provides training under standardized and safe conditions and with adequate facilities, such as rooms, equipment, teachers, and simulated patients. Furthermore, training in the skills laboratory is based on pre-defined standards. However, there are limitations to skills laboratory training. The standard procedures taught in the skills laboratory may differ from the procedures used by some clinicians in the clinical setting. Furthermore, not all aspects of clinical practice can be simulated in a laboratory, such as patients' clinical signs and symptoms (like liver enlargement) and interaction with other health professionals. These differences between training and clinical reality may present problems to students when they first start clinical training.

The introductory chapter also describes geographic and demographic characteristics of the setting of the studies, which were conducted in Indonesia, a developing country. Most previous studies on ECE have been conducted in industrialized countries, which usually differ considerably from developing countries, also with respect to the health care system and availability of human and financial resources. Those different characteristics may impact on possibilities for preclinical education. The following chapters present studies exploring the feasibility ofECE in undergraduate medical curricula in developing countries.

\section{Chapter 2: Exploring the transition problem}

Data on problems encountered by students during the transition from the preclinical to the clinical phase were collected during focus group discussions (FGDs) among FM-GMU students who had entered clerkships less than six months before participating in the study. Medical students in a developing country experience serious problems at the start of clinical training, especially in performing clinical 
skills learned in the skills laboratory on patients in the hospital. Those problems are related to differences between the skills laboratory and the clinical setting in educational climate, extensiveness of supervision, availability of equipment, and the confrontation with real rather than simulated patients. Particularly during their first clerkships, students have a strong sense of responsibility for their clinical performance, which is aggravated by fear of facing a lawsuit if they should harm a patient. These problems can affect students' clinical performance, especially during the first clerkships. Due to their lack confidence, students tend to remain passive observers for quite some time before they are ready to attempt to apply their skills in patient care.

Based on their early clerkship experiences, students asked for opportunities to practice in clinical settings prior to clinical training. They felt this would prepare them for the discrepancies between skills training and clinical reality and provide an opportunity to collaborate with other health workers. The students anticipated that preclinical training in a clinical setting would lead to improved preparedness for the clinical phase.

\section{Chapter 3: Selecting an appropriate setting for ECE}

The aim of the study presented in this chapter was to select the most appropriate clinical environment for ECE. The 'Dundee Ready Educational Environment Measure' (DREEM) questionnaire was used to collect quantitative data from students who had just entered clerkships. The results showed that primary health care $(\mathrm{PHC})$ centers were considered superior to other clinical settings, i.e. secondary health care (SHC) hospitals and tertiary health care (THC) hospitals. Qualitative data, obtained from students and clinical supervisors in the three settings, yielded more details about the suitability of PHC centers for preclinical skills training. Favorable conditions of PHC centers were: 1) adequate number of possibilities for 'hands on practice'; 2 ) sufficient numbers of patients; 3 ) variety of usually quite simple cases; 4) availability of clinical supervisors (usually GPs) who have sufficient time for teaching students; and 4) adequate facilities. The results indicated that PHC centers have clear advantages over SHC and THC for clinical skills training of preclinical students.

\section{Chapter 4: Exploring the readiness of patients in PHC centers for involvement in the training of preclinical students}

This study probed the opinions of patients in PHC centers about being seen by pre-clinical students under the supervision of a GP from the center. Immediately after their encounter with a preclinical student, patients' opinions about student involvement in their care were explored in an interview, in which eight questions were asked about the student's clinical competence and skills. The results indicated that patients were generally satisfied with the encounter and with the student's clinical performance. Some patients, on the other hand, reported weaknesses in the 
student's performance, such as a noticeable lack of confidence and anxiety, particularly during physical examination, and very brief explanations of the disorder, therapy, and prevention. However, patients acknowledged that the students were still learning and suggested that students should have more opportunities to practice their clinical skills.

\section{Chapter 5: Students' and supervisors' evaluations of ECE in PHC centers}

An experimental study was designed to compare the level of preparedness for clinical training of students trained in the skills laboratory and a PHC center (PT group) and students exclusively trained in the skills laboratory (NPT group). Clinical supervisors indicated that during attachments to a PHC center students improved in several areas that are relevant for clerkship preparation, such as confidence, selfdirected learning capabilities, and understanding of cooperation with other health professionals in the center. After the ECE program, students' preparedness for clinical training was measured in both groups by means of the 'Preparation for Hospital Practice Questionnaire' (PHPQ). The students in the PT group felt significantly better prepared compared to the students in the NPT group.

Somewhat surprisingly, the two groups had similar results on an 'Objective Structured Clinical Examination' (OSCE). This may be explained by the fact that some of the advanced clinical skills that are assessed in an OSCE, such as intubation and inserting an intravenous line, are hardly ever performed in a $\mathrm{PHC}$ center. Conversely, the more simple cases presented in $\mathrm{PHC}$ centers clearly had no negative effect on the PT students' OSCE results.

Both PT students and supervisors in PHC centers emphasized the importance of adequate preparation for the ECE program, including training of clinical supervisors to adhere to skills laboratory standards, coordination meetings between faculty and PHC center staff, and preparation of learning materials by the medical school. Furthermore, the medical school should consider the safety of all stakeholders involved, such as patients, students, and clinical supervisors. The PHC centers should also be protected against legal prosecution by patients if a medical error should occur due to the actions of a student. In order to ensure continuity of the collaboration between the medical faculty and the affiliated PHC centers, it was considered important that all stakeholders should benefit from the ECE program.

\section{Chapter 6: Evaluating the effect of ECE on the performance of students in their first clerkships}

After completing the preclinical phase, PT and NPT students started clinical training in a teaching hospital. This study explored and compared the first clerkship experiences of the two groups of students.

PT and NPT students participated in focus group discussions aimed at exploring, comparing, and confirming the students' experiences in applying their clinical skills in the hospital setting. The results indicated that PT students felt 
more confident. They were able to actively participate in clinical care from the very start of the first clerkship, because they had trained in a clinical setting and understood their role therein. By contrast, the NPT students reported experiencing the usual transition problems when they were challenged to apply their clinical skills. NPT students at first preferred to observe a physician executing diagnostic or therapeutic skills, and would only try to perform a procedure themselves when they felt more confident. After some time, when they had become used to the clinical setting, NPT students became as actively involved in clinical activities as PT students.

These findings show that students who participated in ECE can learn more efficiently during their first clerkship(s) and take more opportunities to perform skills, compared to students who did not take part in ECE. Considering the limitations of clerkships in duration and learning opportunities, this difference clearly enhances the effectiveness of the clinical phase.

\section{Chapter 7: Discussion}

The results of the studies presented in this thesis show that integration of preclinical skills training on campus with ECE in PHC centers can improve the preparation of preclinical students for clinical clerkships.

The studies have some limitations: 1)The studies were conducted in a single medical school, which may limit the applicability of the outcomes to other schools. To compensate for this weakness, data were collected from three sources: students, clinical supervisors, and patients. 2) The evaluation of the effects of ECE in PHC centers on students' clerkship performance was only based on students' personal judgments. In order to minimize subjectivity, the experiences of two groups of students were compared: students who had and students who had not participated in ECE.

Future studies should use additional methods to assess PT and NPT students' clerkship performance, e.g. 'Mini Clinical Evaluation Exercises' (mini-CEX) and 'Direct Observation of Procedural Skills' (DOPS) using multiple assessors. We would also encourage other medical schools, particularly in developing countries, to investigate the efficiency of ECE in preparing students for the clinical phase of the undergraduate curriculum.

Finally, we should consider the efficiency of the budget spent for this ECE program, especially in the context of a developing country. The experience at FMGMU has confirmed the feasibility of implementing a longitudinal ECE program. However, adequate preparation for the program and intensive coordination between university and PHC centers with respect to planning, delivery, and evaluation of the program are needed to ensure its continuity. Fair exchange and sharing of benefits between stakeholders (students, supervisors, PHC staff, and patients) may yield opportunities to reduce the cost of the program. 


\section{SAMENVATTING}

Centraal in de onderzoeken in dit proefschrift staat de zoektocht naar een methode om de problemen te verlichten die medische studenten ondervinden bij de transitie van de preklinische naar de klinische fase van de medische basisopleiding. Veel studenten voelen zich niet goed voorbereid op de klinische fase en ondervinden problemen bij het toepassen in de patiëntenzorg van de kennis en klinische vaardigheden die ze in de preklinische fase van het curriculum geleerd hebben. Het is een vitdaging voor het medisch onderwijs om deze problemen aan te pakken en ervoor te zorgen dat studenten goed voorbereid aan de coassistentschappen beginnen. De studies in dit proefschrift onderzochten de problemen van studenten aan de faculteit der geneeskunde van de Gadjah Mada University (FM-GMU) in Indonesië, leidden tot het voorstel om een programma in te voeren van vroege klinische ervaringen voor studenten en onderzochten de resultaten van dit programma door middel van een evaluatie van de effecten ervan op de ervaringen van studenten tijdens de eerste coassistentschappen.

\section{Hoofdstuk 1: Algemene inleiding}

Hoofdstuk 1 vormt de inleiding op dit proefschrift. Het beschrijft de meest gangbare structuur van de medische basisopleiding in verschillende delen van de wereld, die doorgaans bestaat uit een curriculum met een preklinische fase, gevolgd door een klinische fase. Vervolgens wordt uitgelegd waarom dit proefschrift gericht is op het vaardigheidsonderwijs. Het preklinisch vaardigheidsonderwijs wordt in het algemeen aangeboden in een skillslaboratorium met als hoofddoel studenten een goede voorbereiding te bieden op de coassistentschappen in de klinische fase. In het skillslaboratorium trainen studenten gestandaardiseerde vaardigheden in een veilige omgeving met goede voorzieningen, zoals trainingsruimtes, apparatuur, docenten en simulatiepatiënten. Trainingen worden gegeven volgens vooraf gedefinieerde standaarden. Training in een laboratorium kent echter beperkingen. De standaardprocedures die in het skillslaboratorium worden toegepast, kunnen verschillen van de procedures die gangbaar zijn in de kliniek. Het is bovendien onmogelijk om alle aspecten van de klinische praktijk, zoals symptomen en bevindingen bij patiënten (een vergrote lever bijvoorbeeld) en interactie met de staf in het ziekenhuis, na te bootsen in een laboratorium. Deze verschillen tussen het skillslaboratorium en de realiteit in de kliniek kunnen ertoe leiden dat studenten problemen ondervinden bij de aanvang van de klinische fase.

Hoofdstuk 1 bevat ook een beschrijving van de geografische en demografische kenmerken van Indonesië, het land waar de onderzoeken werden uitgevoerd. Indonesië is een ontwikkelingsland, terwijl de meeste bestaande onderzoeken naar vroege klinische ervaringen van studenten zijn uitgevoerd in 
ontwikkelde, geïndustrialiseerde landen. Tussen ontwikkelde en ontwikkelingslanden bestaan meestal grote verschillen in het gezondheidszorgsysteem en de beschikbaarheid van menskracht en financiële hulpbronnen, die van invloed zijn op de mogelijkheden van het preklinisch onderwijs. In de volgende hoofdstukken worden onderzoeken beschreven waarin de mogelijkheden werden onderzocht om in ontwikkelingslanden vroege klinische ervaringen in te voeren in de medische basisopleiding.

\section{Hoofdstuk 2: Een verkenning van problemen die zich voordoen bij de overgang} van de preklinische naar de klinische fase

Om gegevens te verzamelen over de problemen van studenten bij de overgang van de preklinische naar de klinische fase hebben studenten van de FMGMU deelgenomen aan focusgroepsdiscussies. De deelnemende studenten waren zes maanden voor het onderzoek begonnen met de coassistentschappen. Geneeskundestudenten in ontwikkelingslanden ervaren grote problemen bij aanvang van de coassistentschappen, vooral wanneer ze in het skillslaboratorium geleerde vaardigheden moeten uitvoeren bij patiënten in het ziekenhuis. De problemen vloeien voort uit verschillen tussen het skillslaboratorium en de kliniek met betrekking tot het onderwijsklimaat, de hoeveelheid begeleiding, de beschikbaarheid van apparaten en materialen en de confrontatie met echte patiënten, terwijl studenten in het skillslaboratorium vooral geoefend hebben met simulatiepatiënten. Vooral tijdens de eerste coassistentschappen ervaren studenten een sterk gevoel van verantwoordelijkheid voor hun klinische vaardigheden, dat nog versterkt wordt door vrees voor juridische consequenties als ze schade toebrengen aan een patiënt. Vooral tijdens de eerste coassistentschappen beïnvloeden deze problemen in hoge mate het klinisch handelen van studenten. Door gebrek aan zelfvertrouwen hebben studenten de neiging vrij lang passief te blijven observeren voordat ze zich voldoende zeker voelen om hun vaardigheden in de praktijk toe te passen.

Op basis van hun eerste ervaringen tijdens de coassistentschappen vroegen studenten om meer mogelijkheden om hun vaardigheden toe te passen in de praktijk, voorafgaand aan de klinische fase. Zij waren van mening dat dit hun een goede voorbereiding zou bieden op de klinische praktijk, de verschillen tussen vaardigheidsonderwijs in het skillslaboratorium en de praktijk in het ziekenhuis en de samenwerking met andere gezondheidszorgwerkers. De studenten verwachtten dat preklinische training in een klinische omgeving hen beter zou voorbereiden op de klinische fase.

\section{Hoofdstuk 3: De keuze van een geschikte omgeving voor vroege klinische ervaringen}

Het onderzoek dat in dit hoofdstuk beschreven wordt, werd uitgevoerd om te bepalen welke klinische omgeving het geschiktst was om preklinische 
studenten vroege klinische ervaringen te laten opdoen. Met behulp van de vragenlijst van de 'Dundee Ready Educational Environment Measure' (DREEM) werden kwantitatieve gegevens verzameld van studenten die net met de coassistentschappen begonnen waren. De resultaten lieten zien dat eerstelijns gezondheidscentra (primary care centers $(\mathrm{PHC})$ ) geschikter waren dan andere klinische omgevingen, zoals tweede- en derdelijns ziekenhuizen. De kwalitatieve gegevens van studenten en klinische begeleiders, die in elk van de drie klinische omgevingen verzameld werden, benadrukten de geschiktheid van eerstelijns gezondheidscentra voor preklinisch vaardigheidsonderwijs in de praktijk. Er waren verschillende factoren die maakten dat PHC's bij uitstekt geschikt waren voor vroege klinische ervaringen: 1 ) voldoende mogelijkheden om vaardigheden in de praktijk uit te voeren; 2) voldoende aantallen patiënten; 3) beschikbaarheid van voldoende variatie aan, meestal tamelijke eenvoudige, casuïstiek; 4) beschikbaarheid van klinisch begeleiders (meestal huisartsen) die voldoende tijd hebben voor onderwijs; en 4) geschikte voorzieningen. De resultaten gaven aan dat PHC's duidelijke voordelen boden voor preklinische vaardigheidstraining ten opzichte van de andere gezondheidszorginstellingen.

\section{Hoofdstuk 4: Een exploratief onderzoek naar de bereidheid van patiënten in PHC's om betrokken te worden bij de training van preklinische studenten}

In dit onderzoek werd de mening van patiënten in PHC's gepeild ten aanzien van de deelname van studenten aan de zorg onder supervisie van een huisarts van het centrum. Patiënten werden onmiddellijk na een contact met een student geïnterviewd over de betrokkenheid van studenten bij de zorg. Tijdens het interview werden acht vragen gesteld om de mening van de patiënten over de klinische competentie en de vaardigheden van de student te peilen. De resultaten lieten zien dat de patiënten over het algemeen tevreden waren over het consult en de vaardigheden van de student. Er waren echter ook patiënten die wezen op tekortkomingen in de vaardigheden van studenten. Dit betrof een merkbaar gebrek aan zelfvertrouwen en onzekerheid van de student, vooral bij het lichamelijk onderzoek, en het feit dat studenten te kort uitleg gaven over de aandoening, de behandeling en preventie. De patiënten waren zich er echter van bewust dat de studenten nog midden in hun leerproces zaten en zij stelden voor dat studenten meer gelegenheid moesten krijgen om hun vaardigheden te oefenen.

\section{Hoofdstuk 5: Evaluatie door studenten en begeleiders van vroege klinische ervaringen in eerstelijns gezondheidscentra}

Dit hoofdstuk beschrijft een experimenteel onderzoek waarin een vergelijking werd gemaakt tussen de mate van voorbereiding op de klinische fase van studenten die hadden deelgenomen aan vaardigheidstraining in zowel het skillslaboratorium als een gezondheidscentrum en studenten die uitsluitend 
getraind waren in het skillslaboratorium. De klinisch begeleiders gaven aan dat de studenten tijdens hun stage in het gezondheidscentrum vooruitgang boekten op verschillende gebieden die belangrijk zijn voor de voorbereiding op de coassistentschappen, zoals zelfvertrouwen, het vermogen tot zelfgestuurd leren en inzicht in samenwerking met andere gezondheidszorgwerkers in het centrum. Nadat de studenten de stage in het gezondheidscentrum hadden afgerond, werd de mate van voorbereiding op de coassistentschappen bij beide groepen studenten gemeten met behulp van de 'Preparation for Hospital Practice Questionnaire' (PHPQ). Het bleek dat de studenten die stage gelopen hadden in een gezondheidscentrum zich aanzienlijk beter voorbereid voelden op de coassistentschappen dan de studenten die uitsluitend in het skillslaboratorium getraind waren.

Een onverwacht resultaat was dat beide groepen vergelijkbare scores haalden op een stationstoets (Objective Structured Clinical Examination (OSCE)). Een mogelijke verklaring hiervoor is dat in het stationsexamen enkele meer gevorderde vaardigheden beoordeeld werden, zoals intuberen en het aanleggen van een intraveneus infuus, terwijl deze vaardigheden bijna nooit voorkwamen in het gezondheidscentrum. Omgekeerd was het ook zo dat het feit dat de studenten in het gezondheidscentrum hoofdzakelijk patiënten met eenvoudige klachten gezien hadden geen negatief effect had op de examenresultaten van deze studenten.

Zowel de studenten die stage hadden gelopen in een gezondheidscentrum als hun begeleiders benadrukten het belang van goede voorbereiding op de stage. Dit behelsde training van klinisch begeleiders in de toepassing van de vaardigheidsstandaarden die gehanteerd werden in het skillslaboratorium, bijeenkomsten om de activiteiten van docenten in het skillslaboratorium en staf van het gezondheidscentrum te coördineren en het beschikbaar stellen van leermiddelen door de universiteit. Het werd ook van belang geacht dat de faculteit een garantie bood voor de veiligheid van alle betrokken partijen, patiënten, studenten en klinisch begeleiders. De gezondheidscentra moesten ook gevrijwaard worden van juridische vervolging door patiënten bij medische fouten tengevolge van het handelen van een student. Er werd gewezen op het belang van het waarborgen van de continuïteit van de samenwerking tussen de medische faculteit en de geaffilieerde gezondheidscentra. Hiertoe dienden maatregelen genomen te worden om ervoor te zorgen dat alle betrokkenen partijen voordeel zouden hebben van deelname aan het stageprogramma.

\section{Hoofdstuk 6: Evaluatie van het effect van vroege klinische ervaringen op de prestaties van studenten tijdens de eerste coassistentschappen}

$\mathrm{Na}$ het afronden van de preklinische fase van het curriculum begonnen de studenten aan de klinische fase van het curriculum. Dit gold voor de groep studenten die vaardigheden hadden getraind in zowel een gezondheidscentrum 
als het skillslaboratorium en voor de groep die vitsluitend trainingen in het skillslaboratorium had gevolgd. In dit hoofdstuk werden de ervaringen van beide groepen studenten onderzocht.

Hiertoe namen beide groepen studenten deel aan focusgroepsbijeenkomsten waarin zij hun ervaringen bespraken. Dit had tot doel de ervaringen van de studenten met het toepassen van vaardigheden in de klinische praktijk in het ziekenhuis in kaart te brengen, te vergelijken en te bevestigen. De studenten die in het gezondheidscentrum hadden getraind bleken meer zelfvertrouwen te hebben ten aanzien van hun vaardigheden. Vanaf de start van hun eerste coassistentschap waren zijn in staat actief deel te nemen aan de patiëntenzorg, doordat zij ervaring hadden opgedaan in een klinische omgeving en begrepen wat hun rol in de zorg was. Daarentegen gaven de studenten die alleen in het skillslaboratorium getraind waren aan dat zij de gebruikelijke problemen ondervonden bij het toepassen van hun vaardigheden in de klinische praktijk. Zij gaven er de voorkeur aan eerst alleen te observeren terwijl een arts diagnostische of therapeutische vaardigheden uitvoerde en waren pas bereid om zelf vaardigheden uit te voeren als ze meer zelfvertrouwen hadden gekregen. Na enige tijd waren zij gewend aan de klinische omgeving en namen zij in dezelfde mate deel aan klinische activiteiten als de studenten die de stage in het gezondheidscentrum gevolgd hadden.

Deze bevindingen laten zien dat vroege klinische ervaringen studenten beter voorbereiden op het leren tijdens de eerste coassistentschappen en hen beter in staat stellen gebruik te maken van leermogelijkheden ten aanzien van vaardigheden vergeleken met studenten die vitsluitend getraind zijn in het skillslaboratorium. Gezien de beperkingen van coassistentschappen in lengte en leermogelijkheden, biedt de stage in een gezondheidscentrum een duidelijk voordeel doordat studenten effectiever gebruik kunnen maken van leermogelijkheden bij de aanvang van de klinische fase.

\section{Hoofdstuk 7: Discussie}

De resultaten van de onderzoeken in het kader van dit proefschrift laten zien dat geïntegreerde vaardigheidstraining in een skillslaboratorium en een gezondheidscentrum studenten beter voorbereidt op de klinische fase.

De onderzoeken hebben een aantal beperkingen: 1) Ze zijn allemaal uitgevoerd in dezelfde medische faculteit en dit kan betekenen dat de uitkomsten niet zonder meer generaliseerbaar zijn naar andere faculteiten. Om deze zwakte te compenseren zijn gegevens verzameld van verschillende groepen belanghebbenden: studenten, klinische begeleiders en patiënten. 2) De resultaten met betrekking tot de effecten van vroege klinische ervaringen in eerstelijns gezondheidscentra op de prestaties van studenten tijdens de coassistentschappen zijn uitsluitend gebaseerd op het persoonlijke oordeel van de studenten. Teneinde de subjectiviteit te verminderen zijn de ervaringen van twee groepen studenten 
vergeleken: studenten die alleen getraind hadden in een skillslaboratorium en studenten die daarnaast stage hadden gelopen in een gezondheidscentrum.

Verder onderzoek dient ook gebruik te maken van andere methoden om het functioneren van studenten tijdens de coassistentschappen te beoordelen. Methoden die hiervoor in aanmerking komen, zijn korte klinische beoordelingen op grond van directe observatie van procedurele vaardigheden, bijvoorbeeld aan de hand van 'Mini Clinical Evaluation Exercises' (mini-CEX). Deze beoordelingsmethoden dienen uitgevoerd te worden door een aantal verschillende beoordelaars. Tevens bevelen wij aan de effectiviteit van vroege klinische ervaringen als voorbereiding op de klinische fase ook te onderzoeken in andere medische faculteiten, met name faculteiten in ontwikkelingslanden.

Het verdient het aanbeveling dat er, vooral in ontwikkelingslanden, onderzoek wordt gedaan naar de besteding van het beschikbare budget voor het programma van vroege klinische ervaringen. De ervaringen in FM-GMU hebben de uitvoerbaarheid aangetoond van een longitudinaal programma van vroege klinische ervaringen. Als voorwaarde voor de continuïteit van het programma is een goede voorbereiding op het programma essentieel, evenals intensieve coördinatie tussen universiteit en de deelnemende gezondheidscentra met betrekking tot planning, uitvoering en evaluatie van het programma. Ook dienen alle belanghebbenden (studenten, begeleiders, staf in het gezondheidscentrum en patiënten) merkbaar profijt te hebben van de voordelen van het programma, waardoor de kosten van het programma beperkt kunnen worden. 


\section{RINGKASAN}

Tujuan utama dari penelitian yang disajikan dalam disertasi ini adalah untuk menemukan cara untuk mengatasi masalah yang dihadapi oleh mahasiswa kedokteran pada saat transisi dari fase pra-klinis memasuki fase klinis pada kurikulum pendidikan dokter. Banyak mahasiswa merasa tidak siap untuk memasuki pelatihan dalam lingkungan klinis / koasistensi, dan mengalami kesulitan menerapkan pengetahuan dan keterampilan klinis yang pernah dipelajari selama pendidikan pra-klinis dalam merawat pasien. Ini merupakan tantangan bagi fakultas-fakultas kedokteran untuk mengatasi masalah tersebut dan memastikan bahwa mahasiswa cukup siap ketika mereka memasuki pendidikan profesi atau koasistensi. Tesis ini membahas masalah transisi dari fase pra-klinis menuju fase klinis pada mahasiswa Fakultas Kedokteran - Universitas Gadjah Mada (FK-UGM), Indonesia, dan mengusulkan sebuah solusi untuk mengurangi masalah, menggambarkan pelaksanaan pengalaman klinis dini (PKD) sebagai solusi yang memungkinkan, dan menyajikan evaluasi efek PKD pada pengalaman mahasiswa di awal koasistensinya.

\section{Bab 1: Pengantarumum}

Bab pendahuluan ini menjelaskan struktur kurikulum dunia pendidikan kedokteran yang secara umum terdiri dari dua fase berurutan: fase pra-klinis dan klinis. Selanjutnya, menjelaskan alasan mengapa tesis ini difokuskan pada pelatihan keterampilan klinis. Pelatihan keterampilan pra-klinis biasanya dimulai di laboratorium keterampilan medis (Skills Lab) dengan tujuan kunci untuk mempersiapkan mahasiswa memasuki fase klinis. Laboratorium keterampilan medis memberikan pelatihan dalam kondisi standar, aman, dan dengan fasilitas yang memadai, seperti ruangan, peralatan medis, instruktur, dan pasien simulasi. Pelatihan di laboratorium keterampilan medis disusun berdasarkan pra-standar yang telah ditetapkan, namun ternyata ada keterbatasan dalam pelatihan laboratorium tersebut. Sebagai contoh, prosedur standar yang diajarkan dalam laboratorium ada kemungkinan berbeda dengan prosedur yang digunakan oleh dokter dalam situasi klinis yang sebenarnya. Selain itu, tidak semua aspek dalam praktek klinis dapat disimulasikan di laboratorium, seperti tanda-tanda dan gejalagejala klinis pasien (contoh pembesaran hati), serta interaksi dengan tenaga kesehatan lainnya. Perbedaan-perbedaan antara pelatihan dan realitas klinis tersebut dapat menimbulkan masalah bagi para mahasiswa ketika mereka pertama mulaibelajar difase klinis.

Bab pendahuluan ini juga menggambarkan karakteristik geografis dan demografis dari tempat penelitian yang dilaksanakan di Indonesia selaku negara yang sedang berkembang. Kebanyakan penelitian sebelumnya mengenai PKD dilakukan di negara-negara maju (industri), yang biasanya sangat berbeda situasinya dengan negara-negara yang sedang berkembang, terutama dalam hal sistem perawatan kesehatan, ketersediaan sumber daya manusia, dan keuangan. 
Karakteristik yang berbeda tersebut dapat berdampak pada pendidikan pra-klinis. Beberapa bab berikutnya menyajikan penelitian yang mengeksplorasi kelayakan PKD dalam kurikulum sarjana kedokteran pada negara berkembang.

\section{Bab 2: Mengeksplorasi masalah transisi}

Data tentang masalah yang dihadapi oleh mahasiswa selama masa transisi dari fase pra-klinis memasuki fase klinis dikumpulkan menggunakan diskusi kelompok terfokus (FGD) dari mahasiswa FK UGM yang telah memasuki koasistensi kurang dari enam bulan pada saat berpartisipasi dalam penelitian ini. Mahasiswa kedokteran di negara yang sedang berkembang ternyata mempunyai pengalaman mendapatkan masalah yang serius pada awal pendidikan klinis, terutama dalam melakukan pelatihan keterampilan klinis yang sebelumnya telah dipelajari di laboratorium keterampilan medis kepada pasien di rumahsakit. Masalah-masalah tersebut terkait dengan perbedaan antara situasi laboratorium keterampilan medis dengan pendidikan klinis, seperti; intensitas bimbingan, ketersediaan peralatan, dan perbedaan antara pasien sesungguhnya dengan pasien simulasi. Khususnya pada stase koasistensi pertama, mahasiswa merasakan memiliki beban tanggung jawab besar untuk kinerja klinis mereka, yang diperberat dengan rasa takut menghadapi gugatan hukum jika mereka melakukan kesalahan yang membahayakan pasien. Masalah-masalah tersebut tentu dapat mempengaruhi kinerja klinis mahasiswa, terutama selama stase koasisten pertama. Oleh karena rasa percaya diri yang kurang, mahasiswa cenderung menjadi pengamat pasif untuk beberapa saat sebelum mereka siap mencoba untuk menerapkan keterampilan klinis mereka dalam perawatan pasien.

Berdasarkan pengalaman mereka diawal koasisten, mahasiswa minta diberikan kesempatan untuk dapat berlatih dalam situasi klinis sebelum memasuki pendidikan klinis. Mahasiswa merasa kesempatan tersebut akan mempersiapkan mereka untuk dapat menghadapi perbedaan antara pelatihan keterampilan di laboratorium dengan kenyataan klinis, dan memberikan kesempatan kepada mereka berlatih kolaborasi dengan profesi kesehatan lainnya. Para mahasiswa memilih melakukan antisipasi dengan mendapatkan pelatihan keterampilan dalam lingkungan klinis pada fase pra-klinis untuk meningkatkan kesiapan mereka memasuki fase klinis.

\section{Bab 3: Memilih lingkungan klinis yang sesuai untuk PKD}

Tujuan dari penelitian yang disajikan dalam bab ini adalah untuk memilih lingkungan klinis yang paling tepat untuk PKD. Kuesioner 'Dundee Ready Educational Environment Measure' (DREEM) digunakan untuk mengumpulkan data kuantitatif dari mahasiswa yang baru saja memasuki koasistensi. Hasil penelitian menunjukkan bahwa pusat pelayanan kesehatan primer (Pusat Kesehatan Masyarakat = Puskesmas) dianggap unggul dibandingkan lingkungan klinis lainnya, yaitu pusat pelayanan kesehatan sekunder (Rumah Sakit Umum Daerah = RSUD), dan pusat 
pelayanan kesehatan tersier (Rumah Sakit Umum Pusat = RSUP). Selanjutnya, data kualitatif yang diperoleh dari mahasiswa dan supervisor klinis dari tiga lingkungan klinis, menghasilkan rincian lebih lanjut mengenai kesesuaian Puskesmas sebagai tempat pelatihan keterampilan pra-klinis. Kondisi menguntungkan dari Puskesmas adalah: 1) jumlah yang memadai untuk mahasiswa dapat 'praktek langsung'; 2) jumlah pasien yang cukup; 3) kasus yang ada biasanya cukup sederhana; 4) ketersediaan supervisor klinis (biasanya dokter umum) yang memiliki cukup waktu untuk melatih mahasiswa, dan 4) tersedianya fasilitas yang memadai. Hasil penelitian menunjukkan bahwa Puskesmas memiliki keunggulan yang lebih dari SHC dan THC untuk pelatihan keterampilan medis mahasiswa pra-klinis.

\section{Bab 4: Mengeksplorasi kesiapan pasien di Puskesmas yang terlibat dalam pelatihan mahasiswa pra-klinis}

Penelitian ini menggali pendapat pasien di Puskesmas dalam berinteraksi dengan mahasiswa pra-klinis di bawah pengawasan seorang dokter Puskesmas. Segera setelah berinteraksi dengan seorang mahasiswa pra-klinis, pendapat pasien dieksplorasi dalam sebuah wawancara mengenai keterlibatan mahasiswa dalam pelayanan kesehatan kepada mereka, menggunakan delapan pertanyaan tentang kompetensi dan keterampilan klinis mahasiswa. Hasil penelitian menunjukkan bahwa pasien secara umum puas dengan interaksi dan kinerja klinis mahasiswa. Di sisi lain, beberapa pasien juga melaporkan kelemahan dalam kinerja mahasiswa, seperti terlihat kurang percaya diri dan cemas, khususnya selama melakukan pemeriksaan fisik, selain itu penjelasan mengenai keluhan pasien, terapi, dan pencegahan penyakit terkesan sangat singkat. Namun, pasien mengakui bahwa mahasiswa masih dalam proses belajar, sehingga mereka menyarankan bahwa mahasiswa harus memiliki lebih banyak kesempatan untuk berlatih keterampilan klinis.

\section{Bab 5: Evaluasi PKD di Puskesmas oleh mahasiswa dan supervisor klinis}

Sebuah penelitian eksperimental dirancang untuk membandingkan tingkat kesiapan mahasiswa untuk memasuki pendidikan klinis, dari mahasiswa yang dilatih di laboratorium keterampilan medis dan Puskesmas (kelompok PT), dengan mahasiswa yang dilatih secara eksklusif di laboratorium keterampilan medis (kelompok NPT). Supervisor klinis menunjukkan bahwa mahasiswa selama berlatih di Puskesmas menunjukkan peningkatan di beberapa bidang yang relevan untuk persiapan koasistensi, seperti; kepercayaan diri, kemampuan menentukan arah belajar (self-directed learning), dan pemahaman untuk bekerjasama dengan tenaga kesehatan lain di Puskesmas. Setelah menyelesaikan program PKD, tingkat kesiapan mahasiswa untuk memasuki pendidikan klinis pada kedua kelompok diukur dengan menggunakan 'Preparation for Hospital Practice Questionaire' (PHPQ). Hasilnya, mahasiswa dalam kelompok PT secara signifikan merasa lebih siap dibandingkan dengan mahasiswa dalam kelompok NPT. 
Sedikit mengherankan, kedua kelompok tersebut ternyata memiliki hasil ujian 'Objective Structured Clinical Examination' (OSCE) yang serupa. Namun, hal ini dapat dijelaskan melalui fakta bahwa beberapa keterampilan klinis yang dinilai dalam ujian OSCE, seperti; intubasi dan memasukkan infus intravena, memang hampir tidak pernah dilakukan di Puskesmas. Selain itu, kasus sederhana yang disajikan di Puskesmas ternyata tidak memiliki efek negatif pada hasil OSCE mahasiswa PT.

Mahasiswa dari kelompok PT dan supervisor klinis di Puskesmas menekankan pentingnya persiapan yang memadai untuk program PKD, termasuk pelatihan supervisor klinis agar mematuhi standar dari laboratorium keterampilan medis, rapat koordinasi antara fakultas dan staff Puskesmas, serta persiapan bahan pembelajaran oleh fakultas kedokteran. Selanjutnya, fakultas kedokteran harus memperhatikan keselamatan semua pihak yang terlibat, seperti; pasien, mahasiswa, dan supervisor klinis. Institusi Puskesmas juga harus dilindungi terhadap tuntutan hukum dari pasien jika terjadi kesalahan medis yang disebabkan oleh karena kesalahan tindakan mahasiswa. Dalam rangka menjamin kelangsungan kolaborasi antara fakultas kedokteran dan Puskesmas, penting diperhitungkan bahwa semua pihak sebaiknya mendapatkan keuntungan dari program PKD tersebut.

\section{Bab 6: Mengevaluasi pengaruh PKD terhadap kinerja mahasiswa pada stase koasisten pertama}

Setelah menyelesaikan tahap pra-klinis, mahasiswa PT dan NPT memulai stase klinis di rumahsakit pendidikan. Penelitian ini mengeksplorasi dan membandingkan pengalaman pertama magang dari dua kelompok mahasiswa tersebut.

Mahasiswa PT dan NPT berpartisipasi dalam diskusi kelompok terfokus (FGD) yang ditujukan untuk mengeksplorasi, membandingkan, dan mengkonfirmasikan pengalaman mereka dalam menerapkan keterampilan klinis di rumahsakit. Hasil penelitian menunjukkan bahwa mahasiswa PT merasa lebih percaya diri. Mereka mampu berpartisipasi aktif dalam perawatan klinis pasien sejak dari awal stase pertama karena sebelumnya mereka telah terlatih dalam lingkungan klinis dan memahami peran mereka didalamnya. Sebaliknya, secara umum mahasiswa NPT dilaporkan mengalami masalah transisi ketika mereka ditantang untuk dapat menerapkan keterampilan klinis mereka kepada pasien. Mahasiswa NPT pada awalnya lebih suka mengamati dokter (supevisor) melakukan keterampilan diagnostik atau terapeutik, dan hanya akan mencoba untuk melakukan prosedur klinis tersebut ketika mereka sudah merasa percaya diri. Setelah beberapa saat, ketika mereka telah menjadi terbiasa dengan lingkungan klinis, mahasiswa NPT menjadi aktif terlibat dalam kegiatan klinis, sama seperti mahasiswa PT.

Temuan ini menunjukkan bahwa mahasiswa yang berpartisipasi dalam PKD dapat belajar lebih efisien selama stase pertama mereka dan mengambil lebih 
banyak kesempatan untuk dapat melakukan keterampilan klinis dibandingkan dengan mahasiswa NPT yang tidak terlibat dalam PKD. Mengingat keterbatasan durasi waktu dan kesempatan belajar dalam koasistensi, perbedaan tersebut diatas jelas meningkatkan efektivitas dari fase pendidikan klinis.

\section{Bab 7: Diskusi}

Hasil penelitian yang disajikan dalam tesis ini menunjukkan bahwa integrasi pelatihan keterampilan pra-klinis di kampus dengan PDK di Puskesmas dapat meningkatkan kesiapan mahasiswa pra-klinis untuk memasuki fase klinis.

Namun penelitian ini memiliki beberapa keterbatasan: 1) Penelitian ini dilakukan pada satu fakultas kedokteran, yang kemungkinan dapat membatasi penerapan hasilnya pada fakultas kedokteran lain. Untuk mengimbangi kelemahan ini, data yang dikumpulkan berasal dari tiga sumber: mahasiswa, supervisor klinis, dan pasien. 2) Evaluasi dampak PDK di Puskesmas pada kinerja mahasiswa yang magang hanya berdasarkan pada penilaian pribadi mahasiswa. Dalam rangka untuk meminimalkan subjektivitas, pengalaman dari dua kelompok mahasiswa dibandingkan: mahasiswa yang telah, dengan yang tidak berpartisipasi dalam PKD. Penelitian berikutnya harus menggunakan metode tambahan untuk menilai kinerja mahasiswa PT dan NPT, misalnya 'Mini Clinical Evaluation Exercises' (mini-CEX) dan 'Direct Observation of Procedural Skills' (DOPS) dengan menggunakan beberapa penilai. Peneliti juga akan mendorong sekolah-sekolah medis lainnya, khususnya dari negara berkembang, agar bersedia meneliti efisiensi PDK dalam mempersiapkan mahasiswa untuk melaksanakan fase klinis dari kurikulum pendidikan dokter.

Akhirnya juga harus dipertimbangkan efisiensi anggaran yang digunakan untuk program PDK, terutama dalam konteks negara berkembang. Pengalaman di FK-UGM telah mengkonfirmasi kelayakan pelaksanaan program PDK secara longitudinal. Namun, persiapan yang memadai untuk program dan koordinasi yang intensif antara Universitas dan Puskesmas sehubungan dengan perencanaan, pengiriman, dan evaluasi program yang diperlukan untuk menjamin keberlangsungan program ini. Pertukaran dan pembagian manfaat yang adil bagi semua pihak (mahasiswa, supervisor, staf Puskesmas, dan pasien) dapat menghasilkan peluang yang memungkinkan untuk mengurangi biaya program tersebut. 


\section{Acknowledgements}

First of all, I would like to acknowledge Allah SWT, for the blessing to me on working and finishing this PhD study. In this section, I also would like to acknowledge and mention everybody and all institutions and funders who supported me for finishing my PhD studies. However, the space of this book and my brain's memory are very limited. Therefore, in the beginning of this section, I would like to apologize if there is someone or any institution that contributed to my studies but was left out of this section. I realize that without their support I would not have been able to finish this study, so for that reason I appreciate all their helps whatever it was and therefore also dedicate my thesis to all. I acknowledge,

16. My wife Ade which currently pregnant for my second child, my daughter Camilla, and my families who are always around and give their supports and encouraged me to finish my study on time.

Faculty of Medicine Gadjah Mada University and Maastricht University in giving me the opportunity to my doctorate study, for strengthening the institution's capacity building in medical education field of study for the future.

My promotor Prof. Albert Scherpbier, who always gave positive feedback to motivate me to make progress and who made me feel like everything becoming easier. My co-promotor Gerard Majoor who was always beside me, gave close supervision and guidance on my writing, English grammar, and gave detailed feedback, which was very useful for me to continue my work. Then, last but not least, Prof. Soenarto Sastrowijoto, who served as my role model on working as an educator, who was always asking for my progress, and gave support during my study. I am deeply thankful for their supervision, I learned a lot from all of them.

The review committee for their willingness to review my thesis; Prof. Cees van der Vleuten, Prof. Tim Dornan, Prof. Arie Nieuwenhuizen Kruseman, Dr. Diana Dolmans, and Dr. Jan van Dalen. Thank you for your help during my study, and the review.

The Dutch NPT project (NUFFIC) for the full financial support for my study. Especially my thanks go to Dr. Titi Savitri (UGM), Dr. Geraldine van Kasteren (UM), and Prof. Rein Zwierstra (RUG) for their concern and attention for my study, also the NPT staffs, Hennie Sijen, Evi Viva Evana, and all friends in the MUNDO secretariat for the support.

Mrs. Mereke Gorsira and Ms. Dian Rachmawati for the English editing, and also Albert's secretaries, Denise Soeters and Anouk Kerkhofs for arranging meetings.

Skills Laboratory and Department of Medical Education, Faculty of Medicine of Gadjah Mada University (FM-UGM), for their support and facilities during my studies, and seniors, Dr. Gandes Retno Rahayu, Dr. Bambang Djarwoto, and friends, for their help and advices related to my studies, all the office staffs; 
Mrs. Fransisca Irmawati, Mrs. Dany Lukita, and friends, for help and facilitatation of my studies.

My colleagues, Dr. Soewono and Dr. Widya Wasityastuti for data collection in the hospitals settings. My students assistants, Bina Muntafia Dewintari, Pande Putu Adhyka, and friends who were highly motivated to help me in the data collection process, and also PHC supervisors for the collaboration.

My teachers and colleagues in UM - Marijke Kruithof, Pie Bartholomeus, Prof. Job Metsemakers, Robbert Duvivier, and Renée Stalmeijer, for their motivating interest, SHE secretariat staffs, Lilian Swaen, and Nicky Verleng, and friends in the secretariat for their assistance.

2. To all Indonesian students in PPI Maastricht and Indonesian families who live in Maastricht, who were always around accompanying me during my stays in Maastricht, to give support and happiness, which helped me a lot not to become home sick.

Finally, I also acknowledge the other parties that can not mentioned one by one. Finishing this PhD study is not the final step of my journey, it is only a small parts of journey in my life. Hopefully, I can use my knowledge and skills acquired during this $\mathrm{PhD}$ study to give benefits to the communities and sciences. I need more collaboration and supports in the future to become successful in finishing my journey. 


\section{SHE dissertations series}

In the SHE Dissertation Series dissertations are published of PhD candidates from the School of Health Professions Education (SHE) who defended their PhD thesis at Maastricht University. The most recent ones are listed below. For more information go to: www.maastrichtuniversity.nl/she.

Stalmeijer, R. E. (07-07-2011) Evaluating ClinicalTeaching through Cognitive Apprenticeship. Malling, B.V.G. (01-07-2001) Managing word-based postgraduate medical education in clinical departments

Veldhuijzen, J.W. (17-06-2011) Challenging the patient-centred paradigm: designing feasible guidelines for doctor patient communication.

Van Blankenstein, F. (18-05-2011) Elaboration during problem-based, small group discussion: A new approach to study collaborative learning.

Van Mook, W. (13-05-2011) Teaching and assessment of professional behavior: Rhetoric and reality.

De Leng, B. (8-12-2009). Wired for learning. How computers can support interaction in small group learning in higher education.

Maiorova, T. (29-05-2009). The role of gender in medical specialty choice and general practice preferences.

Bokken, L. (04-03-2009). Innovative use of simulated patients for educational purposes.

Wagenaar, A. (18-09-2008). Learning in internships. What and how students learn from experience.

Driessen, E. (25-06-2008). Educating the self-critical doctor. Using portfolio to stimulate and assess medical students' reflection.

Derkx, H. (18-06-2008). For your ears only. Quality of telephone triage at out-of-hours centres in the Netherlands.

Niessen, Th. (30-11-2007). Emerging epistemologies: making sense of teaching practice.

Budé, L. (05-10-2007). On the improvement of students' conceptual understanding in statistics education.

Niemantsverdriet, S. (26-07-2007). Learning from international internships: A reconstruction in the medical domain.

Marambe, K. (20-06-2007). Patterns of student learning in medical education - A Sri Lankan study in traditional curriculum.

Pleijers, A. (19-01-2007). Tutorial group discussion in problem-based learning.

Sargeant, J. (21-09-2006). Multi-source feedback for physician learning and change.

Dornan, T. (12-06-2006). Experience-based learning.

Wass, V. (12-05-2006). The assessment of clinical competence in high stakes examinations.

Prince, K. (21-04-2006). Problem-based learning as a preparation for professional practice. 


\section{ICO dissertation series}

In the ICO Dissertation Series dissertations are published of graduate students from faculties and institutes on educational research within the following universities: Eindhoven University of Technology, Leiden University, Maastricht University, Open University of the Netherlands, University of Amsterdam, University of Groningen, University of Twente, Utrecht University, VU University Amsterdam, and Wageningen University (and formerly Radboud University Nijmegen and Tilburg University). Below is a list of the most recent dissertations For more information go to: www.ou.nl/ico.

179. Munneke-de Vries, E.L. (11-01-2008). Arguing to learn: Supporting interactive argumentation through computer-supported collaborative learning. Utrecht: Utrecht University.

180. Nijveldt, M.J. (16-01-2008). Validity in teacher assessment. An exploration of the judgement processes of assessors. Leiden: Leiden University.

181. Jonker, H.G. (14-02-2008). Concrete elaboration during knowledge acquisition. Amsterdam:VUUniversityAmsterdam.

182. Schuitema, J.A. (14-02-2008). Talking about values. A dialogue approach to citizenship education as an integral part of history classes. Amsterdam: University of Amsterdam.

183. Janssen, J.J.H.M. (14-03-2008). Using visualizations to support collaboration and coordination during computer-supported collaborative learning. Utrecht: Utrecht University.

184. Honingh, M.E. (17-04-2008). Beroepsonderwijs tussen publiek en privaat: Een studie naar opvattingen en gedrag van docenten en middenmanagers in bekostigde en nietbekostigde onderwijsinstellingen in het middelbaar beroepsonderwijs. Amsterdam: University of Amsterdam.

185. Baartman, L.K.J. (24-04-2008). Assessing the assessment: Development and use of quality criteria for competence assessment programmes. Utrecht: Utrecht University.

186. Corbalan Perez, G. (25-04-2008). Shared control over task selection: Helping students to select their own learning tasks. Heerlen: Open University of the Netherlands.

187. Hendrikse, H.P. (22-05-2008). Wiskundig actief: Het ondersteunen van onderzoekend leren in het wiskunde onderwijs. Enschede: University of Twente.

188. Moonen, M.L.I. (26-09-2008). Testing the multi-feature hypothesis: Tasks, mental actions and second language acquisition. Utrecht: Utrecht University.

189. Hooreman, R.W. (18-11-2008). Synchronous coaching of the trainee teacher: An experimental approach. Eindhoven: Eindhoven University ofTechnology.

190. Bakker, M.E.J. (02-12-2008). Design and evaluation of video portfolios: Reliability, generalizability, and validity of an authentic performance assessment for teachers. Leiden: Leiden University.

191. Kicken, W. (12-12-2008). Portfolio use in vocational education: Helping students to direct theirlearning. Heerlen: Open University of the Netherlands.

192. Kollöffel, B.J. (18-12-2008). Getting the picture: The role of external representations in simulation-based inquiry learning. Enschede:University of Twente. 
193. Walraven, A. (19-12-2008). Becoming a critical websearcher: Effects of instruction to foster transfer. Heerlen: Open University of the Netherlands.

194. Radstake, H. (14-05-2009).Teaching in diversity: Teachers and pupils about tense situations in ethnically heterogeneous classes. Amsterdam: University of Amsterdam.

195. Du Chatenier, E. (09-09-2009). Open innovation competence: Towards a competence profile for interorganizational collaboration in innovation teams. Wageningen: Wageningen University.

196. Van Borkulo, S.P. (26-06-2009). The assessment of learning outcomes of computer modelling in secondary science education. Enschede: University of Twente.

197. Handelzalts, A. (17-09-2009). Collaborative curriculum development in teacher design teams. Enschede: University ofTwente.

198. Nievelstein, F.E.R.M. (18-09-2009). Learning law: Expertise differences and the effect of instructional support. Heerlen: Open University of the Netherlands.

199. Visser-Wijnveen, G.J. (23-09-2009). The research-teaching nexus in the humanities: Variations among academics. Leiden: Leiden University.

200. Van der Rijst, R.M. (23-09-2009). The research-teaching nexus in the sciences: Scientific research dispositions and teaching practice. Leiden: Leiden University.

201. Mainhard, M.T. (25-09-2009). Time consistency in teacher-class relationships. Utrecht: Utrecht University.

202. Van Ewijk, R. (20-10-2009). Empirical essays on education and health. Amsterdam: University of Amsterdam.

203. Seezink, A. (18-11-2009). Continuing teacher development for competence-based teaching. Tilburg:Tilburg University.

204. Rohaan, E.J. (09-12-2009). Testing teacher knowledge for technology teaching in primary schools. Eindhoven: Eindhoven University ofTechnology.

205. Kirschner, F.C. (11-12-2009). United brains for complex learning. Heerlen: Open University of the Netherlands.

206. Wetzels, S.A.J. (18-12-2009). Individualized strategies for prior knowledge activation. Heerlen: Open University of the Netherlands. 


\section{Curriculum vitae}

Widyandana (Doni) was born March $26^{\text {th }}, 1979$, in Yogyakarta city, Indonesia. He commenced his study of medicine in 1997 at the Faculty of Medicine of Gadjah Mada University (FM-GMU), Yogyakarta, Indonesia, and received his MD degree in 2004. Subsequently, he started his master program in Health Professions Education (MHPE), Maastricht University, the Netherlands in 2005-2007, then continued with his PhD program officially from January 2008 addressing integration undergraduate clinical skills training between skills laboratory and primary health care settings to prepare students for entering their clerkship.

He has been actively involved in medical education field since he was a bachelor-student, as an assistant in the sub-department of Medical Education (SPP) of FM-GMU. Then, he continued his career as a staff member in the Skills Laboratory in 2004, and joined the Department of Medical Education in 2006. During his career, he was responsible for managing skills laboratory's equipment, simulated patients, and now he is coordinating skills training activities for $4^{\text {th }}$ year students, in particular the transition program between pre-clinical and the clinical phase. He is involved in conducting and reporting on research, at the national and international level. Furthermore, he is also deeply involved in several education projects and gives courses in innovation of medical education for medical teachers in Indonesia.

$\mathrm{He}$ is interested in conducting research in the area of undergraduate clinical skills training which focuses on innovation of the use of simulated patients and community based education. He has joined international collaboration in the medical education field, especially for the issues mentioned above.

In additions, as a medical doctor, he is also active as a social worker in the communities supported by NGO's. He plays a role as a volunteer doctor in a teenage reproductive health clinic, and has given health promotions in radio broadcasts and local news papers since 1999 .

\section{List of International Presentation and Publications during PhD study (2008-2011)}

1. Widyandana, Wiyadi N, Lucassen P. 2009. Challenges in medical education - based on second year progress family medicine course in Gadjah Mada University. Poster presentation, WONCA conference, Hong Kong.

2. Widyandana. 2009. First year medical student experiences in primary health care settings as a part of community based education program. Paper presentation - AMEA conference, Bandung, Indonesia.

3. Widyandana D, Majoor GD, Scherpbier AJJA. 2010. Comparison of three clinical environments for undergraduate clinical skills training program: availability of cases, facilities, and clinical supervisors. Awarded as best oral presentation in APMEC conference, Singapore. The abstract published in Medical Education Journal Supplements April 2010. 
4. Widyandana D, Majoor GD, Scherpbier AJJA. 2010. Integrating skills training in skills laboratory and primary health care settings to prepare medical students entering hospital clerkship. Poster presentation in APMEC conference, Singapore.

5. Widyandana D, Majoor GD, Scherpbier AJJA. 2010. Clinical skills training in primary care settings successfully improve students' preparedness for clinical work. Oral presentation in OTTAWA conference, Miami, Florida.

6. Widyandana D, Majoor GD, Scherpbier AJJA. 2010. Transfer of medical students' clinical skills learned in a clinical laboratory to the care of real patients in the clinical setting: the challenges and suggestions of students in a developing country. Educ Health 23(3):1-6.

7. Widyandana D, Majoor GD, Scherpbier AJJA. 2011. Comparison of three clinical environments for pre-clinical clinical skills training. Med Teach Online: 1-5. (DOI:10.3109/0142159X.2011.558141).

8. Widyandana D, Majoor GD, Scherpbier AJJA. 2011. Effects of partial substitution of preclinical skills training by attachments to primary health care centers: An experimental study. MedTeach 33(6):e313-337.

9. Widyandana, Kristina TN. 2010. Developing community based education (CBE) program in primary health care $(\mathrm{PHC})$ : focusing on skills training. Pre-conference workshop at SEARAME international conference, Jakarta, Indonesia.

10. Widyandana D. 2010. Developing training for simulated patient's. Interactive workshop using video. Pre-conference workshop at SEARAME international conference, Jakarta, Indonesia.

11. Widyandana D. 2010. Teaching medical student's in primary health centers: a qualitative study on patients' perspective. Short-communication - oral presentation in SEARAME international conference, Jakarta, Indonesia.

12. Widyandana D. 2010. Comparison of four pre-clinical skills training methods: to improve student's active participation and clinical reasoning abilities. Poster presentation - oral presentation in SEARAME international conference, Jakarta, Indonesia.

13. Widyandana D. 2011. Comparing clinical attachments in primary and secondary health center to prepare medical students entering clinical rotation: a quantitative study. Oral presentation in WONCA conference, Cebu, Philippines.

14. Widyandana D, Majoor GD, Scherpbier AJJA. Patients' appreciation of pre-clinical students' performance in primary health care centers in Indonesia. Submitted.

15. Widyandana D, Majoor GD, Scherpbier AJJA. Students' experiences in early clerkships after preparatory attachments to primary health care centers: a qualitative study. Submitted. 


\section{LIST OF ABBREVIATIONS}

$\begin{array}{ll}\text { CBC } & =\text { Competence-Based Curriculum } \\ \text { CI } & =\text { Confident Interval } \\ \text { DOPS } & =\text { Direct Observation of Procedural Skills } \\ \text { DREEM } & =\text { Dundee Ready Education Environment Measure } \\ \text { ECE } & =\text { EarlyClinical Experience } \\ \text { FGD } & =\text { Focus Group Discussion } \\ \text { FM-GMU } & =\text { Faculty of Medicine at Gadjah Mada University } \\ \text { GMC } & =\text { General MedicalCouncil } \\ \text { GP } & =\text { General Practitioner } \\ \text { Mini-CEX } & =\text { Mini-Clinical Evaluation Exercise } \\ \text { NPT } & =\text { NotPrimary CareTrained } \\ \text { OSCE } & =\text { Objective Structured Clinical Examination } \\ \text { PHC } & =\text { Primary Health Care } \\ \text { PHPO } & =\text { Preparation for Hospital Practice Questionnaire } \\ \text { PT } & =\text { Primary CareTrained } \\ \text { SAP } & =\text { Students'Academic Self-Perception } \\ \text { SHC } & =\text { Secondary Health Care } \\ \text { SPA } & =\text { Students'Perception of Atmosphere } \\ \text { SPL } & =\text { Students'Perception of Learning } \\ \text { SPT } & =\text { Students'Perception ofTeaching } \\ \text { SSP } & =\text { Social Self-Perception } \\ \text { THC } & =\text { TertiaryHealth Care } \\ \text { WFME } & =\text { World Federation of Medical Education } \\ & \end{array}$

